\title{
Costa Rica: 2011 Article IV Consultation - Staff Report; Informational Annex; Public Information Notice, Press Release, and Statement by the Executive Director
}

Under Article IV of the IMF's Articles of Agreement, the IMF holds bilateral discussions with members, usually every year. In the context of the 2011 Article IV consultation with Costa Rica, the following documents have been released and are included in this package:

- $\quad$ The staff report for the 2011 Article IV consultation, prepared by a staff team of the IMF, following discussions that ended on April 12, 2011, with the officials of Costa Rica on economic developments and policies. Based on information available at the time of these discussions, the staff report was completed on May 11, 2011. The views expressed in the staff report are those of the staff team and do not necessarily reflect the views of the Executive Board of the IMF.

- Informational Annex to the Staff Report of May 11, 2011.

- $\quad$ The Public Information Notice

- The Press Release

- $\quad$ A Buff statement by the Executive Director

The policy of publication of staff reports and other documents allows for the deletion of market-sensitive information.

Copies of this report are available to the public from

International Monetary Fund • Publication Services $70019^{\text {th }}$ Street, N.W. • Washington, D.C. 20431

Telephone: (202) 623-7430 • Telefax: (202) 623-7201

E-mail: publications@imf.org Internet: http://www.imf.org

Price: $\$ 18.00$ a copy

\section{International Monetary Fund Washington, D.C.}




\section{INTERNATIONAL MONETARY FUND}

\section{COSTA RICA}

\section{STAFF REPORT FOR THE 2011 ARTICLE IV CONSULTATION}

May 11, 2011

\section{KEY ISSUES}

Near-term challenges: The rise in commodity prices and abundant global liquidity pose risks for the inflation outlook and for macroeconomic policy more generally. Maintaining the exchange rate band with the nominal rate at the most appreciated end is complicating further macroeconomic management. A well coordinated policy response comprising a tightening of the fiscal stance, greater exchange rate flexibility and watchful monitoring of inflation pressures is warranted.

Fiscal sustainability: Under staff projections, the authorities' fiscal plans would result in a gradual decline in the fiscal deficit and a moderate but steady rise in the public debt ratio (to 46 percent of GDP by 2016). The strategy is anchored on an important tax reform proposal under consideration by the Legislative Assembly. Although borrowing constraints are not likely to be binding in the near term, this strategy entails risks over the medium term. More ambitious fiscal consolidation targets centered on strict expenditure restraint would be advisable.

Monetary policy framework: The authorities have made progress in monetary control recently, and reiterated their commitment to transition to an inflation targeting regime. Delays in eliminating the exchange rate band could undermine the credibility of the process.

Financial system: The financial system remains sound, although there is scope to further strengthen supervision and regulation. Seeking approval of legislation enhancing consolidated supervision, establishing a deposit insurance system and strengthening the resolution framework should receive higher priority. 
Approved By

Miguel Savastano (WHD) and

Dominique Desruelle (SPR)
Discussions took place in San José during March 28 April 12, 2011. The staff team comprised Messrs. Piñón (head), Morra, Ms. Ustyugova (all WHD), Mr. Llaudes (SPR) and Mr. Delgado (Regional Resident Representative). Messrs. Pérez Verdía and Gramajo (both OED), participated in the policy discussions.

\section{CONTENTS}

BACKGROUND 4

POLICY DISCUSSIONS
A. Near-term Policy Mix 7
B. Safeguarding Fiscal Sustainability 8
C. Monetary and Exchange Rate Policies 12
D. Financial Sector 13

STAFF APPRAISAL 15 BOXES

1. Revenue Mobilization Strategy ___ 9

2. Risks To Fiscal Sustainability ___ 10

3. Main Recommendations of the 2008 FSAP Update - Status ___ 14

\section{FIGURES}

1. Recent Economic Developments ___ 17

2. External Developments ___ 18

3. Reserve Coverage in International Perspective___ 19

4. Fiscal Developments _ 20

5. Comparative Financial Soundness Indicators __ 21

6. Bank Deposits and Credit __ 22

7. External Debt Sustainability: Bound Tests___ 34

8. Public Debt Sustainability: Bound Tests _ 36 


\section{TABLES}

1. Selected Economic Indicators 23

2. Balance of Payments 24

3. Central Government Balance (In billions of colones) __ 25

4. Central Government Balance (In percent of GDP) _ 26

5. Combined Public Sector Operations (In billions of colones) __ 27

6. Combined Public Sector Operations (In percent of GDP) __ 28

7. Monetary Survey _ 29

8. Indicators of External Vulnerability __ 30

9. Medium-Term Framework___ 31

10. Banking Sector Indicators __ 32

11. External Debt Sustainability Framework, 2006-16 __ 33

12. Combined Public Sector Debt Sustainability Framework, 2006-16 _ 35 


\section{BACKGROUND}

1. Costa Rica weathered the global crisis well, but its fiscal position weakened considerably. The authorities' response to the crisis consisted of a supportive fiscal stance and increased recourse to external resources, (including through a 15-month precautionary Stand-By arrangement with the Fund that expired in July 2010). In the event, the output loss was moderate, the balance of payments adjustment was orderly, and the financial system remained sound. The fiscal position, however, deteriorated significantly as a result of much lower-than-expected revenues and higher-than-envisaged increases in current expenditure.
2. The administration that took office in May 2010 has proposed a tax reform to reduce the fiscal deficit. President Laura Chinchilla is committed to improve law enforcement, education, and infrastructure. In January 2011, the administration submitted a tax reform proposal to the Legislative Assembly. The government has also taken steps to improve tax administration.

3. Exchange system and statistics. Costa Rica has accepted the obligations of Article VIII, sections 2, 3, and 4. Its exchange system is free of restrictions on the making of payments and transfers for current international transactions. Data provision is broadly adequate for surveillance.

\section{RECENT ECONOMIC DEVELOPMENTS}

4. Economic growth resumed in 2010, while inflation remained subdued (Figure 1). Following a 1.3 percent decline in 2009, real GDP grew by 4.2 percent in 2010, initially led by a recovery in inventories and public consumption and later by private consumption. Annual inflation increased from 4 percent in 2009 to 4.6 percent at endMarch 2011 (within the 4-6 percent official target range). Core inflation also increased moderately (to 4 percent). More recently, the rise in international food and fuel prices has pushed inflation expectations further above the ceiling of the inflation target range.

5. The external current account deficit widened in 2010, but private capital inflows recovered (Figure 2). Following a sharp contraction of trade, export growth rebounded in 2010 (6.5 percent) but was outpaced by the growth rate of imports (19.6 percent), raising the external current account deficit to 3.6 percent of GDP (2 percent in 2009). The surplus in the capital account also increased significantly, as the private sector deleveraging observed in 2009 ended, and net public sector inflows increased (including a US\$500 million loan from the World Bank). As a result, the overall balance of payments recorded a surplus of over US $\$ 550$ million ( $1 \frac{1}{2}$ percent of GDP) during the year.

Private Capital Account (In millions of U.S. dollars)

\begin{tabular}{lccc}
\hline & 2009 & 2010 & Change \\
\hline Private capital account & 291 & 1,681 & 1,390 \\
FDI & 1,347 & 1,450 & 103 \\
Non-FDI flows & $-1,056$ & 231 & 1,287 \\
Of which: Banking sector & -727 & 136 & 863 \\
Of which: Nonfinancial private sector & -329 & 95 & 423 \\
\hline
\end{tabular}

Source: Fund staff based on Central Bank of Costa Rica. 
6. The exchange rate appreciated and reached the bottom of the band in late 2010 . From mid-2009 to April 2011, the colón appreciated by some 15 percent vis-à-vis the U.S. dollar (14 percent in real effective terms). The colón reached the appreciated end of the exchange rate band in December 2010, and has remained within 2 percent of the floor since then. The appreciation pressures stemmed from higher private capital inflows, and were supported by some portfolio rebalancing toward colón-denominated assets.

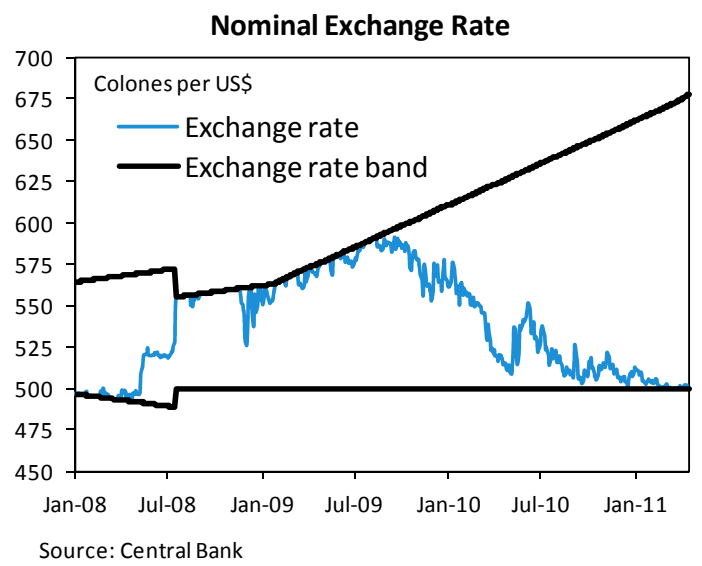

7. The central bank adopted measures to contain the appreciation pressures. Starting in August 2010, it has lowered the policy interest rate by a total of 250 basis points (to 6.5 percent); and in September 2010 it launched a 16-month program of foreign exchange purchases for a total of US\$600 million (Figure 3 ). The cumulative purchases under the program reached the announced US\$600 million target in April 2011.

8. The authorities kept the inflation target range for 2011 unchanged at 46 percent, and adopted measures to enhance monetary control. The increased inflation risks led the central bank to postpone a planned reduction in the inflation target to 35 percent. The authorities also established a deposit facility for banks that, combined with a previously existing lending facility, created a corridor for short-term interest rates, and introduced new instruments to mop up excess liquidity. These measures have stabilized short-term interest rates at the bottom of the corridor.

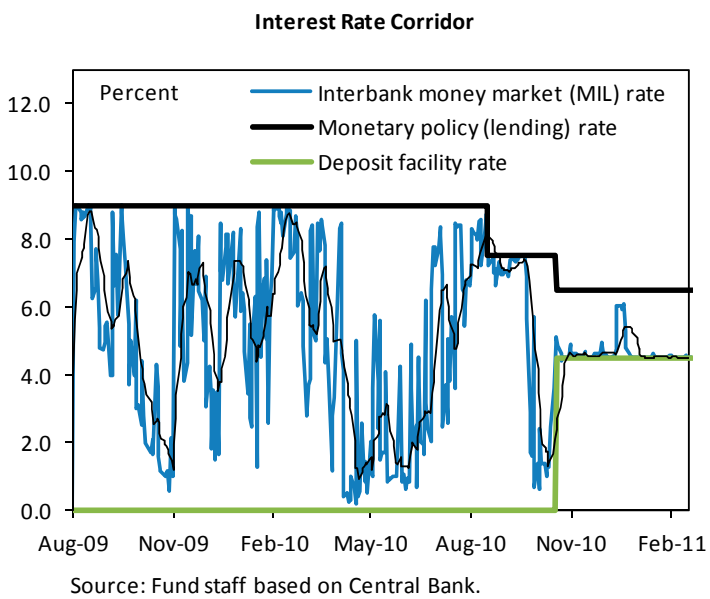

9. The fiscal deficit continued to widen (Figure 4). Government spending continued to increase in 2010, including in wages and current transfers; and the consolidated public sector deficit rose to $5 \frac{1}{2}$ percent of GDP (4 percent in 2009). Public sector debt at end2010 reached 39.4 percent of GDP, up from 36 percent in 2008.

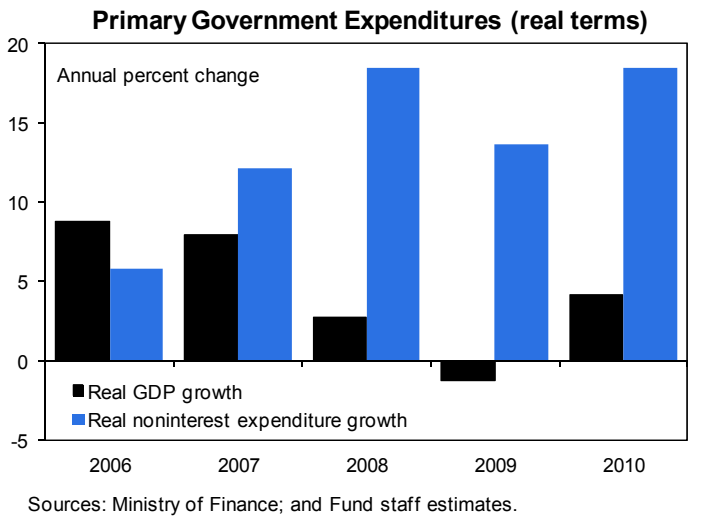

10. The banking sector remained resilient. Although banks' profitability declined (the 
return on equity fell from 14.3 percent in December 2008 to 8.3 percent in December 2010), the change was largely attributable to the economic slowdown and other transitory effects. Moreover, capitalization and liquidity levels remain adequate. Nonperforming loans have stabilized below 2 percent of total loans (Figure 5). Credit growth to the private sector remained subdued in 2010, but has started to pick up in 2011. The share of bank loans and deposits denominated in U.S. dollars continued to decline, although the latter remains above pre-crisis levels. (Figure 6).

Effective Capital Adequacy Ratio

\begin{tabular}{lrrr}
\hline & 2008 & 2009 & 2010 \\
\hline CAPDR 1/ & 14.4 & 15.5 & 16.1 \\
Costa Rica & 15.1 & 15.9 & 16.4 \\
\hline
\end{tabular}

Source: Surpervisory authorities, and Fund staff estimates.

Notes:

1/ Regional unweighted average.

\section{MACROECONOMIC OUTLOOK AND RISKS}

11. The economic outlook is generally positive. Supported by the global recovery and strong inflows of foreign direct investment (FDI), real GDP is projected to grow by 4.3 percent in 2011 and stabilize at $41 / 2$ percent over the medium term (somewhat below pre-crisis rates). Higher global food and fuel prices and the one-off impact of the tax reform (expected to be approved in the second half of 2011) would push inflation above 7 percent in 2011; thereafter inflation is projected to fall gradually to about 4 percent. The external current account deficit is expected to increase to 4.8 percent of GDP in 2011 and stabilize at about 5.2 percent over the medium term, and be fully financed by strong FDI and other capital flows.

12. Risks to the medium-term outlook are somewhat tilted to the downside.

- Risks to the growth outlook appear balanced. Concerns about the strength of the global recovery are subsiding, while lax global financial conditions may induce further capital inflows and fuel domestic demand and activity growth.

- $\quad H i g h e r$ global commodity prices pose risks for the inflation outlook. Continued global price pressures could push headline inflation further above the official target range, which in the absence of corrective policies could ignite second round effects and keep inflation above the target range for a prolonged period of time.

- $\quad$ Fiscal policy's capacity to respond to adverse shocks will be limited. The government's fiscal strategy may result in a moderate increase in the public debt to GDP ratio, even after taking into account the revenues from the tax reform. There are also risks that the increase in public debt is higher than envisaged. 


\section{POLICY DISCUSSIONS}

13. Focus of the consultation. Discussions with the authorities centered on the appropriate policy mix at the current stage of the economic cycle; and medium-term reforms to: (i) ensure fiscal sustainability; (ii) improve the effectiveness of monetary policy; and (iii) increase the resilience of the financial system.

\section{A. Near-term Policy Mix}

14. There was broad agreement that containing second round effects from higher global food and fuel prices is a key policy challenge. Although inflation has remained subdued, staff highlighted the upward risks to the inflation outlook stemming from lags in the transmission mechanism and entrenched backward-looking indexation, including for public sector wages. Those factors contributed to a large pass-through to inflation in Costa Rica during the global price shock of 2007-08. The authorities were of the view that inflation risks would be lower this time around because the surge in commodity prices is taking place when there is still slack in the economy.

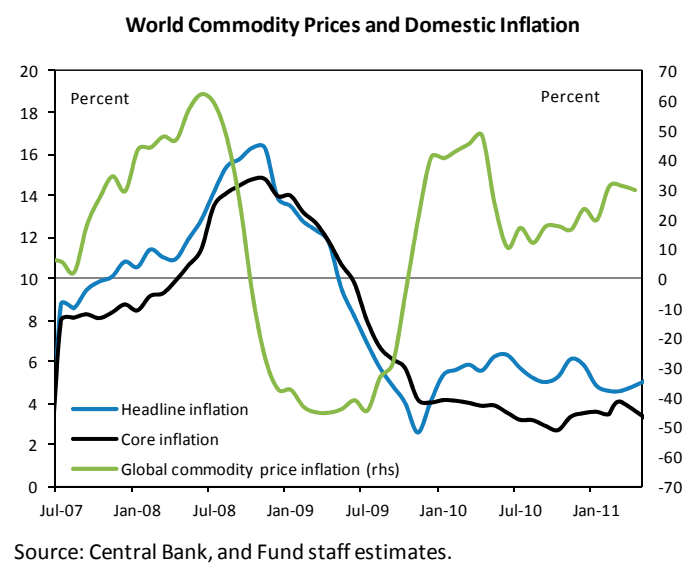

15. Continued capital inflows also present risks to the inflation outlook. Lax global financial conditions will remain a push factor for capital flows to emerging economies. Staff noted that, as long as the exchange rate band remains in place, those inflows would put pressure on the Central Bank's sterilization capacity and, in the end, result in higher inflation and a real appreciation of the colón.

16. Staff encouraged the authorities to take prompt action to preserve the significant gains on the inflation front attained in recent years. Concretely, staff recommended:

- $\quad$ Restraining domestic demand growth through further fiscal effort. Staff noted that the fiscal outturn projected for 2011 (a consolidated public sector deficit of about $51 / 2$ percent of GDP) was too expansionary given the rebound in private domestic demand. The authorities agreed, in principle, and noted that a recent presidential directive freezing employment levels in the central administration and reducing operational expenditures below the levels contemplated in the budget would generate some savings. However, additional expenditure reducing measures were not regarded as viable.

- $\quad$ Standing ready to raise interest rates before core inflation increases. Staff underscored that, if fiscal policy remains loose, efforts to attain the inflation target would place a considerable burden on monetary policy. The authorities indicated their intentions to evaluate the monetary policy stance at the first signs of secondround effects on inflation. However, they 
were of the view that those inflationary pressures are not likely to materialize for a while.

- $\quad$ Allowing the nominal exchange rate to appreciate. The authorities indicated they remained committed to a more flexible exchange arrangement, but considered that conditions were not propitious for the elimination of the exchange rate band, as it could result in a large appreciation of the colón. They argued that given current loose global financial conditions, macroeconomic policy tools may be insufficient to fend off a large undershooting. Staff noted that the risk of a large or prolonged undershooting of the nominal exchange rate following the termination of the band could be mitigated through a tighter fiscal stance and sterilized

\section{B. Safeguarding Fiscal Sustainability}

18. The mission developed a scenario incorporating the government's fiscal plans. The scenario envisages an increase in government revenues of 3 percentage points of GDP in the next five years (mainly as a result of the proposed tax reform and improvements in tax administration, Box 1) and an increase in expenditures of about 1 percent of GDP (reflecting planned spending in the areas of security, education and infrastructure ${ }^{1}$ ). With these assumptions, the consolidated public sector deficit (central government deficit) would decline to about $4 \frac{1}{4}$ percent of GDP (33/4 percent of GDP) by 2016, while the public debt to GDP ratio would rise to about 46 percent of GDP. The

1 The Legislative Assembly is expected to approve a constitutional amendment mandating an increase in education spending to 8 percent of GDP by 2014 (about 1 percent of GDP above the current level). intervention. The authorities indicated their preference for waiting until temporary appreciation pressures subside rather than doing away with the bands.

\section{Staff encouraged the authorities to} develop a strategy to reduce backwardlooking indexation practices. In particular, it recommended to start using forward-looking measures of inflation (such as the mid-point of the official inflation target) to adjust prices and wages set by the government (including the minimum wage). The authorities agreed that forward-looking measures would be preferable but noted that any changes to current practices would require building consensus and, in some cases, changing legislation, both of which were likely to take some time.

authorities thought that the scenario made too conservative assumptions regarding the gains from the tax reform and were of the view that the fiscal deficit would decline more rapidly to debt stabilizing levels.

19. The mission encouraged the authorities to adopt more ambitious fiscal consolidation targets. It noted that Costa Rica had been able to respond effectively to the global crisis in large part because of the significant fiscal consolidation it had undertaken in the years prior to the crisis. Staff argued that a priority of fiscal policy should be to regain the capacity to respond in a similar way to future adverse shocks by placing the public debt to GDP ratio on a downward path, and bringing the ratio below 35 percent of GDP over the medium term. The authorities indicated that reducing the public debt ratio to pre-crisis levels would be challenging, but stressed that they will make 
every effort to keep the public debt at prudent levels, including through expenditure restraint.

\section{Box 1 Revenue Mobilization Strategy}

The Costa Rican government has developed a strategy to increase tax revenues over the medium term. The strategy comprises a tax reform and tax administration efforts, which the authorities expect to yield 21/2 percent of GDP and about 1 percent of GDP, respectively.

\section{A comprehensive tax reform proposal was submitted to the National Assembly in}

January 2011. The main measures contemplated in the bill include: replacing the 13 percent sales tax for a 14 percent full-fledged value-added tax (VAT); a significant broadening of the VAT base to include key services that are currently exempt (e.g. private education and health); reducing the basic consumption basket that will be exempt from the VAT; the introduction of a 15 percent tax rate on capital gains; increasing the tax rate on dividends (from 5 to 15 percent) and on interest received on exchange-traded securities, bank deposits and public debt securities

\begin{tabular}{|lc|}
\hline \multicolumn{2}{|c|}{ Tax reform proposal } \\
\hline Measures & $\begin{array}{c}\text { Expected yield * } \\
\text { (in percent of GDP) }\end{array}$ \\
\hline Total & $\mathbf{2 . 5}$ \\
Value added tax & 1.7 \\
Broadening of tax base & 1.4 \\
Of which: Reduction of basic consumption basket & 0.7 \\
Of which: Taxation of services & 0.8 \\
Increase in tax rate (from 13 to 14 percent) & 0.3 \\
Income tax & 0.6 \\
Broadening of tax base & 0.6 \\
Increases in tax rates & 0.1 \\
Excise taxes and other & $\mathbf{0 . 2}$ \\
\hline Source: Fund staff based on Ministry of Finance. \\
* Estimated by the Ministry of Finance. \\
\hline
\end{tabular}
(from 8 to 15 percent); introducing a 15 percent tax rate on external payments made to toptier banks and other institutions; and raising selective taxes on vehicles and property transfer taxes. The authorities' estimates of the yield of the components of the proposed reform are shown in the table.

The proposed tax reform would improve the efficiency and equity of Costa Rica's tax system. Adoption of the proposed measures would require modernizing the method to determine the VAT liability, bringing it in line with international practices. It would also increase the equity of the system by eliminating exemptions currently benefiting the higher income segments of the population. The authorities estimate that 60 percent of the additional revenue would be generated from households in the top 20 percent income bracket.

The government's strategy also contains measures to reduce tax evasion. Planned actions include increasing tax compliance controls by 20 percent, fostering the use of debit and credit card transactions, establishing reference values for a set of imported products, and broadening the tax regime for small contributors. 


\section{Box 2 Risks to Fiscal Sustainability}

Following an important decline through 2008, Costa Rica's public debt to GDP ratio rose in the aftermath of the global crisis. From end-2008 to end-2010, the public debt to GDP ratio increased by about 4 percentage points, to near 40 percent.

The policies envisaged by the current government would not stabilize the public debt to GDP ratio. The staff's scenario discussed with the authorities, which assumes that the tax reform is approved in the second-half of 2011, would result in an increase in the public debt to GDP ratio of more than 6 percentage points between 2010 and 2016. Even though the scenario assumes significant increases in tax collection, the expenditure path would leave the fiscal deficit above debt-stabilizing levels. ${ }^{2}$

The risks that the public debt to GDP ratio rises faster than in the baseline scenario are high. Results from a stochastic public debt sustainability exercise, based on an estimated fiscal reaction function, show that, by end-2016, the median public debt ratio could be in the range between 50 percent of GDP (panel estimates) and 57 percent (time series estimates). These results illustrate the challenges that the authorities will confront to maintain the public debt close to the deterministic trajectory of the baseline scenario under their planned fiscal policies.

Stochastic public debt analysis (time series)

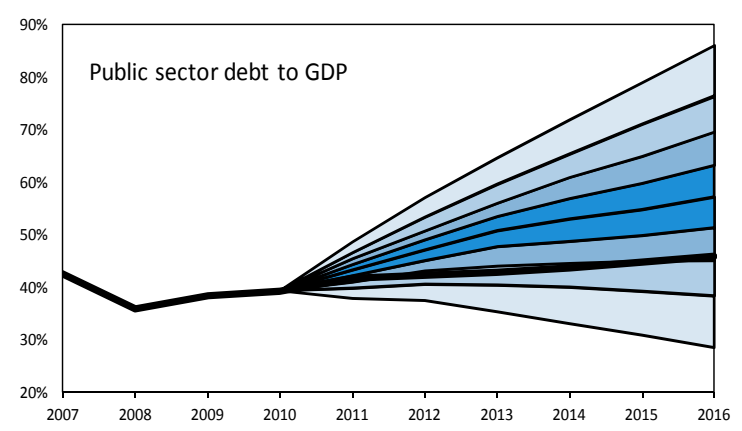

Source: Fund staff estimates
Stochastic public debt analysis (panel data)

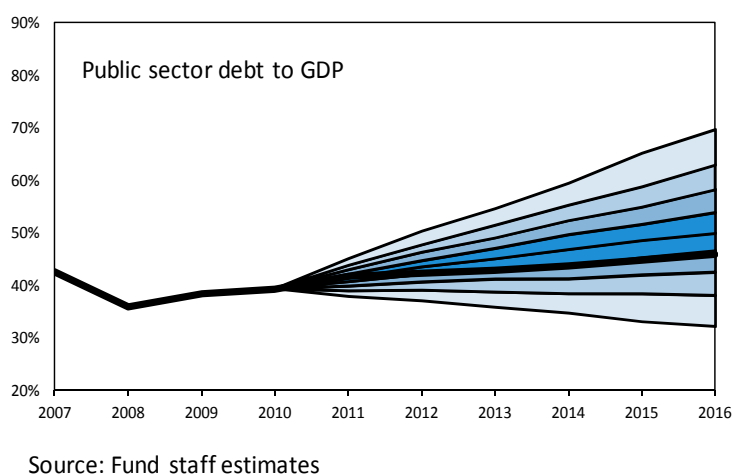

${ }^{2}$ The authorities' estimate of the revenue yield of the tax reform is higher than staff's (see Box 1), reducing the deficit to debt-stabilizing levels. 
20. There was agreement that the approval of the proposed tax reform was critical for fiscal sustainability. A significant increase in government revenues is necessary to contain debt dynamics, given the planned expenditure path (Box 2). Staff noted that the revenue-enhancing emphasis of the proposed reform was appropriate given Costa Rica's relatively low revenue-to-GDP ratio. The expected broadening of the tax base and the emphasis placed on improving the equity of the tax system also are commendable. While the tax reform is facing some opposition in the Legislative Assembly, the authorities expressed confidence about its approval, highlighting that the private sector and political parties are cognizant of the need to increase public revenues.
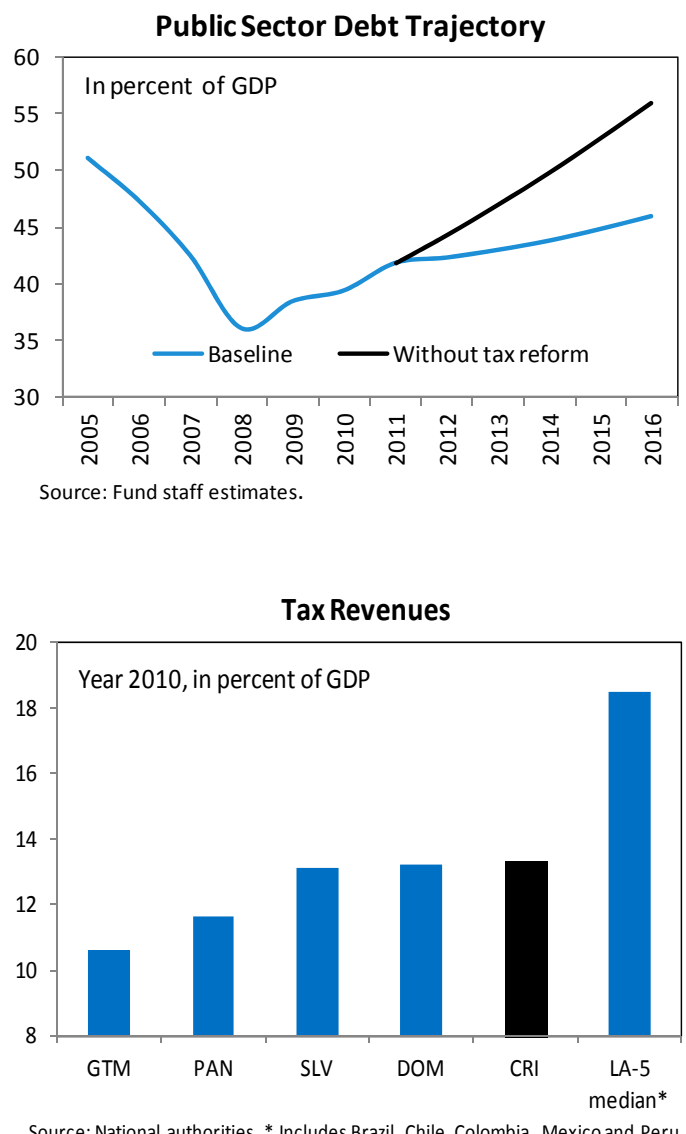

21. A strategy to reduce government expenditures in percent of GDP over the medium term is necessary. Although capital expenditure has remained broadly stable as a share of GDP in recent years, current government expenditures, including the wage bill, have increased sharply, and have reached levels that are high compared to countries of similar level of income and government revenues. The mission noted that the recent directive to freeze vacancies and reduce operational expenditures (vis-à-vis the budget) in 2011 was an important first step, but stressed that it would not be sufficient to reduce current expenditures' share in GDP. Staff argued that a medium-term expenditure framework that keeps current expenditure growth below the (projected) growth rate of nominal GDP for several years was necessary to lower the share of current expenditures to GDP and regain fiscal space.

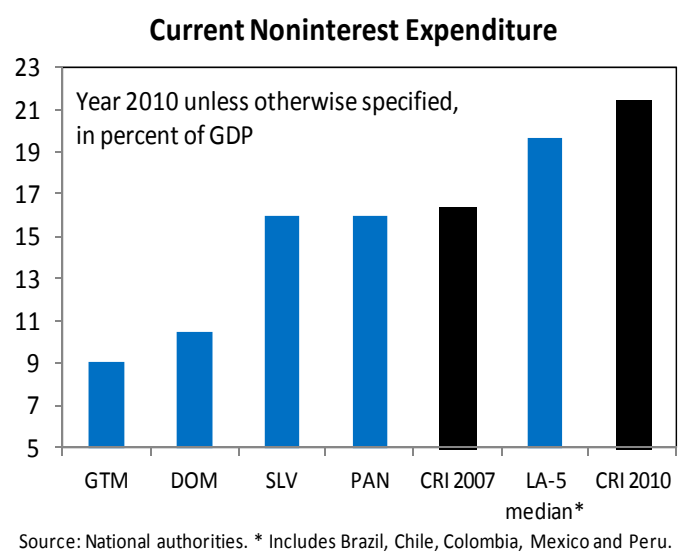

22. The mission welcomed the planned improvements in tax administration. Staff and the authorities concurred that there is substantial scope to strengthen tax administration and reduce tax evasion, and that the improvements in these areas would contribute importantly to the fiscal consolidation strategy. In this connection, staff welcomed the adoption of a new 
information system by the tax administration agency, which would help increase information crosschecks and tax compliance controls. Staff estimated that improved tax administration would generate additional revenues of about $1 / 2$ percent of GDP over the next five years. The authorities, however, considered that the gains would be significantly larger.
23. Other reforms to strengthen the fiscal frameworks also were discussed. There was broad agreement that, once fiscal consolidation was firmly underway, it would be desirable to develop fiscal rules with countercyclical elements. Reforms aimed at lessening budget rigidities, such as revenueearmarking, would also be desirable.

\section{Monetary and Exchange Rate Policies}

24. The mission encouraged the authorities to speed up the transition to an inflation targeting framework. The mission acknowledged the important steps taken in recent years to modernize the monetary policy framework (including the announcement of an official inflation target and the widening of the exchange rate band). However, it noted that a prolonged transition process risks losing credibility. To accelerate the transition, staff recommended:

- Increasing exchange rate flexibility. Staff underscored that moving toward a more flexible exchange rate regime, preferably by eliminating the band, would clarify the primacy of the inflation objective, help anchor inflation expectations, and enhance the transmission mechanism between policy rates and market rates. The authorities restated their intention to eliminate the exchange rate band before the adoption of full-fledged inflation targeting, but considered that the present juncture was not appropriate to take such step (ף15).

- $\quad$ Phasing out the interest rate corridor. There was agreement that the interest rate corridor established in October 2010 had enhanced monetary control, and that it would be advisable to deepen the reform by adopting a single policy rate. In line with this, the authorities indicated that they plan to narrow the corridor for short-term interest rates and establish the mid-point of such corridor as the benchmark policy rate.

- $\quad$ Recapitalizing the central bank. Staff argued that a stronger capital base for the central bank would help insulate monetary policy decisions from balance sheet considerations. The authorities indicated that they were examining options to recapitalize the central bank but considered that fiscal space in the short run was too tight to make significant progress in this area.

25. Notwithstanding the recent appreciation, the exchange rate seems broadly in line with medium-term fundamentals. Exchange rate assessments based on the standard methodologies suggest an overvaluation of the colón in the order of 2-6 percent, well within the margin of error. Favorable prospects for foreign direct investment, which are expected to cover the non-interest current account deficit over the medium term, are key for this result. Nonetheless, staff underscored that a fiscal consolidation strategy centered on 
expenditure restraint would help mitigate the risks of an excessive appreciation of the colón. In addition, there was agreement that continued efforts to reduce the costs of doing business and increase efficiency would be beneficial for competitiveness.

\section{Financial Sector}

26. While acknowledging that the financial system had weathered the crisis well, the mission discussed enhancements to banking sector supervision and regulation. It noted that the legal framework remained weak and that progress in implementing the recommendations from the 2008 FSAP had been slow (Box 3). The mission stressed the importance of seeking congressional approval of the legislation submitted in 2004 and 2010 to enhance consolidated supervision, establish a deposit insurance system and strengthen the bank resolution framework. It noted that, while the financial system is sound, the measures were necessary to reduce risks to financial stability, as they would equip the regulatory and supervisory authorities with the tools and legal protections to take appropriate actions on a timely basis if a financial institution faces difficulties. The authorities reiterated their commitment to seek approval of the legislation, but indicated that the tax reform had the highest priority.

\section{The mission welcomed progress to} introduce risk-based supervision. It encouraged the authorities to supplement those efforts with enhancements of the regulatory framework (e.g., issuing norms on liquidity, operational, country and market risks) and further strengthen soundness classification. It also suggested that the authorities undertake periodic stress tests of
Real Exchange Rate Ass ess ment

(Percent deviation from estimated equilibrium)

$(+=$ overvaluation $)$

\begin{tabular}{ll}
\hline Macrobalance approach & 6 \\
ERER approach & 6 \\
External stability approach & 2 \\
\hline Source: Fund staff estimates &
\end{tabular}

financial institutions. The mission welcomed the plans to monitor systemic risk and introduce Basel III capital and liquidity buffers.

Supervisory Practices (Scale from 0 to 10, $10=$ Best International Practices)

\begin{tabular}{|l|c|c|c|c|c|c|c|c|}
\hline & CRI & DOM & SLV & GTM & HND & NIC & PAN & AVGE \\
\cline { 2 - 9 } & 4.8 & 5.7 & 4.2 & 5.4 & 4.5 & 3.8 & 4.7 & 4.7 \\
\cline { 2 - 9 } Risk-Based Supervision \\
Consolidated Supervision & 6.4 & 4.2 & 6.2 & 8.3 & 7.1 & 7.4 & 7.8 & 6.8 \\
\cline { 2 - 9 } Supervisory perimeter & 6.6 & 4.3 & 1.8 & 3.7 & 3.1 & 3.9 & 4.5 & 4.0 \\
\hline \hline TOTAL & 6.0 & 4.8 & 4.1 & 5.8 & 4.9 & 5.0 & 5.7 & 5.2 \\
\hline
\end{tabular}

Source: Fund staff based on supervisory authorities' responses to questionnaires.

COLOR CODE: Less than 10 percent above or below the regional avge Above regional average Below regional average

28. The authorities were encouraged to explore ways to level the playing field between public and private banks. Staff noted that long-standing regulatory distortions of the Costa Rican financial system have allowed public banks to benefit from state guarantees on all liabilities, and be exempt from taxation on their dollardenominated deposits and from contributions to the development finance system. In addition, the appointment of their directors falls outside the purview of the Superintendency of Financial Institutions (SUGEF). 


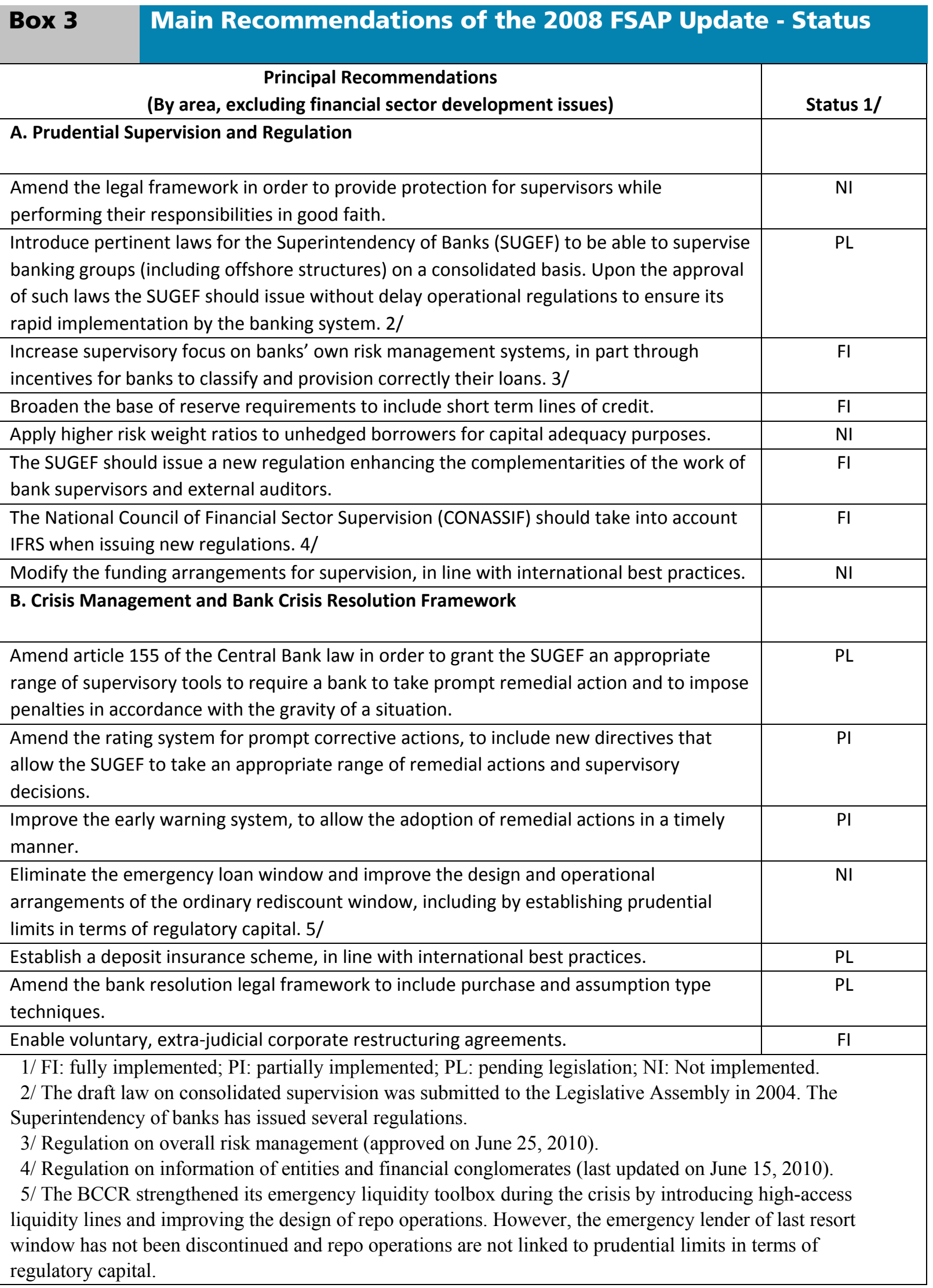


STAFF APPRAISAL

29. Costa Rica's recovery is firmly underway and its economic outlook is favorable. Real GDP is expected to grow by more than 4 percent in 2011 and by about $4 \frac{1}{2}$ percent over the medium term, supported by sizable and stable flows of foreign direct investment. However, a key challenge is to adopt more flexible and forward-looking macroeconomic policies.

30. The rise in world food and fuel prices and lax global financial conditions will present challenges. Higher commodity prices will put upward pressures on inflation and impact more severely the poorer segments of the population, while abundant global liquidity will continue to induce private capital inflows. A coordinated policy response to mitigate the risks posed by these external factors would be advisable. Such response should comprise a tighter fiscal stance than the one contemplated in the 2011 budget, the elimination of the exchange rate band, and readiness to tighten monetary policy before second round effects of the price shock materialize. Introducing forward-looking inflation measures in the indexation mechanisms controlled by the government also would be helpful.

31. Given the external environment, the fiscal stance envisaged for 2011 is too expansionary. Even assuming that the tax reform is approved and starts yielding revenues in 2011, the consolidated public sector deficit is projected to close the year at about $5 \frac{1}{2}$ percent of GDP, broadly the same as in 2010. The sustained recovery of private domestic demand and the sizable increase in public debt since 2008 would have called for a significant withdrawal of fiscal stimulus, as was recommended previously.

32. The proposed tax reform is sound and, if approved, will be key to safeguard fiscal sustainability. Broadening the tax base and improving the equity of the tax system are strong elements of the proposed reform. Planned efforts to strengthen tax administration also are appropriate and should be supplemented with mechanisms to make them permanent.

33. It would be advisable to set more ambitious targets for fiscal consolidation centered on expenditure restraint. The government's fiscal program may result in a gradual rise in the public debt ratio and carries risks. The authorities are encouraged to reconsider their fiscal program and set targets aimed at rebuilding the fiscal space used in recent years. These efforts should be anchored on a path that lowers the share of government expenditures (including the wage bill) on GDP.

34. The upgrading of the monetary policy framework should receive higher priority. Costa Rica's transition to an inflation targeting framework is taking too long and may compromise the central bank's credibility. Maintaining the exchange rate close to the appreciated end of the exchange rate band despite continued capital inflows could raise doubts about the primary objective of monetary policy and the authorities' commitment to transition to inflation targeting. The authorities are encouraged to consider an opportune time to abandon the exchange rate band and deploy an effective communication strategy to establish the 
primacy of the inflation target. Plans to narrow the corridor for short-term interest rates and establish the mid-point of such corridor as the policy rate are welcome.

35. Although the Costa Rican banking system remains sound, legislation to further strengthen supervision and prudential regulations has not yet been approved. The authorities are encouraged to seek support for the approval of the bills submitted in recent years to enhance consolidated supervision, establish a deposit insurance system and strengthen the resolution framework. In addition, the authorities should explore ways to level the playing field between public and private banks.

36. It is recommended that the next Article IV consultation take place on the standard 12-month cycle. 


\section{Figure 1. Costa Rica: Recent Economic Developments}

Output growth has resumed...

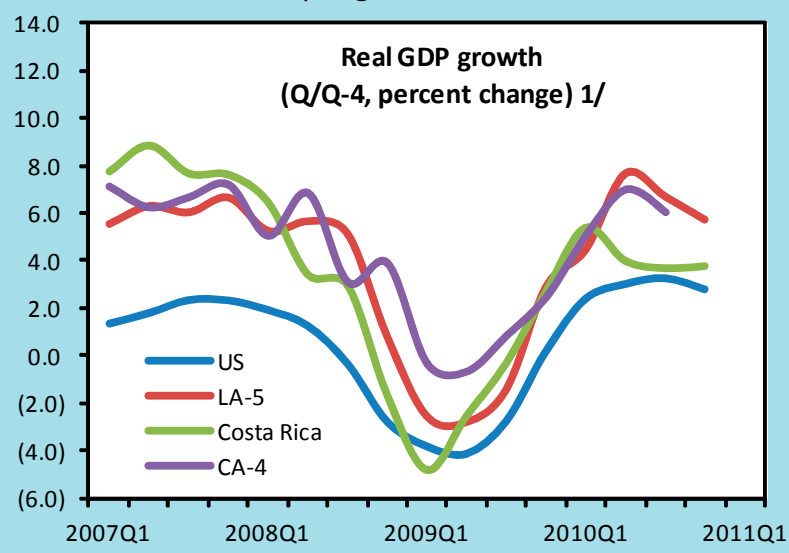

Growth is broad-based, but construction is lagging.

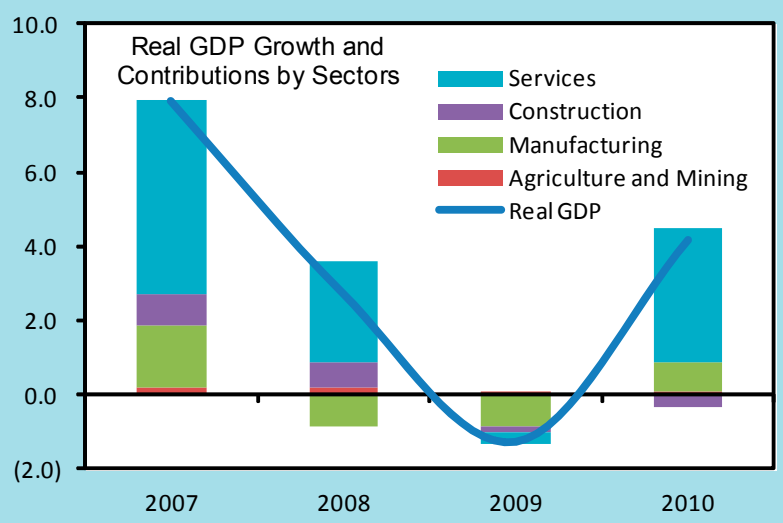

...but inflation remains within the target band.

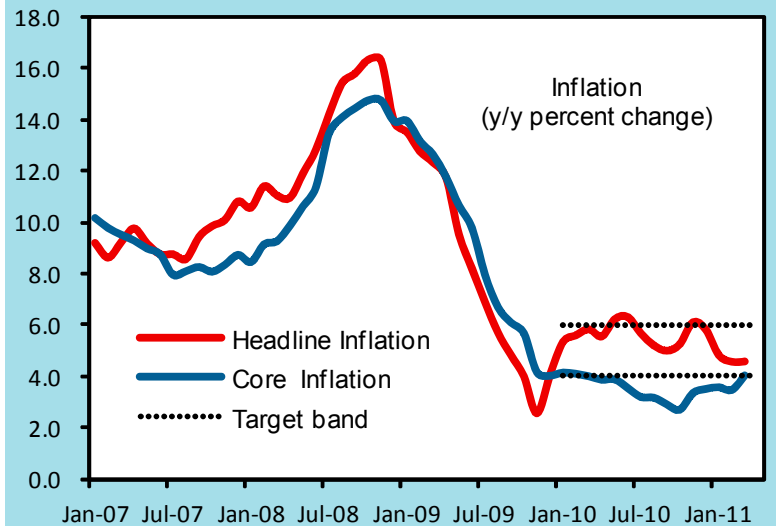

Sources: Country authorities; and Fund staff calculations.

1/ CA-4 includes median growth rates of Guatemala, Honduras, EI Salvador and Nicaragua. LA-5 includes median growth rates of Brazil, Chile, Colombia, Mexico and Peru.
... driven by domestic demand.

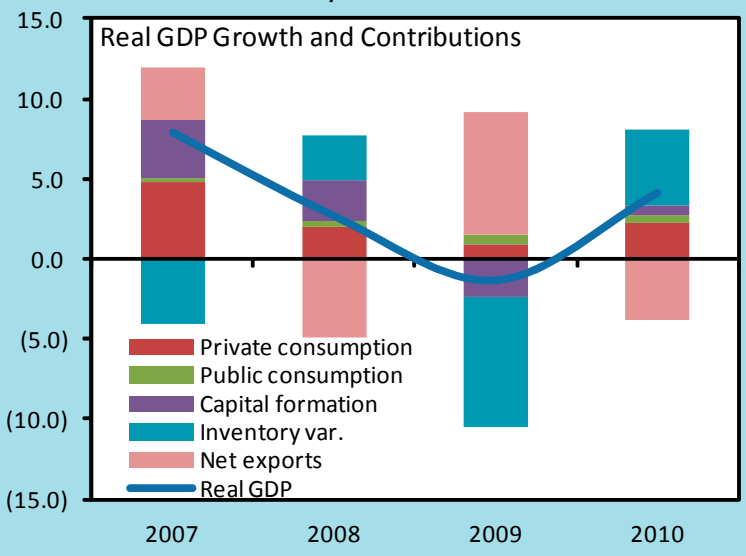

Food prices have increased...

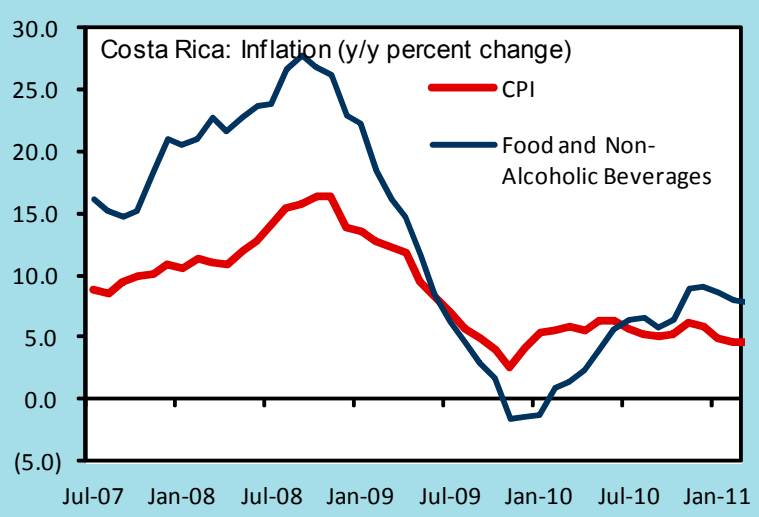

Inflation expectations have started to rise.

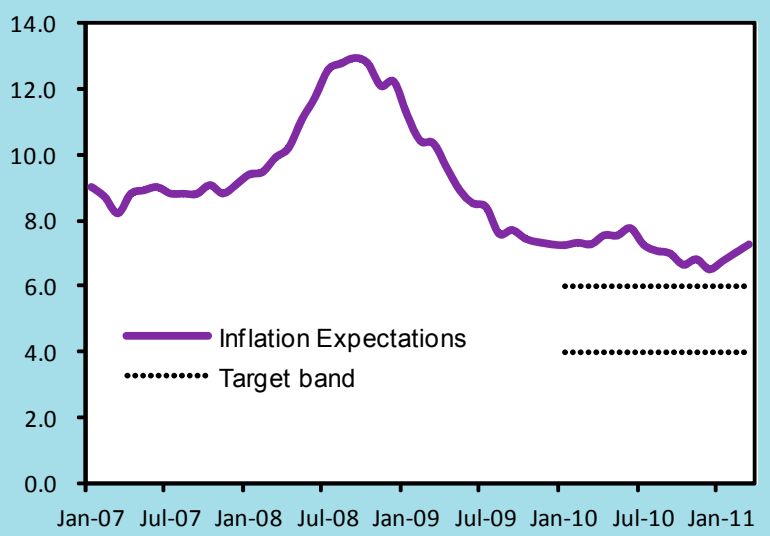


Figure 2. Costa Rica: External Developments

In 2010, the external current account deficit widened... ... and net capital inflows picked up...
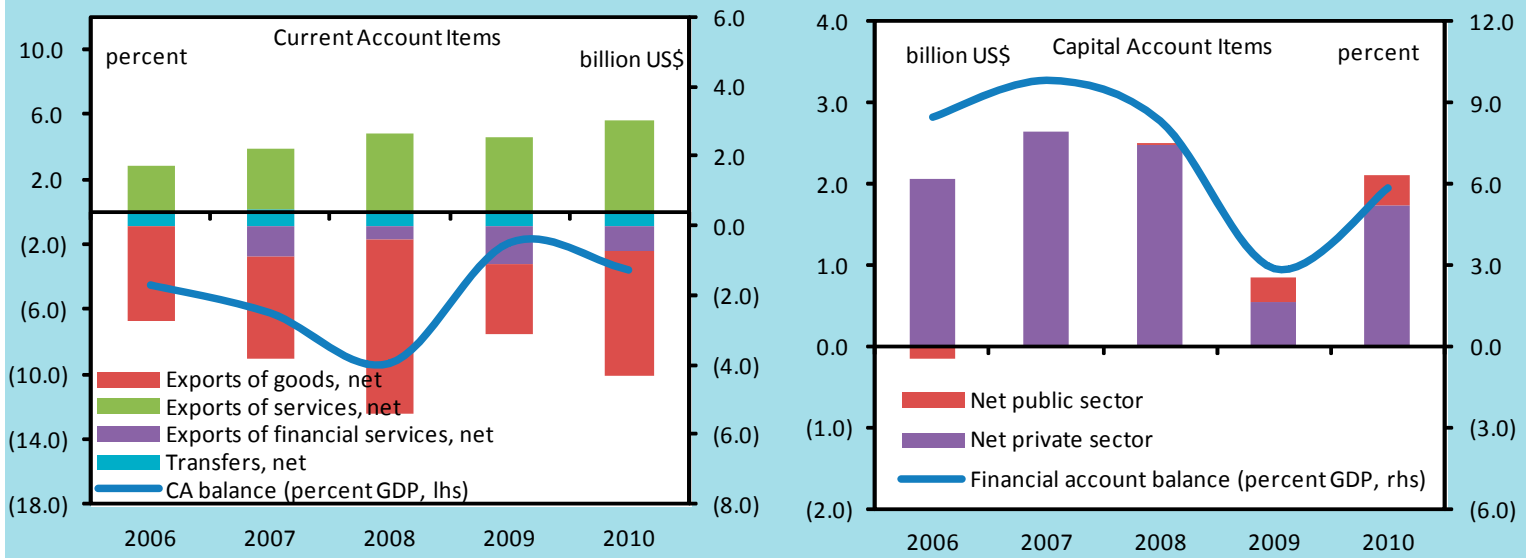

... as large FDI inflows were accompanied by other private inflows.

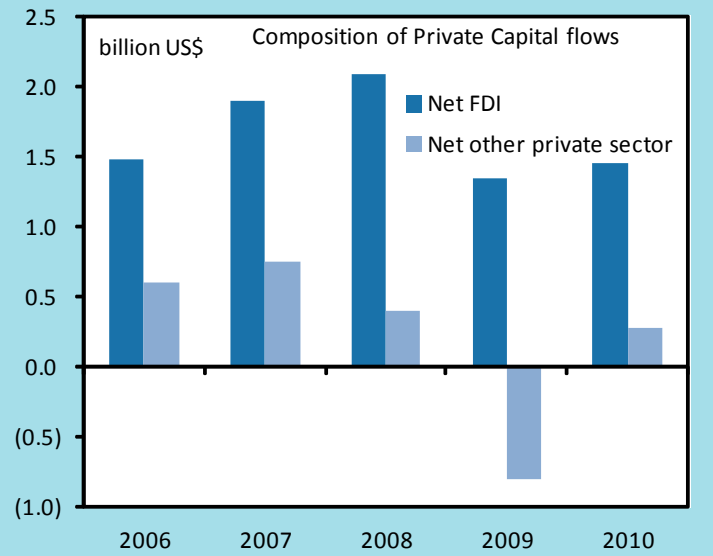

International reserves increased as the Central Bank launched a program to purchase foreign exchange.

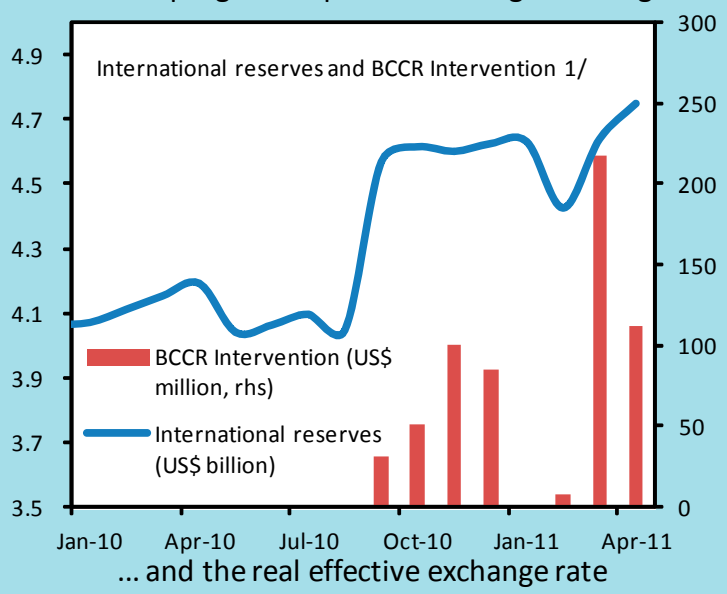
bottom of the band..
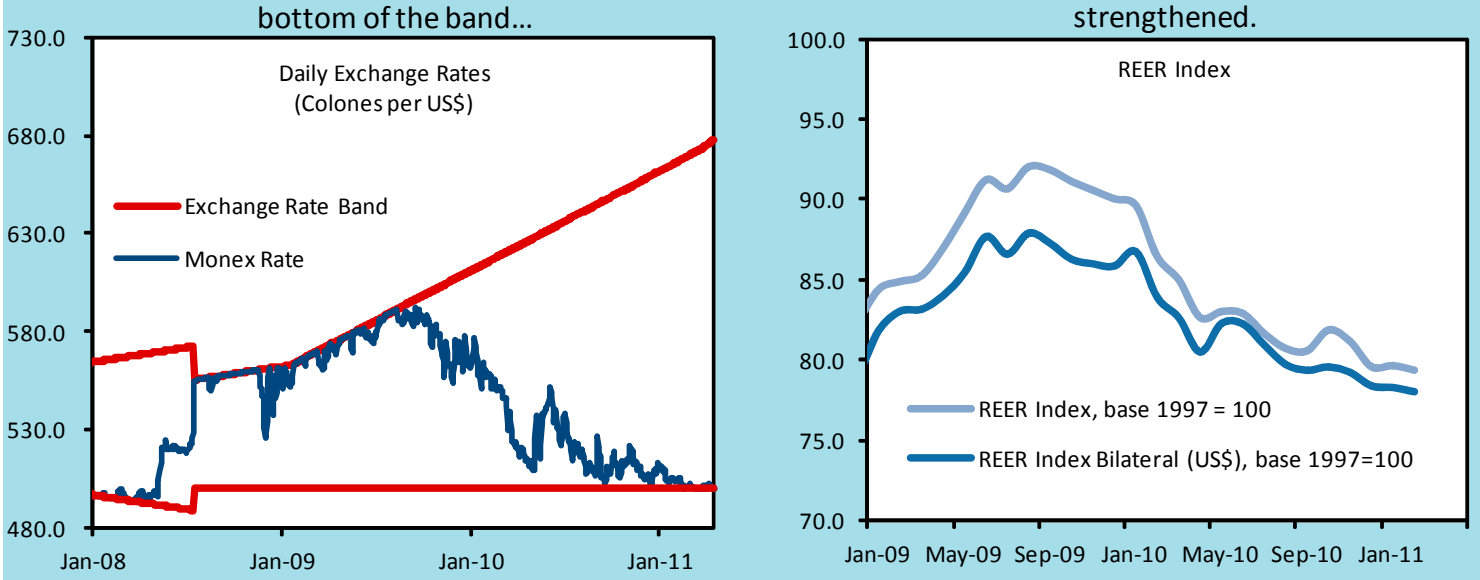

Sources: Country authorities; and Fund staff calculations.

$1 /$ The increase in international reserves of September 2010 reflects a US $\$ 500$ million disbursement from the World Bank. The decrease in international reserves of February 2011 reflects the amortization of a US $\$ 250$ million bond. 
Figure 3: Costa Rica: Reserve Coverage in International Perspective ${ }^{1}$
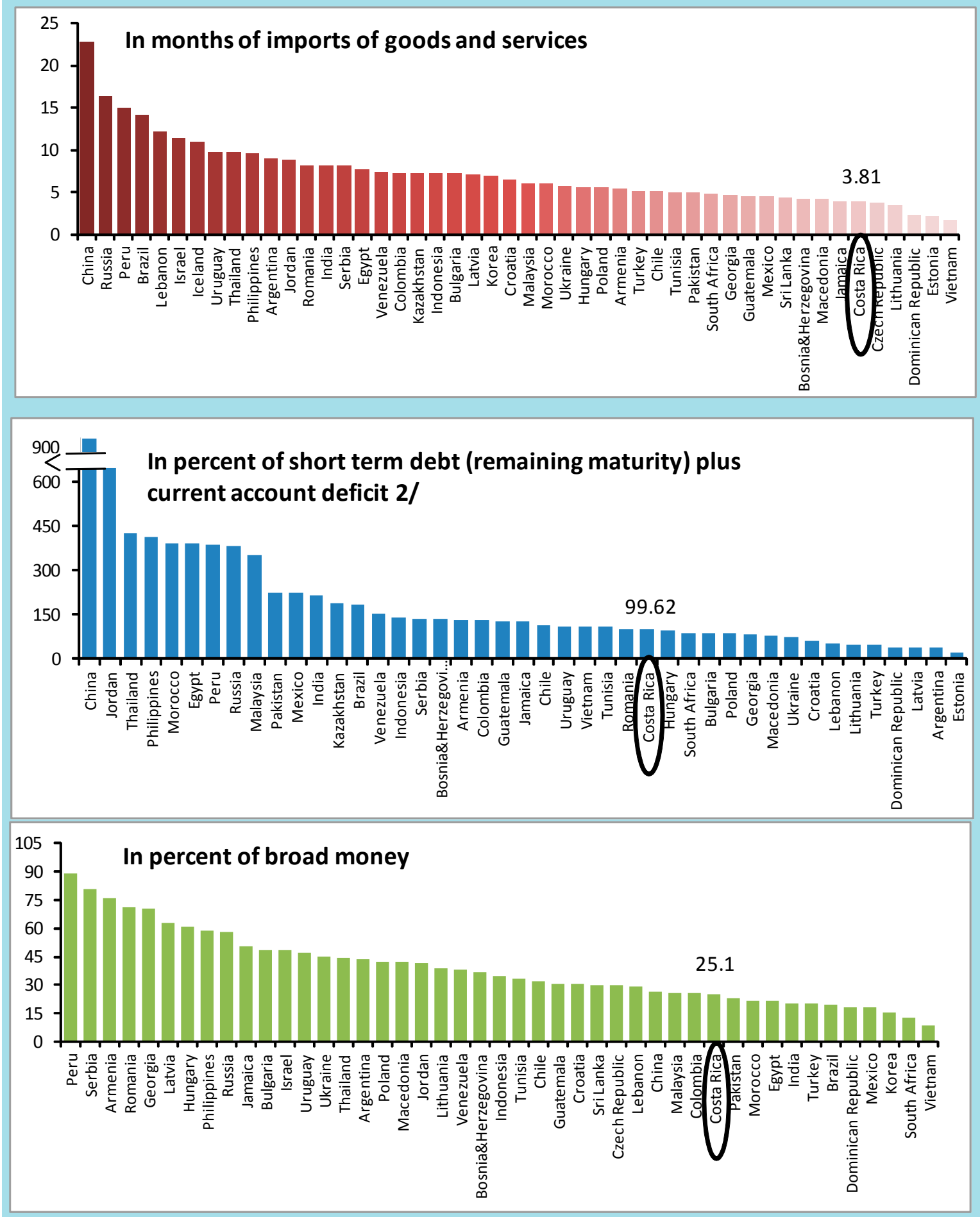

Source: Fund staff estimates.

1/ End-2010 staff estimates for gross international reserves.

2/ Gross international reserves at end 2010 in percent of external debt at remaining maturity in 2010, plus the current account deficit projected for 2011. 
Figure 4. Costa Rica: Fiscal Developments

In 2010, the fiscal deficit continued to increase...

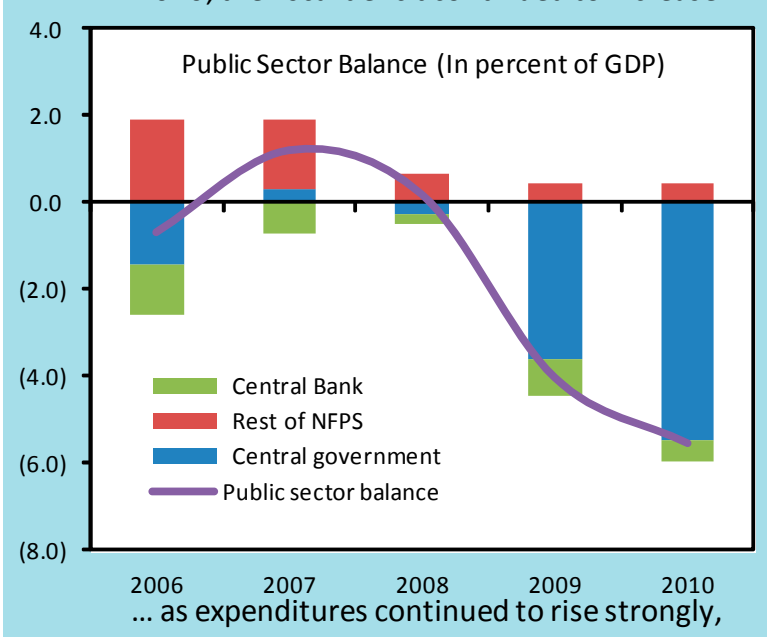
in real terms ...

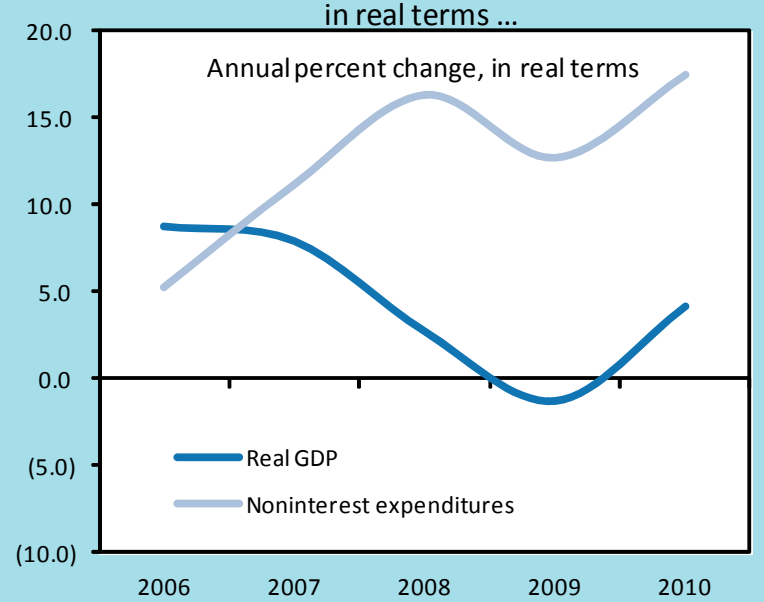

... driven by higher wages and transfers.

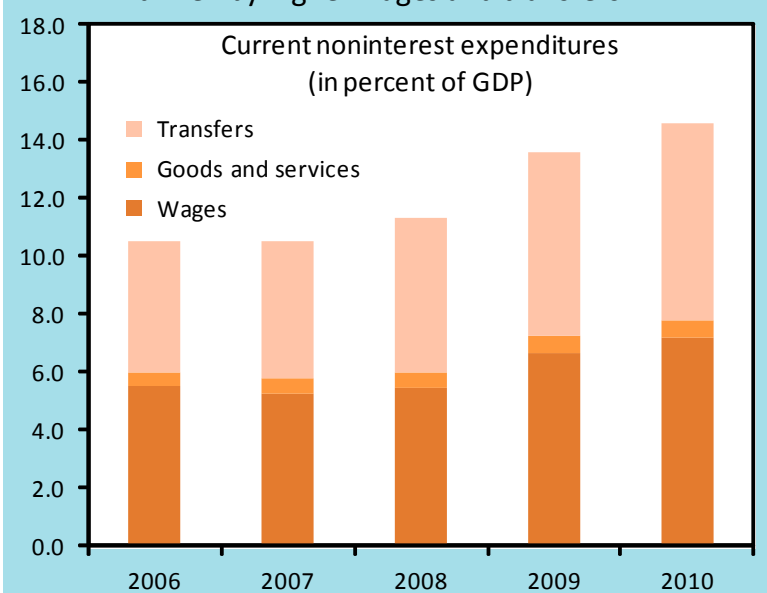

ources: Ministry of Finance and Fund staff estimates. 1 / Excluding the electricity company.
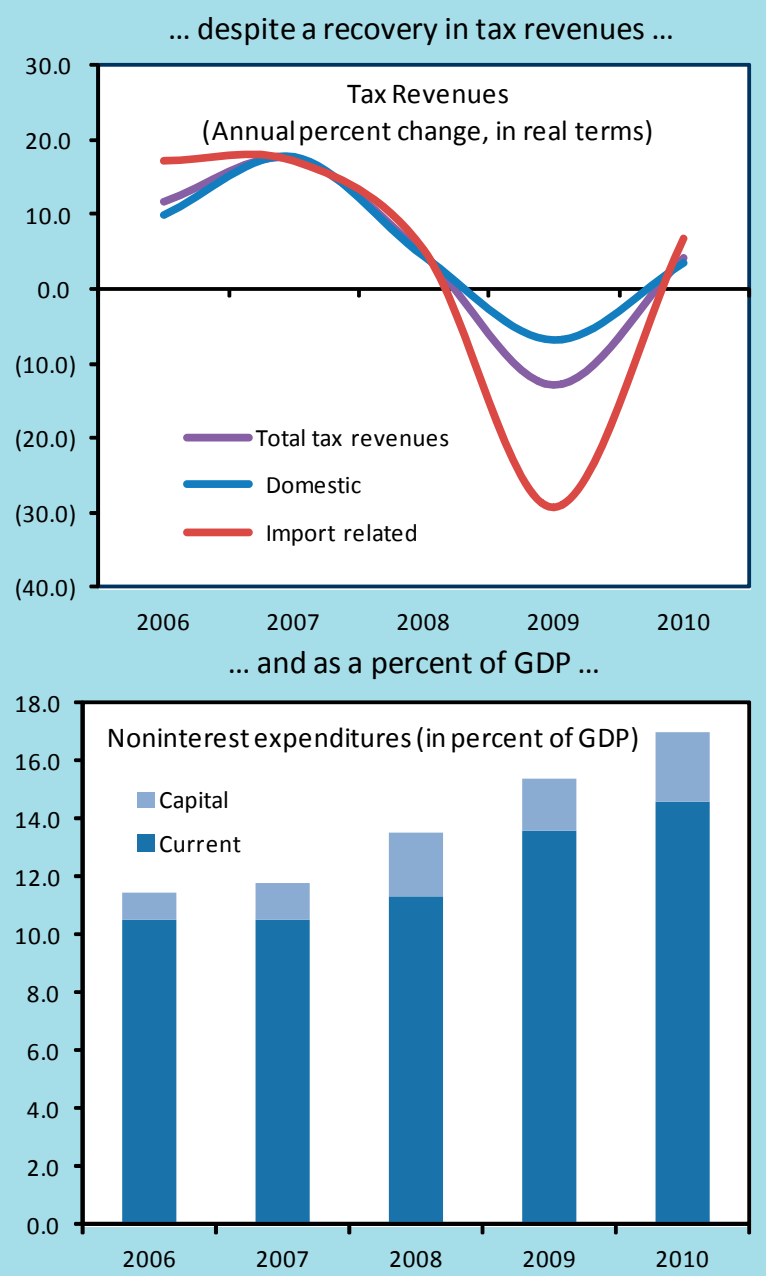

As a result, the public debt ratio increased.

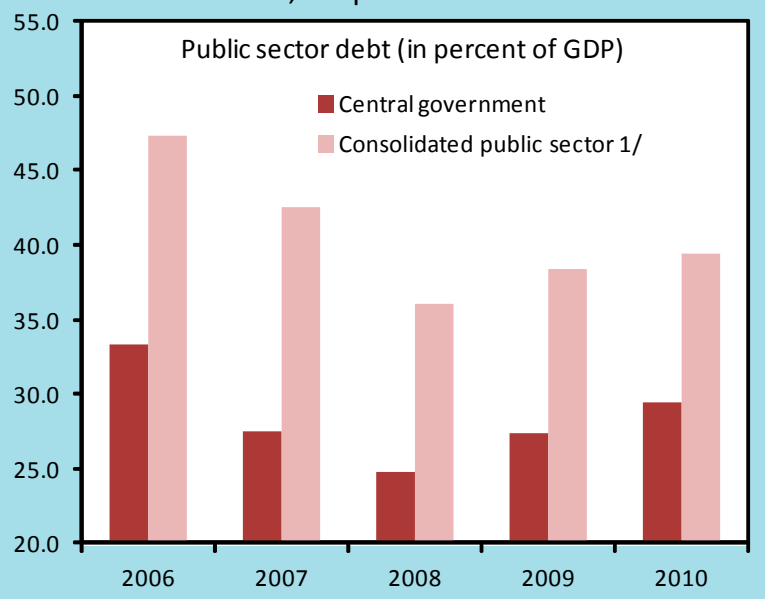




\section{Figure 5. Costa Rica: Comparative Financial Soundness Indicators}

Capitalization levels remain strong $\ldots$

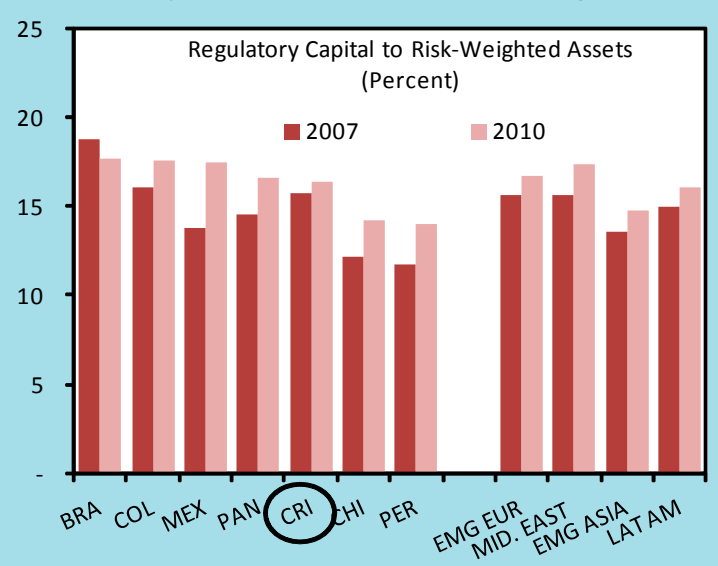

Provisions for NPLs have declined...

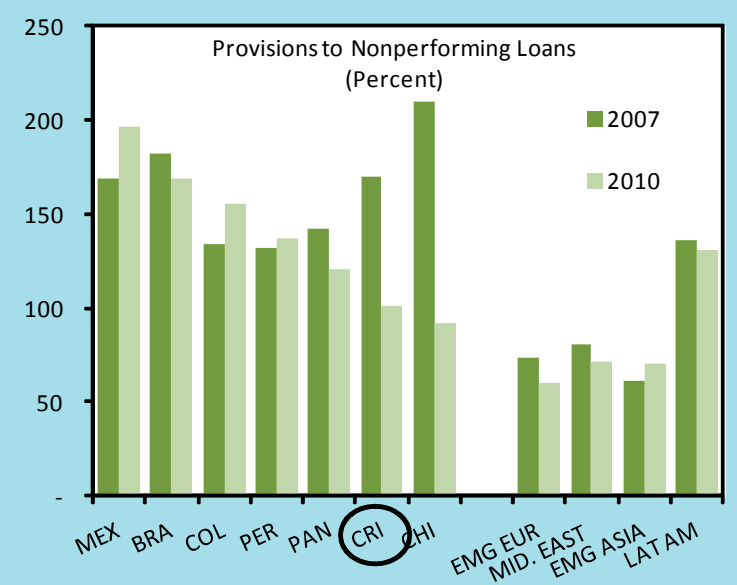

The return on assets has fallen ...

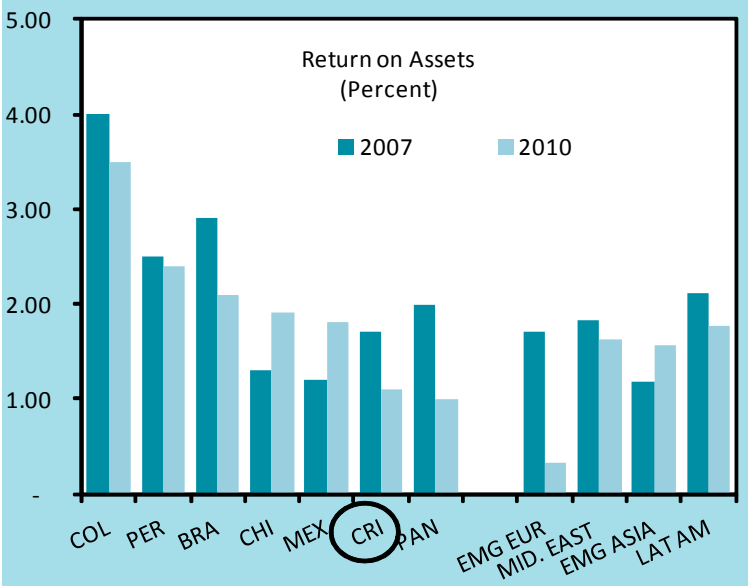

... compared to most of the region.

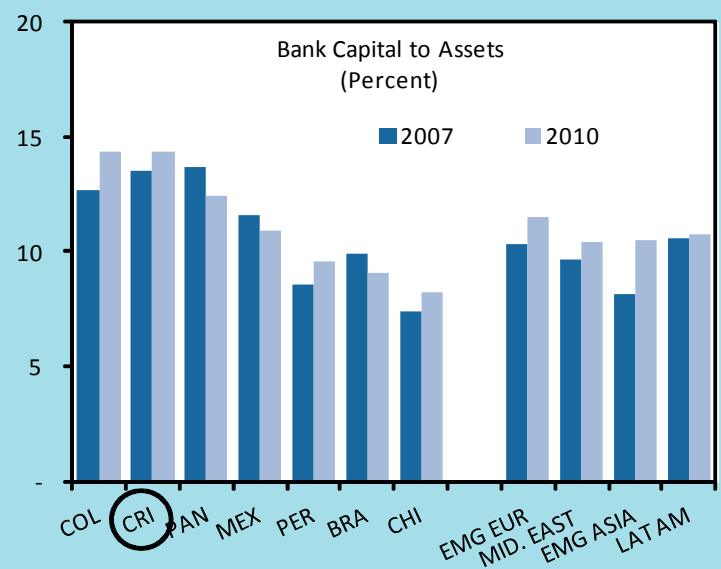

... but NPLs remain low.

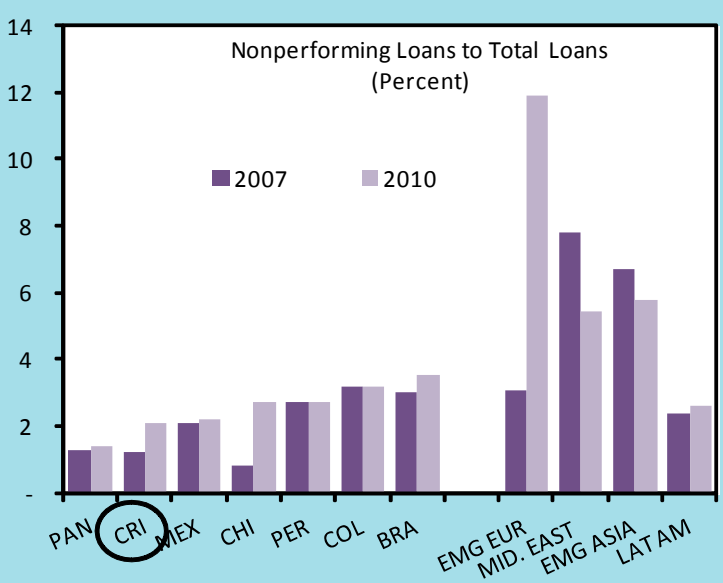

... and so has the return on equity.

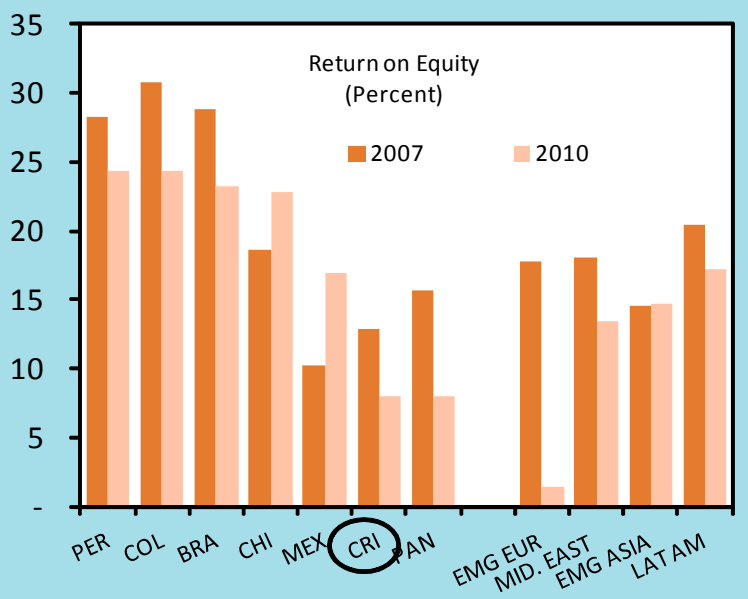

Sources: Country authorities; and Fund staff calculations. 
Figure 6. Costa Rica: Bank Deposits and Credit

While still sluggish, credit growth has resumed...

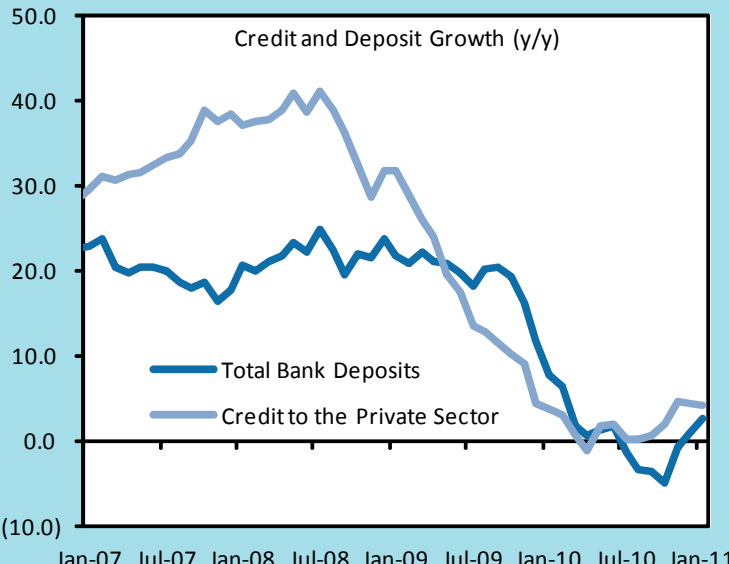

...and mostly in local currency.

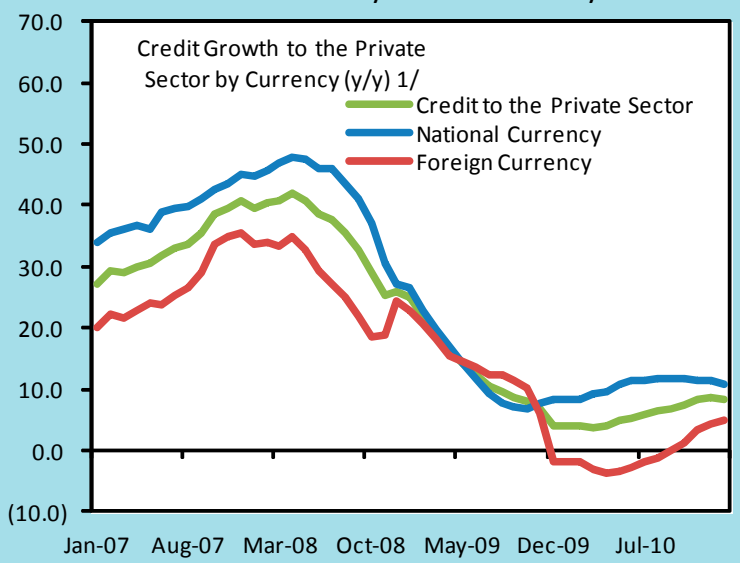

Financial dollarization declined...

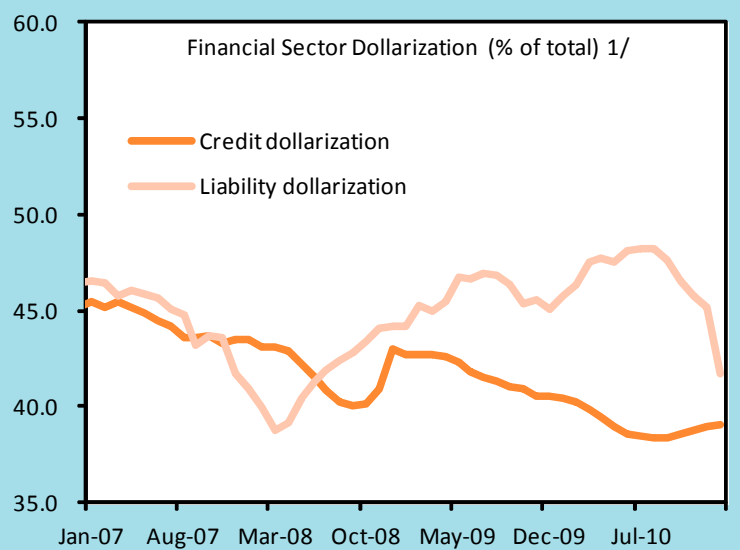

Sources: Country authorities; and Fund staff calculations. 1/ Adjusted by exchange rate.

2/ December 2007 and latest available data for 2010.

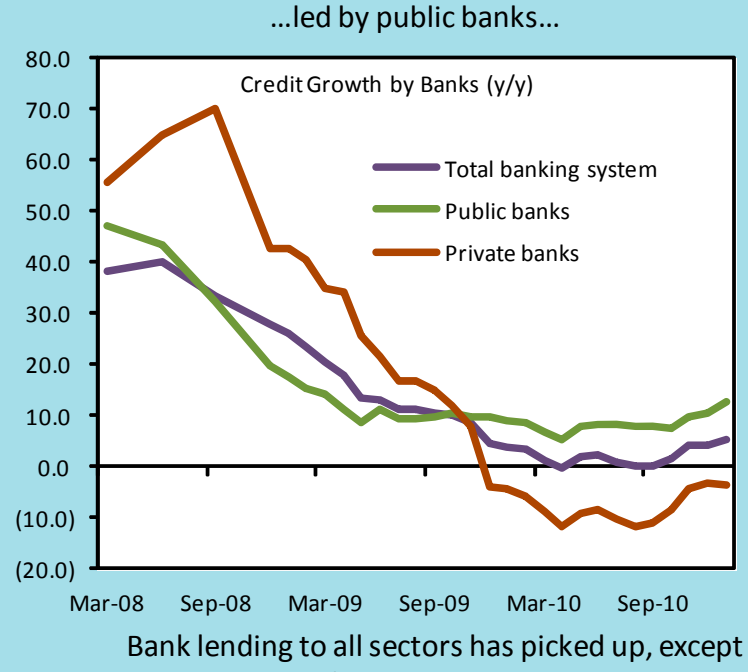
for construction.

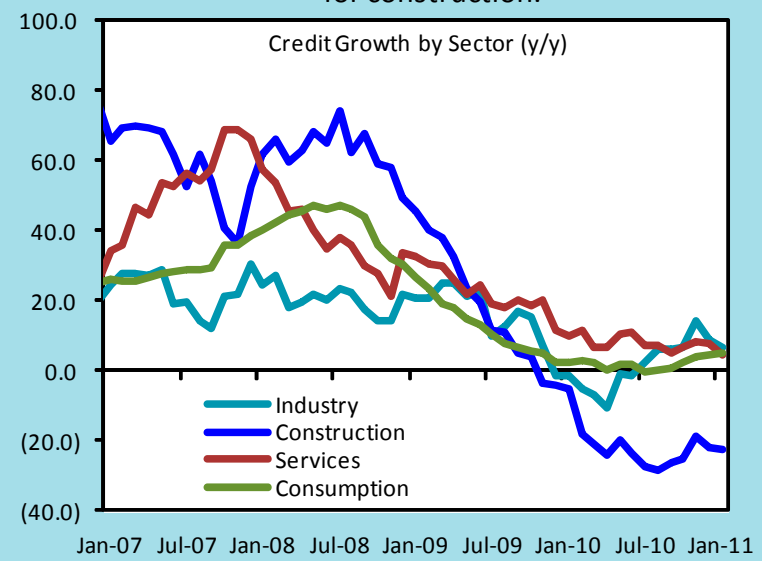

... but remains relatively high.

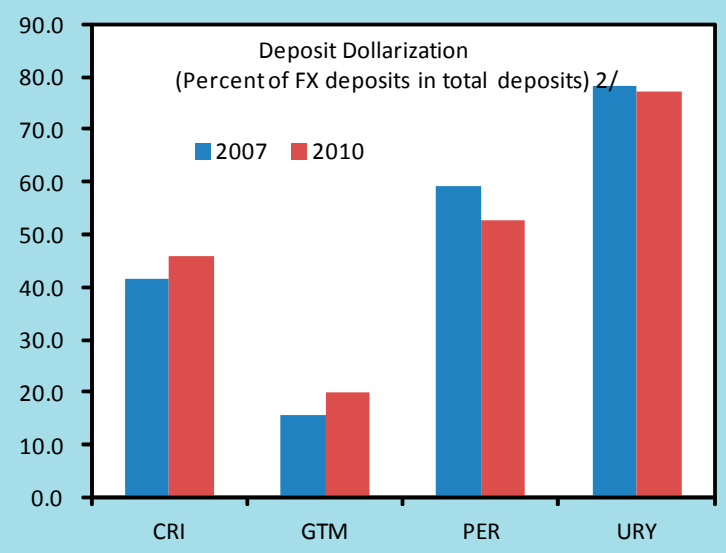


Table 1. Costa Rica: Selected Economic Indicators

Per capita GDP (2010, U.S. dollars)

Population (July 2010, millions)

Life expectancy (2009, years)
7,843

4.6

79.1
Unemployment (2010, percent of labor force)

Poverty (2009, percent of households)

Extreme poverty (2009, percent of households)
7.3

8.5

\begin{tabular}{|c|c|c|c|c|c|c|}
\hline & \multirow[b]{2}{*}{2007} & \multirow[b]{2}{*}{2008} & \multirow[b]{2}{*}{2009} & \multirow{2}{*}{$\frac{\text { Est. }}{2010}$} & \multicolumn{2}{|c|}{ Projections } \\
\hline & & & & & 2011 & 2012 \\
\hline & \multicolumn{6}{|c|}{ (Annual percentage change, unless otherwise indicated) } \\
\hline \multicolumn{7}{|l|}{ National Income and Prices } \\
\hline Real GDP growth & 7.9 & 2.7 & -1.3 & 4.2 & 4.3 & 4.4 \\
\hline GDP deflator & 9.4 & 12.4 & 8.2 & 7.8 & 5.8 & 7.2 \\
\hline Consumer prices (end of period) $1 /$ & 10.8 & 13.9 & 4.0 & 5.8 & 7.5 & 6.5 \\
\hline \multicolumn{7}{|l|}{ External Sector } \\
\hline Terms of trade (deterioration -) & -2.8 & -1.1 & 4.9 & 0.8 & -3.1 & -0.2 \\
\hline Real effective exchange rate (eop; depreciation -) & 1.5 & 3.8 & 2.1 & 12.3 & $\ldots$ & $\cdots$ \\
\hline \multicolumn{7}{|l|}{ Money and Credit } \\
\hline Monetary base & 33.0 & 11.9 & 5.1 & 11.2 & 9.7 & 11.5 \\
\hline Broad money & 17.9 & 16.1 & 9.6 & 1.3 & 12.6 & 11.4 \\
\hline Bank credit to private sector & 38.3 & 31.8 & 4.5 & 4.4 & 11.7 & 11.6 \\
\hline & \multicolumn{6}{|c|}{ (In percent of GDP) } \\
\hline \multicolumn{7}{|l|}{ Public Finances } \\
\hline Combined public sector primary balance 2/ & 5.0 & 2.8 & -0.9 & -2.7 & -2.5 & -0.5 \\
\hline Combined public sector overall balance 2/ & 1.2 & 0.2 & -4.0 & -5.6 & -5.6 & -3.9 \\
\hline Central government & 0.3 & -0.3 & -3.6 & -5.6 & -5.6 & -4.0 \\
\hline Decentralized government entities & 1.3 & 0.6 & 0.4 & 0.5 & 0.5 & 0.6 \\
\hline Public enterprises (excluding ICE) & 0.3 & 0.0 & 0.0 & 0.2 & 0.0 & 0.0 \\
\hline Central Bank & -0.7 & -0.2 & -0.8 & -0.6 & -0.5 & -0.4 \\
\hline Combined public sector debt (excluding ICE) 2/ & 42.5 & 36.0 & 38.4 & 39.4 & 42.0 & 42.8 \\
\hline Of which: External public debt & 9.7 & 8.6 & 7.2 & 7.1 & 6.8 & 7.0 \\
\hline Combined public sector debt (including ICE) 3/ & 45.3 & 39.5 & 42.5 & 42.8 & 45.4 & 46.1 \\
\hline \multicolumn{7}{|l|}{ Savings and Investment } \\
\hline Gross domestic investment & 24.7 & 27.6 & 15.9 & 20.0 & 20.2 & 20.8 \\
\hline Gross national savings & 18.4 & 18.2 & 13.9 & 16.3 & 15.4 & 15.8 \\
\hline \multicolumn{7}{|l|}{ External Sector } \\
\hline Trade balance & -11.3 & -16.8 & -7.0 & -10.0 & -11.6 & -12.2 \\
\hline Current account balance & -6.3 & -9.3 & -2.0 & -3.6 & -4.8 & -5.0 \\
\hline \multirow[t]{2}{*}{ Foreign direct investment } & 6.2 & 6.9 & 4.6 & 4.1 & 4.6 & 4.5 \\
\hline & \multicolumn{6}{|c|}{ (In millions of U.S. dollars, unless otherwise indicated) } \\
\hline Change in net international reserves (increase -) & -999 & 315 & -268 & -561 & -400 & -300 \\
\hline Net international reserves & 4,114 & 3,799 & 4,066 & 4,627 & 5,027 & 5,327 \\
\hline In months of nonmaquila imports of G\&S & 3.8 & 4.7 & 4.0 & 4.2 & 4.1 & 4.1 \\
\hline Gross domestic product & 26,322 & 29,838 & 29,241 & 35,780 & 40,167 & 43,112 \\
\hline
\end{tabular}

Sources: Central Bank of Costa Rica; Ministry of Finance; and Fund staff projections.

1/ The projection for 2011 includes a one-off impact from the tax reform (assumed to be approved later in 2011).

2/ Combined public sector $=$ central government + central bank + decentralized government entities + public enterprises, excluding the Instituto de Electricidad (ICE).

$3 /$ Includes debt by the Instituto de Electricidad (ICE) guaranteed by the government. 
Table 2. Costa Rica: Balance of Payments

(In millions of U.S. dollars, unless otherwise indicated)

\begin{tabular}{|c|c|c|c|c|c|c|c|c|c|c|}
\hline & & & & Est. & & & Projec & ection & & \\
\hline & 2007 & 2008 & 2009 & 2010 & 2011 & 2012 & 2013 & 2014 & 2015 & 2016 \\
\hline Current Account & $-1,646$ & $-2,787$ & -574 & $-1,299$ & $-1,936$ & $-2,156$ & $-2,331$ & $-2,490$ & $-2,625$ & $-2,757$ \\
\hline Trade balance & $-2,985$ & $-5,013$ & $-2,037$ & $-3,588$ & $-4,642$ & $-5,259$ & $-5,957$ & $-6,485$ & $-6,808$ & $-7,230$ \\
\hline Export of goods (f.o.b.) & 9,299 & 9,555 & 8,838 & 9,417 & 10,382 & 11,220 & 11,897 & 12,704 & 13,579 & 14,417 \\
\hline Import of goods (f.o.b.) & 12,285 & 14,569 & 10,875 & 13,004 & 15,024 & 16,479 & 17,854 & 19,189 & 20,387 & 21,647 \\
\hline Services & 1,734 & 2,201 & 2,188 & 2,661 & 3,075 & 3,448 & 3,847 & 4,244 & 4,558 & 4,923 \\
\hline Income & -865 & -417 & $-1,084$ & -740 & -751 & -851 & -817 & -913 & $-1,108$ & $-1,253$ \\
\hline Current transfers & 470 & 442 & 359 & 368 & 382 & 507 & 596 & 664 & 733 & 802 \\
\hline Financial and Capital Account & 2,273 & 2,513 & 643 & 2,097 & 2,336 & 2,456 & 2,631 & 2,765 & 2,875 & 3,007 \\
\hline Foreign direct investment & 1,634 & 2,072 & 1,339 & 1,450 & 1,841 & 1,936 & 1,994 & 2,128 & 2,199 & 2,347 \\
\hline Non-FDI flows & 618 & 433 & -754 & 597 & 495 & 520 & 637 & 637 & 676 & 661 \\
\hline Public sector & 0 & 11 & 302 & 366 & 69 & 234 & 365 & 385 & 435 & 435 \\
\hline Disbursements & 236 & 737 & 596 & 776 & 569 & 771 & 816 & 836 & 636 & 636 \\
\hline Amortization & -237 & -726 & -295 & -410 & -500 & -537 & -451 & -451 & -201 & -201 \\
\hline Private sector & 618 & 422 & $-1,056$ & 231 & 425 & 286 & 272 & 252 & 241 & 226 \\
\hline Errors and Omissions & 213 & -41 & -10 & -237 & 0 & 0 & 0 & 0 & 0 & 0 \\
\hline Change in Net Reserves (increase -) & -839 & 315 & -59 & -561 & -400 & -300 & -300 & -275 & -250 & -250 \\
\hline & & & & (Annu & al percen & atage cha & ange) & & & \\
\hline Exports of goods (f.o.b.) & & & & & & & & & & \\
\hline Value & 14.8 & 2.8 & -7.5 & 6.5 & 10.3 & 8.1 & 6.0 & 6.8 & 6.9 & 6.2 \\
\hline Volume & 9.2 & -4.4 & -4.6 & 3.6 & 5.0 & 4.7 & 5.3 & 5.7 & 5.8 & 5.5 \\
\hline Imports of goods (c.i.f.) & & & & & & & & & & \\
\hline Value & 12.7 & 18.2 & -25.4 & 19.6 & 15.6 & 9.7 & 8.3 & 7.5 & 6.2 & 6.2 \\
\hline Volume & 3.7 & 8.6 & -21.0 & 14.3 & 6.0 & 6.5 & 6.7 & 6.9 & 6.2 & 6.2 \\
\hline Of which: oil & & & & & & & & & & \\
\hline Value & 15.6 & 44.7 & -40.7 & 35.3 & 40.5 & 6.3 & 2.6 & 3.5 & 4.5 & 5.0 \\
\hline Volume & 4.6 & 2.6 & -3.7 & 6.4 & 6.0 & 5.5 & 5.0 & 4.5 & 4.0 & 4.0 \\
\hline & & & & & n percent & t of GDP) & & & & \\
\hline Current account & -6.3 & -9.3 & -2.0 & -3.6 & -4.8 & -5.0 & -5.1 & -5.2 & -5.2 & -5.2 \\
\hline Non-oil current account & -0.8 & -2.3 & 2.3 & 1.1 & 1.0 & 0.8 & 0.5 & 0.4 & 0.3 & 0.3 \\
\hline Export of goods (f.o.b.) & 35.3 & 32.0 & 30.2 & 26.3 & 25.8 & 26.0 & 26.0 & 26.4 & 26.9 & 27.3 \\
\hline Import of goods (f.o.b.) & 46.7 & 48.8 & 37.2 & 36.3 & 37.4 & 38.2 & 39.1 & 39.8 & 40.4 & 40.9 \\
\hline Non-oil goods imports (f.o.b.) & 41.2 & 41.8 & 33.0 & 31.7 & 31.5 & 32.4 & 33.4 & 34.3 & 34.9 & 35.4 \\
\hline Income & -3.3 & -1.4 & -3.7 & -2.1 & -1.9 & -2.0 & -1.8 & -1.9 & -2.2 & -2.4 \\
\hline Direct investment & 6.2 & 6.9 & 4.6 & 4.1 & 4.6 & 4.5 & 4.4 & 4.4 & 4.4 & 4.4 \\
\hline Memorandum Items: & & & & & & & & & & \\
\hline Net international reserves (US\$ million) 1/ & 4,114 & 3,799 & 4,066 & 4,627 & 5,027 & 5,327 & 5,627 & 5,902 & 6,152 & 6,402 \\
\hline In months of non-maquila imports & 3.8 & 4.7 & 4.0 & 4.2 & 4.1 & 4.1 & 4.1 & 4.0 & 4.0 & 4.0 \\
\hline In percent short-term debt $2 /$ & 96.7 & 88.4 & 133.7 & 138.3 & 133.4 & 129.4 & 122.0 & 139.5 & 126.5 & 129.0 \\
\hline
\end{tabular}

Sources: Central Bank of Costa Rica; and Fund staff estimates.

$1 /$ Includes valuation adjustments of US $\$ 160$ million in 2007 for reclassification of capital contribution to FLAR and US\$209 million in $\mathbf{2 0 0 9}$ for the SDR allocation.

2/ Public and private sector external debt on remaining maturity. Includes trade credit. 
Table 3. Costa Rica: Central Government Balance

(In billions of colones)

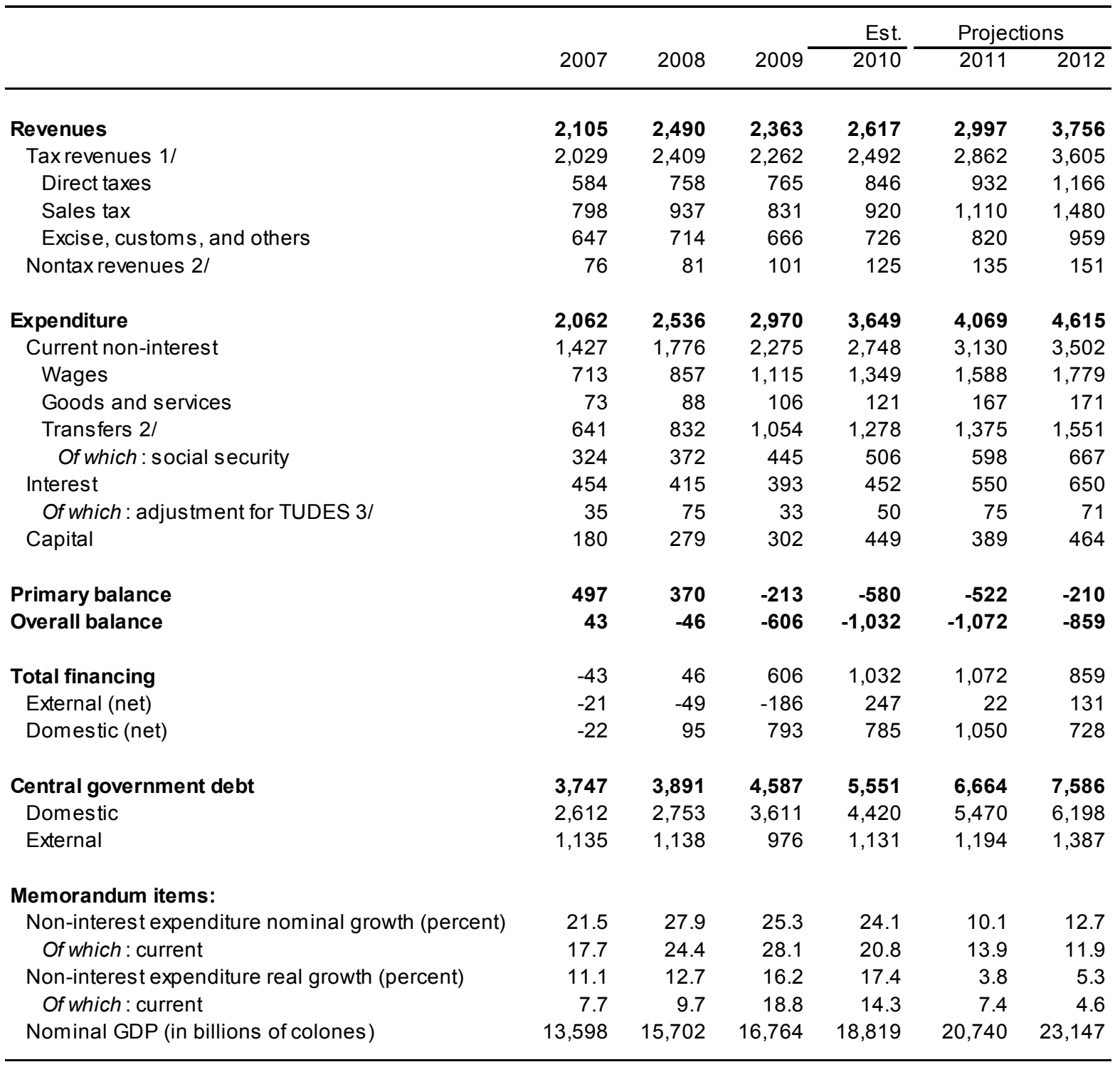

Sources: Ministry of Finance and IMF staff.

1/ Assumes that the tax reform submitted to the National Assembly becomes effective in the second-half of 2011.

2/ Transfers to the Social Development and Family Transfers Fund (FODESAF) are accounted for in net terms.

$3 /$ TUDES is an inflation-indexed bond whose value is adjusted monthly in line with inflation and that pays a fixed rate coupon twice a year, calculated over the adjusted value of the bond. The inflation adjustment of the principal is not reflected as interest expenditure in the official fiscal accounts, but is added in the Fund presentation of the fiscal balance. 
Table 4. Costa Rica: Central Government Balance

(In percent of GDP)

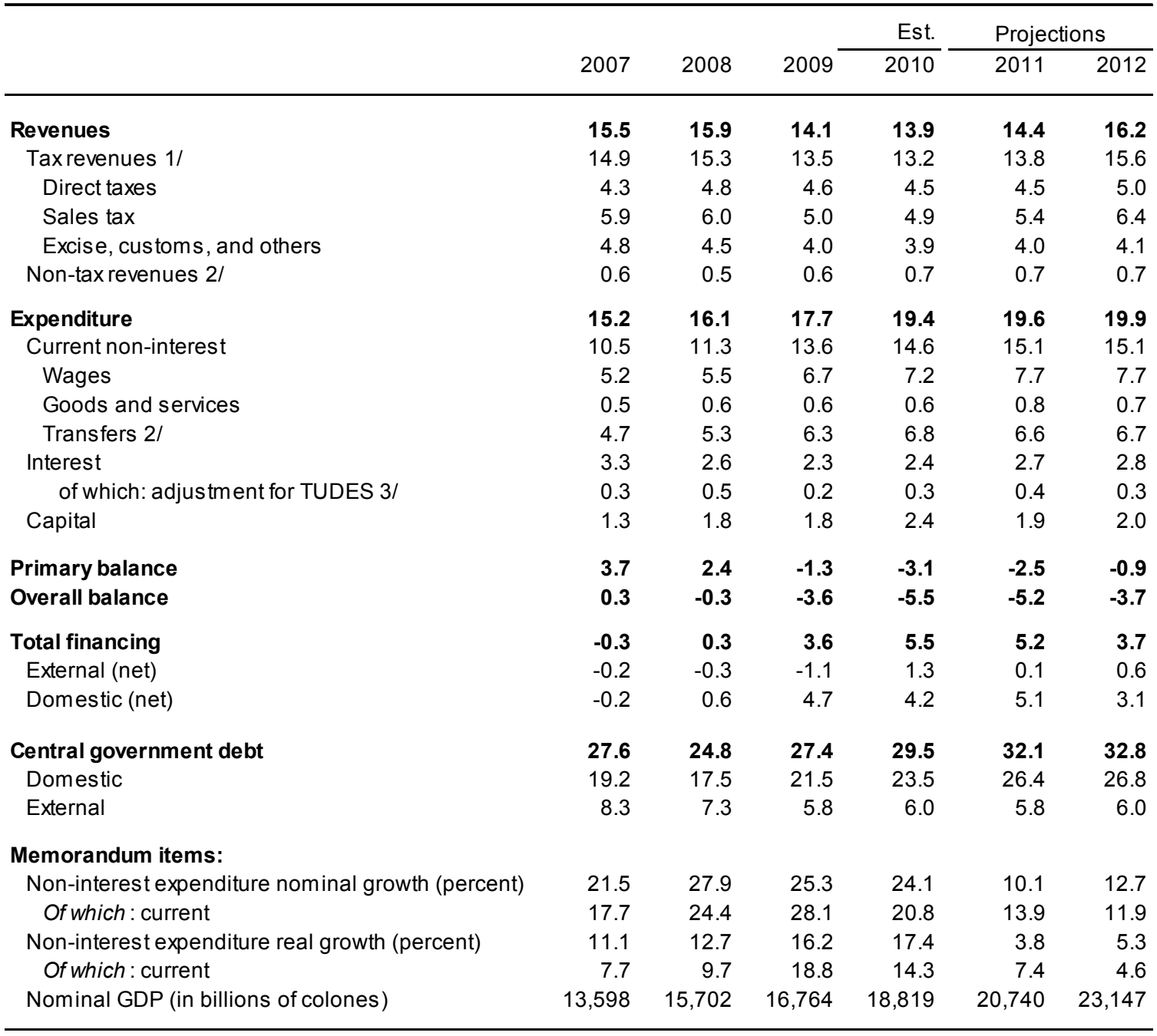

Sources: Ministry of Finance and IMF staff.

1/ Assumes that the tax reform submitted to the National Assembly becomes effective in the second-half of 2011. 2/ Transfers to the Social Development and Family Transfers Fund (FODESAF) are accounted for in net terms.

3/ TUDES is an inflation-indexed bond whose value is adjusted monthly in line with inflation and that pays a fixed rate coupon twice a year, calculated over the adjusted value of the bond. The inflation adjustment of the principal is not reflected as interest expenditure in the official fiscal accounts, but is added in the Fund presentation of the fiscal balance. 
Table 5. Costa Rica: Combined Public Sector Operations 1/

(In billions of colones)

\begin{tabular}{|c|c|c|c|c|c|c|}
\hline & & & & Est. & Projec & ons \\
\hline & 2007 & 2008 & 2009 & 2010 & 2011 & 2012 \\
\hline Non-financial public sector: & & & & & & \\
\hline Revenues & 3,187 & 3,700 & 3,768 & 4,179 & 4,672 & 5,625 \\
\hline Tax revenues 2/ & 2,055 & 2,437 & 2,289 & 2,520 & 2,893 & 3,640 \\
\hline Nontax revenues & 172 & 161 & 218 & 245 & 270 & 301 \\
\hline Social security contributions & 871 & 1,057 & 1,186 & 1,332 & 1,468 & 1,638 \\
\hline Operating balance of public enterprises & 89 & 46 & 75 & 83 & 41 & 46 \\
\hline Expenditure & 2,926 & 3,640 & 4,302 & 5,130 & 5,739 & 6,476 \\
\hline Current non-interest & 2,221 & 2,755 & 3,428 & 4,047 & 4,582 & 5,127 \\
\hline Wages & 977 & 1,201 & 1,545 & 1,839 & 2,148 & 2,404 \\
\hline Goods and services & 288 & 355 & 387 & 441 & 520 & 569 \\
\hline Transfers & 956 & 1,199 & 1,497 & 1,767 & 1,914 & 2,153 \\
\hline Interest & 418 & 383 & 381 & 446 & 561 & 662 \\
\hline Of which: adjustment for TUDES $3 /$ & -3 & 41 & 18 & 28 & 41 & 39 \\
\hline Capital & 286 & 503 & 493 & 637 & 596 & 687 \\
\hline Of which : central government & 180 & 279 & 302 & 449 & 389 & 464 \\
\hline Of which: rest of non-financial public sector & 106 & 224 & 192 & 188 & 207 & 224 \\
\hline Nonfinancial public sector primary balance & 679 & 443 & -154 & -504 & -506 & -189 \\
\hline Nonfinancial public sector overall balance & 261 & 60 & -535 & -951 & $-1,067$ & -851 \\
\hline Central government & 43 & -46 & -606 & $-1,032$ & $-1,072$ & -859 \\
\hline Decentralized government entities & 172 & 101 & 73 & 50 & 5 & 8 \\
\hline Public enterprises (excluding ICE) & 46 & 4 & -2 & 31 & 0 & 0 \\
\hline Total financing & -261 & -60 & 535 & 951 & 1,067 & 851 \\
\hline External & -17 & -54 & -188 & 247 & 5 & 108 \\
\hline Domestic & -244 & -6 & 723 & 704 & 1,063 & 743 \\
\hline Central Bank balance & -96 & -29 & -138 & -88 & -104 & -116 \\
\hline Combined public sector balance (includes Central Bank) & 165 & 31 & -673 & $-1,039$ & $-1,171$ & -967 \\
\hline Public sector debt (excluding ICE) & 5,777 & 5,659 & 6,443 & 7,411 & 8,673 & 9,790 \\
\hline Domestic & 4,457 & 4,306 & 5,236 & 6,076 & 7,290 & 8,233 \\
\hline External & 1,320 & 1,353 & 1,207 & 1,335 & 1,383 & 1,557 \\
\hline Memorandum items: & & & & & & \\
\hline Public sector debt (including ICE) & 6,158 & 6,199 & 7,127 & 8,051 & 9,388 & 10,573 \\
\hline Non-interest expenditure nominal growth (percent) & 21.4 & 29.9 & 20.4 & 19.4 & 10.6 & 12.3 \\
\hline Of which: current & 19.9 & 24.0 & 24.4 & 18.0 & 13.2 & 11.9 \\
\hline Non-interest expenditure real growth (percent) & 11.0 & 14.6 & 11.6 & 13.0 & 4.3 & 4.9 \\
\hline Of which: current & 9.7 & 9.3 & 15.4 & 11.7 & 6.8 & 4.6 \\
\hline Nominal GDP (in billions of colones) & 13,598 & 15,702 & 16,764 & 18,819 & 20,740 & 23,147 \\
\hline CPI Inflation (period average) & 9.4 & 13.4 & 7.8 & 5.7 & 6.0 & 7.0 \\
\hline
\end{tabular}

Sources: Ministry of Finance and IMF staff estimates.

$1 /$ Combined public sector $=$ central government + central bank + decentralized government entities + public enterprises, excluding the Instituto de Electricidad (ICE).

2/ Assumes that the tax reform submitted to the National Assembly becomes effective in the second half of 2011.

$3 /$ TUDES is an inflation-indexed bond whose value is adjusted monthly in line with inflation and that pays a fixed rate coupon twice a year, calculated over the adjusted value of the bond. The inflation adjustment of the principal is not reflected as interest expenditure in the official fiscal accounts, but is added in the Fund presentation of the fiscal balance. 
Table 6. Costa Rica: Combined Public Sector Operations 1/ (In percent of GDP)

\begin{tabular}{|c|c|c|c|c|c|c|}
\hline & \multirow[b]{2}{*}{2007} & \multirow[b]{2}{*}{2008} & \multirow[b]{2}{*}{2009} & \multirow{2}{*}{$\frac{\text { Est. }}{2010}$} & \multicolumn{2}{|c|}{ Projections } \\
\hline & & & & & 2011 & 2012 \\
\hline Revenues & 23.4 & 23.6 & 22.5 & 22.2 & 22.5 & 24.3 \\
\hline Tax revenues 2/ & 15.1 & 15.5 & 13.7 & 13.4 & 13.9 & 15.7 \\
\hline Non-tax revenues & 1.3 & 1.0 & 1.3 & 1.3 & 1.3 & 1.3 \\
\hline Social security contributions & 6.4 & 6.7 & 7.1 & 7.1 & 7.1 & 7.1 \\
\hline Operating balance of public enterprises & 0.7 & 0.3 & 0.4 & 0.4 & 0.2 & 0.2 \\
\hline Expenditure & 21.5 & 23.2 & 25.7 & 27.3 & 27.7 & 28.0 \\
\hline Current non-interest & 16.3 & 17.5 & 20.5 & 21.5 & 22.1 & 22.1 \\
\hline Wages & 7.2 & 7.6 & 9.2 & 9.8 & 10.4 & 10.4 \\
\hline Goods and services & 2.1 & 2.3 & 2.3 & 2.3 & 2.5 & 2.5 \\
\hline Transfers & 7.0 & 7.6 & 8.9 & 9.4 & 9.2 & 9.3 \\
\hline Interest & 3.1 & 2.4 & 2.3 & 2.4 & 2.7 & 2.9 \\
\hline of which: adjus tment for TUDES 3/ & 0.0 & 0.3 & 0.1 & 0.1 & 0.2 & 0.2 \\
\hline Capital & 2.1 & 3.2 & 2.9 & 3.4 & 2.9 & 3.0 \\
\hline of which: central government & 1.3 & 1.8 & 1.8 & 2.4 & 1.9 & 2.0 \\
\hline of which: rest of non-financial public sector & 0.8 & 1.4 & 1.1 & 1.0 & 1.0 & 1.0 \\
\hline Nonfinancial public sector primary balance & 5.0 & 2.8 & -0.9 & -2.7 & -2.4 & -0.8 \\
\hline Nonfinancial public sector overall balance & 1.9 & 0.4 & -3.2 & -5.1 & -5.1 & -3.7 \\
\hline Central government & 0.3 & -0.3 & -3.6 & -5.5 & -5.2 & -3.7 \\
\hline Decentralized government entities & 1.3 & 0.6 & 0.4 & 0.3 & 0.0 & 0.0 \\
\hline Public enterprises (excluding ICE) & 0.3 & 0.0 & 0.0 & 0.2 & 0.0 & 0.0 \\
\hline Total financing & -1.9 & -0.4 & 3.2 & 5.1 & 5.1 & 3.7 \\
\hline External & -0.1 & -0.3 & -1.1 & 1.3 & 0.0 & 0.5 \\
\hline Domestic & -1.8 & 0.0 & 4.3 & 3.7 & 5.1 & 3.2 \\
\hline Central Bank balance & -0.7 & -0.2 & -0.8 & -0.5 & -0.5 & -0.5 \\
\hline Combined public sector balance (includes Central Bank) & 1.2 & 0.2 & -4.0 & -5.5 & -5.6 & -4.2 \\
\hline Public sector debt (excluding ICE) & 42.5 & 36.0 & 38.4 & 39.4 & 41.8 & 42.3 \\
\hline Domestic & 32.8 & 27.4 & 31.2 & 32.3 & 35.1 & 35.6 \\
\hline External & 9.7 & 8.6 & 7.2 & 7.1 & 6.7 & 6.7 \\
\hline \multicolumn{7}{|l|}{ Memorandum items: } \\
\hline Public sector debt (including ICE) & 45.3 & 39.5 & 42.5 & 42.8 & 45.3 & 45.7 \\
\hline Non-interest expenditure nominal growth (percent) & 21.4 & 29.9 & 20.4 & 19.4 & 10.6 & 12.3 \\
\hline of which: current & 19.9 & 24.0 & 24.4 & 18.0 & 13.2 & 11.9 \\
\hline Non-interest expenditure real growth (percent) & 11.0 & 14.6 & 11.6 & 13.0 & 4.3 & 4.9 \\
\hline of which: current & 9.7 & 9.3 & 15.4 & 11.7 & 6.8 & 4.6 \\
\hline Nominal GDP (in billions of colones) & 13,598 & 15,702 & 16,764 & 18,819 & 20,740 & 23,147 \\
\hline
\end{tabular}

Sources: Ministry of Finance and IMF staff estimates.

1/ Combined public sector $=$ central government + central bank + decentralized government entities + public enterprises , excluding the Instituto de Electricidad (ICE).

2/ Assumes that the tax reform submitted to the National Assembly becomes effective in the second half of 2011. $3 /$ TUDES is an inflation-indexed bond whose value is adjusted monthly in line with inflation and that pays a fixed rate coupon twice a year, calculated over the adjusted value of the bond. The inflation adjustment of the principal is not reflected as interest expenditure in the official fiscal accounts, but is added in the Fund presentation of the fiscal balance. 
Table 7. Costa Rica: Monetary Survey

(In billions of colones, unless otherwise indicated)

\begin{tabular}{|c|c|c|c|c|c|}
\hline & 2007 & 2008 & $2009^{-}$ & $\frac{\text { Est. }}{2010}$ & $\frac{\text { Proj. }}{2011}$ \\
\hline \multicolumn{6}{|l|}{ Central Bank } \\
\hline Net foreign assets & 2,125 & 2,186 & 2,420 & 2,492 & 2,764 \\
\hline Net international reserves & 2,037 & 2,090 & 2,272 & 2,350 & 2,608 \\
\hline (In millions of US\$) & 4,114 & 3,799 & 4,066 & 4,627 & 5,027 \\
\hline Net Medium-Term Foreign Assets & 107 & 116 & 140 & 140 & 140 \\
\hline Net domestic assets & $-1,097$ & $-1,035$ & $-1,210$ & $-1,147$ & $-1,288$ \\
\hline Net domestic credit & -429 & -547 & -792 & -926 & $-1,000$ \\
\hline Capital account (-) & 1,182 & 1,219 & 1,266 & 1,346 & 1,471 \\
\hline Other items net (-) & -5 & -193 & -270 & -159 & -122 \\
\hline Monetary stabilization bonds (-) & $-1,845$ & $-1,513$ & $-1,414$ & $-1,407$ & $-1,637$ \\
\hline Monetary base & 1,028 & 1,151 & 1,210 & 1,345 & 1,476 \\
\hline Currency & 546 & 575 & 613 & 665 & 724 \\
\hline Required reserves & 482 & 576 & 597 & 680 & 752 \\
\hline \multicolumn{6}{|l|}{ Other Depository Institutions } \\
\hline Net foreign assets & -313 & -420 & -20 & -87 & -250 \\
\hline Net domestic assets & 6,175 & 7,674 & 8,128 & 8,183 & 9,368 \\
\hline Net domestic credit & 8,097 & 10,064 & 11,087 & 11,776 & 13,694 \\
\hline Credit to nonfinancial public sector (net) & 338 & 316 & 586 & 872 & 1,572 \\
\hline Credit to the private sector & 6,013 & 7,925 & 8,281 & 8,645 & 9,657 \\
\hline Credit to financial corporations (net) & 1,745 & 1,823 & 2,221 & 2,260 & 2,465 \\
\hline Capital account & 1,237 & 1,597 & 1,829 & 2,036 & 2,362 \\
\hline Other items (net) & -685 & -793 & $-1,129$ & $-1,557$ & $-1,964$ \\
\hline Liabilities & 5,862 & 7,254 & 8,108 & 8,096 & 9,118 \\
\hline National currency & 3,481 & 3,940 & 4,299 & 4,731 & 5,092 \\
\hline Foreign currency & 2,381 & 3,314 & 3,809 & 3,364 & 4,026 \\
\hline \multicolumn{6}{|l|}{ Financial System } \\
\hline Net foreign assets & 1,812 & 1,766 & 2,400 & 2,405 & 2,514 \\
\hline Net domestic assets & 5,640 & 6,885 & 7,078 & 7,194 & 8,294 \\
\hline Net domestic credit & 6,291 & 8,221 & 8,816 & 9,228 & 11,001 \\
\hline Capital account & 55 & 378 & 564 & 690 & 891 \\
\hline Other items (net) & -595 & -957 & $-1,174$ & $-1,344$ & $-1,816$ \\
\hline Broad money (M4) & 7,453 & 8,651 & 9,478 & 9,599 & 10,808 \\
\hline \multicolumn{6}{|l|}{ Memorandum Items: } \\
\hline & \multicolumn{5}{|c|}{ (Percent changes) } \\
\hline Monetary base & 33.0 & 11.9 & 5.1 & 11.2 & 9.7 \\
\hline Broad money (M4) & 17.9 & 16.1 & 9.6 & 1.3 & 12.6 \\
\hline Credit to the private sector (National Currency) & 45.2 & 27.1 & 8.3 & 11.4 & 13.8 \\
\hline \multirow[t]{2}{*}{ Credit to the private sector (Foreign Currency) 1/ } & 30.0 & 38.2 & -0.3 & -5.2 & 8.3 \\
\hline & \multicolumn{5}{|c|}{ (In percent of GDP) } \\
\hline Monetary base & 7.6 & 7.3 & 7.2 & 7.1 & 7.1 \\
\hline Broad money (M4) & 54.8 & 55.1 & 56.5 & 51.0 & 52.0 \\
\hline Credit to the private sector (National Currency) & 25.5 & 28.0 & 28.4 & 28.2 & 29.1 \\
\hline Credit to the private sector (Foreign Currency) & 18.8 & 22.4 & 21.0 & 17.7 & 17.4 \\
\hline
\end{tabular}

Sources: Central Bank; and Fund staff estimates.

1 / Measured in U.S. dollar terms. 
Table 8. Costa Rica: Indicators of External Vulnerability

\begin{tabular}{lrrrrrr}
\hline & & & & & \multicolumn{2}{c}{ Projection } \\
\cline { 5 - 7 } & 2007 & 2008 & 2009 & 2010 & 2011 & 2012 \\
\hline & & & & & & \\
Merchandise exports (percent change) & 14.8 & 2.8 & -7.5 & 6.5 & 10.3 & 8.1 \\
Merchandise imports (percent change) & 12.7 & 18.2 & -25.4 & 19.6 & 15.6 & 9.7 \\
Terms of trade (percent change) & -2.8 & -1.1 & 4.9 & 0.8 & -3.1 & -0.2 \\
Current account balance (in percent of GDP) & -6.3 & -9.3 & -2.0 & -3.6 & -4.8 & -5.0 \\
Central bank net international reserves (in US\$ millions) & 4,114 & 3,799 & 4,066 & 4,627 & 5,027 & 5,327 \\
In months of next year's imports of nonmaquila goods and services & 3.8 & 4.7 & 4.0 & 4.2 & 4.1 & 4.1 \\
In months of next year's imports of nonmaquila goods and services & 199.3 & 183.3 & 189.9 & 174.7 & 179.2 & 181.2 \\
In percent of M4 & 27.5 & 24.4 & 24.2 & 24.5 & 24.5 & 24.4 \\
In percent of deposits in foreign currency & 86.1 & 63.7 & 60.3 & 69.8 & 65.7 & 66.7 \\
In percent of short-term external debt 1/ & 96.7 & 88.4 & 133.7 & 138.3 & 133.4 & 129.4 \\
Public external debt service (in percent of GDP) & 1.6 & 3.0 & 1.6 & 1.7 & 1.7 & 1.4 \\
External debt (in percent of GDP) & 32.1 & 30.5 & 28.0 & 25.2 & 24.0 & 24.2 \\
External debt (in percent of exports) & 65.7 & 66.8 & 65.8 & 67.3 & 63.7 & 63.2 \\
REER appreciation (+) & 1.5 & 3.8 & 2.1 & 12.3 & $\ldots$ & $\ldots$ \\
\hline
\end{tabular}

Sources: Central Bank of Costa Rica; and Fund staff estimates.

1/ Public and private sector external debt on remaining maturity. Includes trade credit. 
Table 9. Costa Rica: Medium-Term Framework

(Annual percentage change; unless otherwise indicated)

\begin{tabular}{|c|c|c|c|c|c|c|c|c|c|c|}
\hline & \multirow[b]{2}{*}{2007} & \multirow[b]{2}{*}{2008} & \multirow[b]{2}{*}{2009} & \multirow[b]{2}{*}{2010} & \multicolumn{6}{|c|}{ Projection } \\
\hline & & & & & 2011 & 2012 & 2013 & 2014 & 2015 & 2016 \\
\hline Real GDP & 7.9 & 2.7 & -1.3 & 4.2 & 4.3 & 4.4 & 4.5 & 4.5 & 4.5 & 4.5 \\
\hline Consumption & 6.9 & 3.3 & 2.1 & 3.7 & 3.8 & 3.8 & 3.9 & 3.8 & 3.8 & 3.8 \\
\hline Private consumption & 7.5 & 3.2 & 1.5 & 3.4 & 3.7 & 3.7 & 3.8 & 3.8 & 3.8 & 3.8 \\
\hline Government consumption & 2.3 & 4.4 & 6.7 & 5.9 & 4.6 & 4.9 & 4.6 & 3.4 & 4.0 & 4.0 \\
\hline Gross domestic investment & -1.2 & 22.2 & -36.7 & 29.1 & 5.9 & 7.7 & 7.8 & 7.4 & 6.3 & 6.9 \\
\hline Fixed capital formation & 18.1 & 11.0 & -9.8 & 2.6 & 4.6 & 7.1 & 8.0 & 7.4 & 6.6 & 7.1 \\
\hline Exports of goods and nonfactor services & 9.9 & -2.6 & -6.0 & 4.8 & 5.1 & 5.6 & 5.7 & 6.1 & 5.9 & 5.5 \\
\hline Imports of goods and nonfactor services & 4.3 & 6.5 & -19.9 & 14.2 & 5.2 & 6.4 & 6.5 & 6.6 & 5.9 & 5.8 \\
\hline Consumption (contribution to growth) & 4.9 & 2.4 & 1.5 & 2.7 & 2.8 & 2.8 & 2.8 & 2.7 & 2.7 & 2.7 \\
\hline Investment (contribution to growth) & 3.7 & 2.5 & -2.4 & 0.6 & 1.0 & 1.6 & 1.8 & 1.7 & 1.6 & 1.7 \\
\hline Inventories (contribution to growth) & -4.0 & 2.8 & -8.1 & 4.7 & 0.4 & 0.2 & 0.1 & 0.1 & 0.0 & 0.0 \\
\hline Net exports (contribution to growth) & 3.3 & -5.0 & 7.7 & -3.8 & 0.1 & -0.2 & -0.2 & -0.1 & 0.1 & 0.0 \\
\hline \multicolumn{11}{|l|}{ Investment and savings (in percent of GDP) } \\
\hline Savings & 24.7 & 27.6 & 15.9 & 20.0 & 20.2 & 20.8 & 21.5 & 22.0 & 22.4 & 22.9 \\
\hline National savings & 18.4 & 18.2 & 13.9 & 16.3 & 15.4 & 15.8 & 16.4 & 16.9 & 17.2 & 17.7 \\
\hline External savings $1 /$ & 6.3 & 9.3 & 2.0 & 3.6 & 4.8 & 5.0 & 5.1 & 5.2 & 5.2 & 5.2 \\
\hline Gross domestic investment & 24.7 & 27.6 & 15.9 & 20.0 & 20.2 & 20.8 & 21.5 & 22.0 & 22.4 & 22.9 \\
\hline Private sector & 18.6 & 19.6 & 18.5 & 15.5 & 16.3 & 16.7 & 17.4 & 17.8 & 18.2 & 18.6 \\
\hline Public sector & 3.2 & 4.0 & 3.6 & 4.2 & 3.6 & 3.7 & 3.7 & 3.8 & 3.8 & 3.9 \\
\hline Inventory changes & 2.9 & 4.0 & -6.3 & 0.2 & 0.3 & 0.4 & 0.4 & 0.4 & 0.4 & 0.4 \\
\hline \multicolumn{11}{|l|}{ Balance of payments (in percent of GDP) } \\
\hline Current account balance & -6.3 & -9.3 & -2.0 & -3.6 & -4.8 & -5.0 & -5.1 & -5.2 & -5.2 & -5.2 \\
\hline Trade balance & -11.3 & -16.8 & -7.0 & -10.0 & -11.6 & -12.2 & -13.0 & -13.5 & -13.5 & -13.7 \\
\hline Services & 6.6 & 7.4 & 7.5 & 7.4 & 7.7 & 8.0 & 8.4 & 8.8 & 9.0 & 9.3 \\
\hline Income & -3.3 & -1.4 & -3.7 & -2.1 & -1.9 & -2.0 & -1.8 & -1.9 & -2.2 & -2.4 \\
\hline Current transfers & 1.8 & 1.5 & 1.2 & 1.0 & 1.0 & 1.2 & 1.3 & 1.4 & 1.5 & 1.5 \\
\hline Financial and capital account & 8.6 & 8.4 & 2.2 & 6.4 & 5.8 & 5.7 & 5.8 & 5.7 & 5.7 & 5.7 \\
\hline Direct investment & 6.2 & 6.9 & 4.6 & 4.1 & 4.6 & 4.5 & 4.4 & 4.4 & 4.4 & 4.4 \\
\hline Capital flows & 2.3 & 1.5 & -2.6 & 2.3 & 1.2 & 1.2 & 1.4 & 1.3 & 1.3 & 1.2 \\
\hline Public sector & 0.0 & 0.0 & 1.0 & 1.0 & 0.2 & 0.5 & 0.8 & 0.8 & 0.9 & 0.8 \\
\hline Private net capital & 2.3 & 1.4 & -3.6 & 1.3 & 1.1 & 0.7 & 0.6 & 0.5 & 0.5 & 0.4 \\
\hline Errors and omissions & 0.8 & -0.1 & 0.0 & -0.7 & 0.0 & 0.0 & 0.0 & 0.0 & 0.0 & 0.0 \\
\hline Change in net reserves (increase -) & -3.2 & 1.1 & -0.2 & -1.6 & -1.0 & -0.7 & -0.7 & -0.6 & -0.5 & -0.5 \\
\hline \multicolumn{11}{|l|}{ Memorandum items: } \\
\hline GDP deflator & 9.4 & 12.4 & 8.2 & 7.8 & 5.8 & 7.2 & 6.0 & 5.1 & 4.5 & 4.3 \\
\hline CPI (avg) & 9.4 & 13.4 & 7.8 & 5.7 & 6.0 & 7.0 & 6.0 & 5.0 & 4.2 & 4.0 \\
\hline $\mathrm{CPI}(\mathrm{eop})$ & 10.8 & 13.9 & 4.0 & 5.8 & 7.5 & 6.5 & 5.5 & 4.5 & 4.0 & 4.0 \\
\hline Net international reserves (millions of US\$) & 4,114 & 3,799 & 4,066 & 4,627 & 5,027 & 5,327 & 5,627 & 5,902 & 6,152 & 6,402 \\
\hline
\end{tabular}

Sources: Central Bank of Costa Rica; and Fund staff estimates.

1/ External current account deficit. 
Table 10. Costa Rica: Banking Sector Indicators

\begin{tabular}{|c|c|c|c|c|c|c|c|c|c|c|c|c|c|c|}
\hline \multicolumn{15}{|c|}{ (In percent) } \\
\hline & Mar & Jun & Sep & $\mathrm{Dec}$ & Mar & Jun & Sep & Dec & Mar & Jun & Sep & Dec & Jan & Feb \\
\hline & \multicolumn{4}{|c|}{2008} & \multicolumn{4}{|c|}{2009} & \multicolumn{4}{|c|}{2010} & \multicolumn{2}{|c|}{2011} \\
\hline \multicolumn{15}{|l|}{ Capitalization } \\
\hline Risk-adjusted capital ratio & 15.5 & 14.7 & 14.5 & 15.1 & 15.2 & 15.4 & 15.4 & 16.0 & 16.5 & 16.4 & 16.8 & 17.3 & 17.2 & 17.5 \\
\hline Capital-to-assets ratio & 12.8 & 12.8 & 12.8 & 13.3 & 13.3 & 13.5 & 13.7 & 13.9 & 14.3 & 14.5 & 14.9 & 14.8 & 14.7 & 14.9 \\
\hline \multicolumn{15}{|l|}{ Asset quality } \\
\hline Nonperforming loans to total loans & 1.2 & 1.1 & 1.2 & 1.5 & 1.8 & 2.0 & 2.1 & 2.0 & 3.1 & 2.2 & 2.0 & 1.8 & 1.9 & 1.8 \\
\hline Non-income generating assets to total assets & 16.6 & 17.0 & 18.1 & 18.2 & 19.1 & 18.9 & 19.0 & 18.6 & 19.6 & 18.7 & 18.3 & 17.4 & 17.5 & 17.3 \\
\hline Foreclosed assets to total assets & 0.2 & 0.2 & 0.2 & 0.3 & 0.4 & 0.4 & 0.5 & 0.6 & 0.6 & 0.7 & 0.8 & 0.8 & 0.8 & 0.8 \\
\hline Loan loss provisions to total loans & 1.8 & 1.7 & 1.7 & 1.8 & 1.9 & 1.9 & 2.0 & 1.9 & 2.1 & 2.1 & 1.9 & 1.8 & 1.8 & 1.8 \\
\hline \multicolumn{15}{|l|}{ Management } \\
\hline Administrative expenses to total assets & 4.8 & 4.6 & 4.5 & 4.4 & 4.3 & 4.3 & 4.2 & 4.1 & 4.1 & 4.1 & 4.2 & 4.3 & 4.3 & 4.3 \\
\hline Noninterest expenses to gross income & 77.2 & 79.6 & 82.2 & 79.3 & 78.9 & 77.4 & 75.7 & 76.8 & 81.6 & 85.9 & 86.9 & 85.0 & 84.3 & 84.3 \\
\hline Total expenses to total revenues & 90.6 & 91.0 & 91.7 & 92.5 & 93.0 & 93.5 & 93.7 & 95.2 & 96.5 & 97.2 & 97.2 & 96.2 & 95.9 & 95.8 \\
\hline \multicolumn{15}{|l|}{ Profitability } \\
\hline Return on assets (ROA) & 1.5 & 1.6 & 1.7 & 1.8 & 1.7 & 1.6 & 1.5 & 1.1 & 1.0 & 1.0 & 1.0 & 1.2 & 1.2 & 1.2 \\
\hline Return on equity (ROE) & 11.8 & 12.2 & 13.4 & 14.3 & 14.3 & 12.4 & 11.5 & 8.7 & 7.6 & 7.2 & 7.2 & 8.3 & 8.8 & 8.9 \\
\hline Interest margin to gross income & 34.0 & 29.4 & 25.6 & 20.8 & 20.4 & 20.8 & 21.7 & 20.7 & 17.5 & 14.4 & 14.4 & 16.6 & 17.5 & 17.6 \\
\hline \multicolumn{15}{|l|}{ Liquidity } \\
\hline Liquid assets to total short-term liabilities & 87.5 & 84.6 & 80.1 & 83.0 & 94.9 & 101.2 & 99.6 & 93.4 & 93.2 & 91.1 & 93.6 & 90.1 & 90.8 & 90.8 \\
\hline Liquid assets to total assets & 32.5 & 29.7 & 27.4 & 27.7 & 30.0 & 31.1 & 30.7 & 30.6 & 31.4 & 30.6 & 30.6 & 30.7 & 31.0 & 31.1 \\
\hline Loans to deposits & 103.1 & 107.3 & 109.8 & 109.7 & 101.9 & 98.6 & 98.4 & 98.9 & 97.1 & 95.8 & 97.2 & 97.8 & 96.9 & 96.6 \\
\hline Liquid assets to deposits & 48.5 & 44.6 & 41.0 & 42.1 & 43.7 & 44.8 & 43.7 & 43.9 & 44.8 & 42.6 & 43.3 & 43.8 & 44.1 & 44.2 \\
\hline \multicolumn{15}{|l|}{ Sensitivity to market risk } \\
\hline Net open FX position to capital & 19.0 & 21.7 & 19.5 & 20.4 & 22.8 & 22.9 & 26.4 & 25.4 & 22.2 & 21.7 & 17.3 & 18.8 & 18.2 & 17.3 \\
\hline \multicolumn{15}{|l|}{ Other } \\
\hline Financial margin $1 /$ & 7.8 & 7.6 & 7.7 & 7.9 & 8.0 & 8.3 & 7.9 & 7.7 & 7.8 & 8.0 & 8.1 & 8.2 & 8.2 & 8.3 \\
\hline Credit growth (over a year ago) & 38.3 & 40.0 & 33.5 & 27.8 & 20.6 & 13.1 & 10.4 & 4.5 & 1.3 & 2.5 & 0.2 & 4.2 & 5.4 & 5.2 \\
\hline Deposit growth (over a year ago) & 22.4 & 23.8 & 21.3 & 25.4 & 21.9 & 23.1 & 24.6 & 15.9 & 6.3 & 5.4 & 0.3 & 5.4 & 7.5 & 7.7 \\
\hline
\end{tabular}

Source: Superintendency of Banks.

1/ Difference between implicit loan and deposit rates. 
Table 11. Costa Rica: External Debt Sustainability Framework, 2006-2016

(In percent of GDP, unless otherwise indicated)

\begin{tabular}{|c|c|c|c|c|c|c|c|c|c|c|c|c|c|c|}
\hline & \multicolumn{4}{|c|}{ Actual } & \multirow{2}{*}{$\frac{\text { Est. }}{2010}$} & & & \multicolumn{6}{|c|}{ Projections } & \multirow{2}{*}{$\begin{array}{l}\text { Debt-stabilizing } \\
\text { Non-interest } \\
\text { Current Account 6 }\end{array}$} \\
\hline & 2006 & 2007 & 2008 & 2009 & & & & 2011 & 2012 & 2013 & 2014 & 2015 & 2016 & \\
\hline Baseline: External debt & 31.9 & 32.1 & 30.5 & 28.0 & 25.2 & & & 24.0 & 24.2 & 25.0 & 25.9 & 26.9 & 27.9 & -3.9 \\
\hline Change in external debt & -2.0 & 0.2 & -1.6 & -2.6 & -2.7 & & & -1.3 & 0.2 & 0.8 & 0.9 & 1.0 & 1.0 & \\
\hline Identified external debt-creating flows $(4+8+9+10)$ & -5.8 & -5.5 & -1.4 & -2.0 & -5.5 & & & -1.2 & -0.2 & 0.1 & 0.2 & 0.3 & 0.2 & \\
\hline Current account deficit, excluding interest payments & 3.4 & 4.6 & 8.2 & 0.9 & 2.9 & & & 4.2 & 4.4 & 4.5 & 4.3 & 3.8 & 3.5 & \\
\hline Deficit in balance of goods and services & 6.1 & 4.8 & 9.4 & -0.5 & 3.3 & & & 3.9 & 4.2 & 4.6 & 4.7 & 4.5 & 4.4 & \\
\hline Exports & 49.2 & 48.8 & 45.7 & 42.5 & 37.5 & & & 37.7 & 38.2 & 38.6 & 39.2 & 39.9 & 40.5 & \\
\hline Imports & 55.3 & 53.6 & 55.1 & 42.0 & 40.8 & & & 41.6 & 42.4 & 43.2 & 43.9 & 44.4 & 44.9 & \\
\hline Private sector debt creating flows & -0.4 & 1.2 & 0.1 & -3.2 & -1.8 & & & -0.5 & 0.2 & 0.4 & 0.5 & 0.6 & 0.6 & \\
\hline Net non-debt creating capital inflows (negative) & -6.5 & -7.2 & -7.0 & -4.6 & -4.1 & & & -4.6 & -4.5 & -4.4 & -4.4 & -4.4 & -4.4 & \\
\hline Automatic debt dynamics $1 /$ & -2.7 & -3.0 & -2.6 & 1.7 & -4.4 & & & -0.3 & -0.4 & -0.4 & -0.2 & 0.3 & 0.6 & \\
\hline Contribution from nominal interest rate & 1.2 & 1.6 & 1.2 & 1.0 & 0.7 & & & 0.6 & 0.6 & 0.6 & 0.9 & 1.4 & 1.8 & \\
\hline Contribution from real GDP growth & -2.6 & -2.2 & -0.8 & 0.4 & -1.0 & & & -1.0 & -1.0 & -1.0 & -1.1 & -1.1 & -1.2 & \\
\hline Contribution from price and exchange rate changes $2 /$ & -1.2 & -2.4 & -3.0 & 0.2 & -4.2 & & & & & & & & & \\
\hline Residual, incl. change in gross foreign assets $3 /$ & 3.9 & 5.7 & -0.2 & -0.5 & 2.8 & & & -0.1 & 0.5 & 0.6 & 0.7 & 0.7 & 0.7 & \\
\hline External debt-to-exports ratio (in percent) & 64.9 & 65.7 & 66.8 & 65.8 & 67.3 & & & 63.6 & 63.4 & 64.7 & 65.9 & 67.4 & 68.8 & \\
\hline Gross external financing need (in billions of US dollars) $4 /$ & 5.8 & 6.9 & 10.3 & 8.5 & 6.6 & & & 7.7 & 8.7 & 9.6 & 10.8 & 11.8 & 13.2 & \\
\hline In percent of GDP & 25.9 & 26.1 & 34.4 & 29.2 & 18.4 & & & 19.2 & 20.2 & 21.1 & 22.4 & 23.4 & 24.9 & \\
\hline Scenario with key variables at their historical averages $5 /$ & & & & & & & & 24.4 & 23.4 & 22.2 & 21.0 & 19.7 & 18.5 & -5.5 \\
\hline & & & & & & $\begin{array}{l}10 \text {-Year } \\
\text { Historical }\end{array}$ & $\begin{array}{c}10-Y e a r \\
\text { Standard }\end{array}$ & & & & & & & \\
\hline Key Macroeconomic Assumptions Underlying Baseline & & & & & & Average & Deviation & & & & & & & \\
\hline Real GDP growth (in percent) & 8.8 & 7.9 & 2.7 & -1.3 & 4.2 & 4.3 & 3.1 & 4.3 & 4.4 & 4.5 & 4.5 & 4.5 & 4.5 & \\
\hline GDP deflator in U.S. dollars (change in percent) & 3.7 & 8.3 & 10.4 & -0.7 & 17.5 & 4.2 & 6.1 & 7.6 & 2.8 & 1.5 & 0.9 & 0.3 & 0.3 & \\
\hline Nominal external interest rate (in percent) & 3.9 & 5.9 & 4.1 & 3.3 & 3.1 & 4.4 & 0.9 & 2.8 & 2.5 & 2.8 & 3.7 & 5.7 & 6.7 & \\
\hline Growth of exports (US dollar terms, in percent) & 13.9 & 16.1 & 6.1 & -8.9 & 7.9 & 6.1 & 9.6 & 12.9 & 8.7 & 7.1 & 7.2 & 6.7 & 6.3 & \\
\hline Growth of imports (US dollar terms, in percent) & 15.7 & 13.3 & 16.6 & -25.4 & 18.8 & 8.1 & 13.6 & 14.5 & 9.3 & 8.0 & 7.1 & 6.0 & 5.9 & \\
\hline Current account balance, excluding interest payments & -3.4 & -4.6 & -8.2 & -0.9 & -2.9 & -3.6 & 1.9 & -4.2 & -4.4 & -4.5 & -4.3 & -3.8 & -3.5 & \\
\hline Net non-debt creating capital inflows & 6.5 & 7.2 & 7.0 & 4.6 & 4.1 & 4.8 & 1.5 & 4.6 & 4.5 & 4.4 & 4.4 & 4.4 & 4.4 & \\
\hline
\end{tabular}

$1 /$ Derived as $[r-g-\rho(1+g)+\varepsilon \alpha(1+r)](1+g+\rho+g \rho)$ times previous period debt stock, with $r=$ nominal effective interest rate on external debt; $\rho=$ change in domestic GDP deflator in US dollar terms, $g=$ real GDP growth rate,

$\varepsilon=$ nominal appreciation (increase in dollar value of domestic currency), and $\alpha=$ share of domestic-currency denominated debt in total external debt.

$2 /$ The contribution from price and exchange rate changes is defined as $[-\rho(1+\mathrm{g})+\varepsilon \alpha(1+\mathrm{r}) y(1+\mathrm{g}+\rho+\mathrm{g} \rho)$ times previous period debt stock. $\rho$ increases with an appreciating domestic currency $(\varepsilon>0)$ and rising inflation (based on GDP deflator). 3/ For projection, line includes the impact of price and exchange rate changes.

4/ Defined as current account deficit, plus amortization on medium- and long-term debt, plus short-term debt at end of previous period.

5/ The key variables include real GDP growth; nominal interest rate; dollar deflator growth; and both non-interest current account and non-debt inflows in percent of GDP.

6/ Long-run, constant balance that stabilizes the debt ratio assuming that key variables (real GDP growth, nominal interest rate, dollar deflator growth, and non-debt inflows in percent of GDP) remain at their levels of the last projection year. 


\section{Figure 7. Costa Rica: External Debt Sustainability: Bound Tests 1/ (External debt in percent of GDP)}

Baseline and historical scenarios

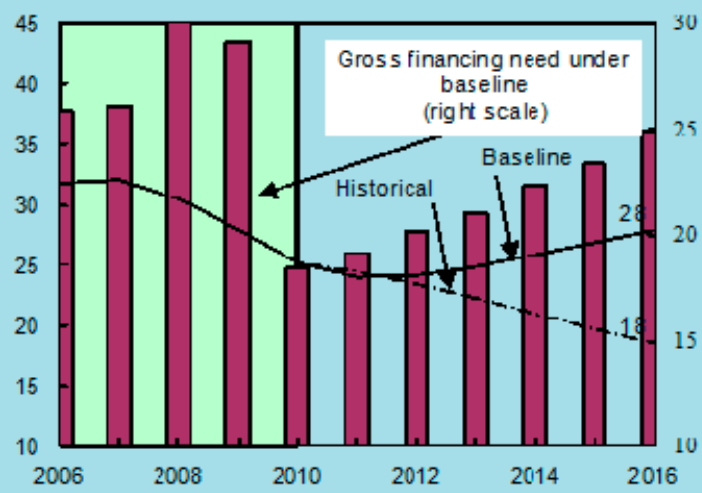

Growth shock (in percent per year)

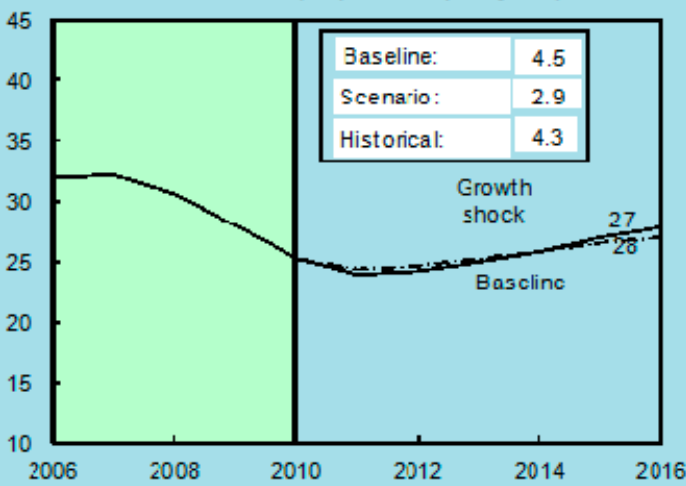

Combined shock 2/

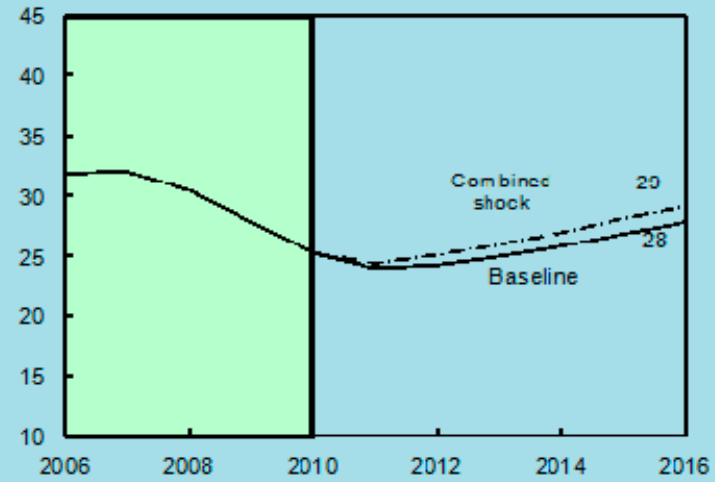

Interest rate shock (in percent)

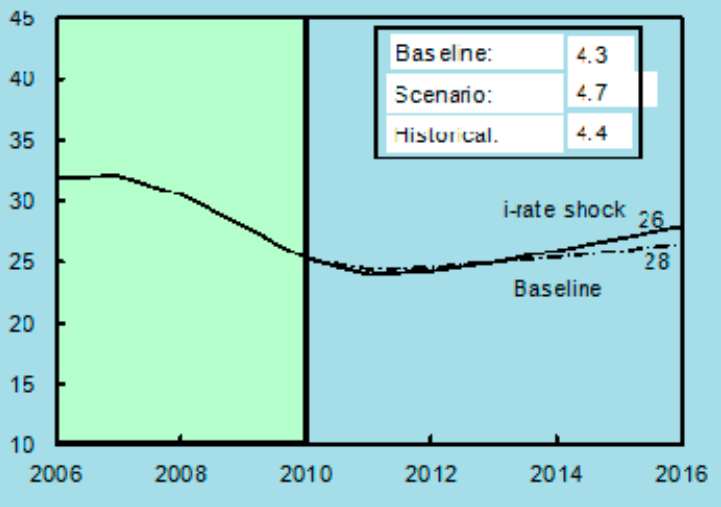

Non-interest current account shock (In percent of GUP)

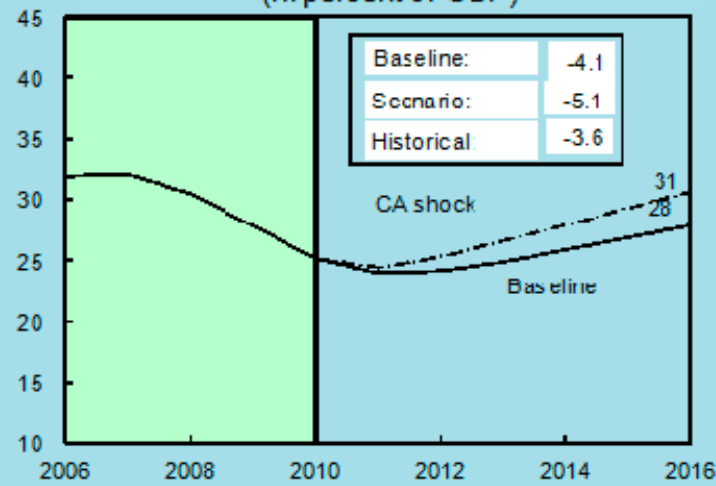

Sources: International Monctary Fund, Country desk data, and staffestimates.

$1 /$ Shaded areas represent actual data. Individual shocks are permanent one-ralf standard deviation shocks. Figures in the boxes represent average projections for the respective variables in the baseline and secenerio being presented. Ten yearhistorical average for the variable is also showr.

$2 / \mathrm{P} \in \mathrm{rmanent} 1 / 4$ standard dev ation shocks applied to real interest rate, growth rate, and current accourt balance.

$3 /$ One-time real depreciation of 30 percent occurs in 2010. 
Table 12. Costa Rica: Combined Public Sector Debt Sustainability Framework, 2006-2016

(In percent of GDP, unless otherwise indicated)

\begin{tabular}{|c|c|c|c|c|c|c|c|c|c|c|c|c|c|c|}
\hline & \multicolumn{4}{|c|}{ Actual } & \multirow{2}{*}{$\begin{array}{r}\text { Est. } \\
2010\end{array}$} & & & \multicolumn{6}{|c|}{ Projections } & \multirow{2}{*}{$\begin{array}{c}\text { Debt- } \\
\text { Stabilizing } \\
\text { Primary } \\
\text { Balance } 9\end{array}$} \\
\hline & 2006 & 2007 & 2008 & 2009 & & & & 2011 & 2012 & 2013 & 2014 & 2015 & 2016 & \\
\hline Baseline: Public sector debt $1 /$ & 47.3 & 42.5 & 36.0 & 38.4 & 39.4 & & & 41.8 & 42.3 & 43.0 & 43.8 & 44.8 & 46.0 & -0.2 \\
\hline Of which: foreign-currency denominated & 18.3 & 13.5 & 11.9 & 11.7 & 11.3 & & & 11.5 & 11.7 & 11.5 & 11.3 & 11.1 & 11.0 & \\
\hline Change in public sector debt & -3.8 & -4.8 & -6.4 & 2.4 & 0.9 & & & 2.4 & 0.5 & 0.7 & 0.8 & 1.0 & 1.1 & \\
\hline Identified debt-creating flows $(4+7+12)$ & -7.3 & -9.1 & -4.5 & 1.9 & 1.3 & & & 2.0 & -0.2 & 0.2 & 0.3 & 0.6 & 0.7 & \\
\hline Primary deficit & -3.2 & -4.3 & -2.6 & 1.7 & 3.1 & & & 2.9 & 1.3 & 1.3 & 1.3 & 1.3 & 1.3 & \\
\hline Revenue and grants & 22.3 & 23.4 & 23.6 & 22.5 & 22.2 & & & 22.5 & 24.3 & 24.5 & 24.7 & 24.9 & 25.0 & \\
\hline Primary (noninterest) expenditure & 19.1 & 19.1 & 20.9 & 24.2 & 25.4 & & & 25.5 & 25.6 & 25.9 & 26.0 & 26.1 & 26.2 & \\
\hline Automatic debt dynamics $2 /$ & -4.1 & -4.8 & -1.8 & 0.2 & -1.8 & & & -0.9 & -1.5 & -1.2 & -1.0 & -0.7 & -0.6 & \\
\hline Contribution from interest rate/growth differential $3 /$ & -4.9 & -4.2 & -3.3 & 0.0 & -1.8 & & & -0.9 & -1.5 & -1.2 & -1.0 & -0.7 & -0.6 & \\
\hline Of which: contribution from real interest rate & -1.2 & -1.0 & -2.3 & -0.4 & -0.4 & & & 0.6 & 0.2 & 0.6 & 0.8 & 1.2 & 1.3 & \\
\hline Of which: contribution from real GDP growth & -3.7 & -3.2 & -1.0 & 0.4 & -1.4 & & & -1.5 & -1.6 & -1.7 & -1.8 & -1.8 & -1.9 & \\
\hline Contribution from exchange rate depreciation $4 /$ & 0.8 & -0.6 & 1.4 & 0.2 & -1.1 & & & & $\ldots$ & $\ldots$ & & & 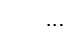 & \\
\hline Other identified debt-creating flows & 0.0 & 0.0 & 0.0 & 0.0 & 0.0 & & & 0.0 & 0.0 & 0.0 & 0.0 & 0.0 & 0.0 & \\
\hline Privatization receipts (negative) & 0.0 & 0.0 & 0.0 & 0.0 & 0.0 & & & 0.0 & 0.0 & 0.0 & 0.0 & 0.0 & 0.0 & \\
\hline Recognition of implicit or contingent liabilities & 0.0 & 0.0 & 0.0 & 0.0 & 0.0 & & & 0.0 & 0.0 & 0.0 & 0.0 & 0.0 & 0.0 & \\
\hline Other (specify, e.g. bank recapitalization) & 0.0 & 0.0 & 0.0 & 0.0 & 0.0 & & & 0.0 & 0.0 & 0.0 & 0.0 & 0.0 & 0.0 & \\
\hline Residual, including asset changes $5 /$ & 3.5 & 4.2 & -2.0 & 0.5 & -0.4 & & & 0.4 & 0.6 & 0.5 & 0.5 & 0.4 & 0.4 & \\
\hline Public sector debt-to-revenue ratio $1 /$ & 212.3 & 181.3 & 152.9 & 171.0 & 177.3 & & & 185.6 & 174.0 & 175.3 & 177.2 & 180.3 & 184.0 & \\
\hline $\begin{array}{l}\text { Gross financing need } 6 / \\
\text { In billions of U.S. dollars }\end{array}$ & $\begin{array}{l}0.7 \\
0.2\end{array}$ & $\begin{array}{l}-1.2 \\
-0.3\end{array}$ & $\begin{array}{l}-0.2 \\
-0.1\end{array}$ & $\begin{array}{l}4.0 \\
1.2\end{array}$ & $\begin{array}{l}5.5 \\
2.0\end{array}$ & & & $\begin{array}{l}5.6 \\
2.3\end{array}$ & $\begin{array}{l}4.2 \\
1.8\end{array}$ & $\begin{array}{l}4.1 \\
1.9\end{array}$ & $\begin{array}{l}4.1 \\
2.0\end{array}$ & $\begin{array}{l}4.2 \\
2.1\end{array}$ & $\begin{array}{l}4.3 \\
2.3\end{array}$ & \\
\hline Scenario with key variables at their historical averages 71 & & & & & & & & 35.6 & 32.3 & 28.9 & 25.6 & 22.4 & 19.4 & -1.0 \\
\hline Scenario with no policy change (constant primary balance) in $2010-2016$ & & & & & & & & 41.6 & 43.9 & 46.4 & 49.0 & 51.9 & 54.9 & -0.3 \\
\hline & & & & & & 10-Year & 10-Year & & & & & & & \\
\hline Key Macroeconomic and Fiscal Assumptions Underlying Baseline & & & & & & $\begin{array}{l}\text { Historical } \\
\text { Average } \\
\end{array}$ & $\begin{array}{l}\text { Standard } \\
\text { Deviation } \\
\end{array}$ & & & & & & & \\
\hline Real GDP growth (in percent) & 8.8 & 7.9 & 2.7 & -1.3 & 4.2 & 4.3 & 3.1 & 4.3 & 4.4 & 4.5 & 4.5 & 4.5 & 4.5 & \\
\hline Average nominal interest rate on public debt (in percent) $8 /$ & 9.2 & 7.7 & 6.6 & 6.7 & 6.9 & 8.3 & 1.2 & 7.6 & 7.6 & 7.3 & 7.3 & 7.4 & 7.4 & \\
\hline Average real interest rate (nominal rate minus change in GDP deflator, in percent) & -1.8 & -1.7 & -5.8 & -1.4 & -0.8 & -1.5 & 1.9 & 1.9 & 0.7 & 1.7 & 2.3 & 3.1 & 3.3 & \\
\hline Nominal appreciation (increase in US dollar value of local currency, in percent) & -4.1 & 4.0 & -10.3 & -1.7 & 11.3 & -4.3 & 7.1 & & & & & & & \\
\hline Inflation rate (GDP deflator, in percent) & 11.0 & 9.4 & 12.4 & 8.2 & 7.8 & 9.7 & 1.6 & 5.7 & 6.9 & 5.6 & 5.0 & 4.3 & 4.1 & \\
\hline Growth in real primary spending of combined public sector (in percent) & 5.7 & 11.0 & 14.6 & 11.6 & 13.0 & 8.2 & 4.6 & 4.3 & 4.9 & 5.1 & 5.1 & 5.0 & 5.1 & \\
\hline
\end{tabular}

$1 /$ The public sector comprises the central government decentralized entities, public enterprises (excluding ICE), and the central bank

2/ Derived as $[(r-\pi(1+g)-g+\alpha \varepsilon(1+r)] /(1+g+\pi+g \pi))$ times previous period debt ratio, with $r=$ interest rate; $\pi=$ growth rate of GDP deflator; $g=$ real GDP growth rate; $\alpha=$ share of foreign-currency denominated debt,

and $\varepsilon=$ nominal exchange rate depreciation (measured by increase in local currency value of U.S. dollar).

$3 /$ The real interest rate contribution is derived from the denominator in footnote $2 /$ as $r-\pi(1+g)$ and the real growth contribution as $-g$.

$4 /$ The exchange rate contribution is derived from the numerator in footnote $2 /$ as $\alpha \varepsilon(1+r)$.

6/ For projections, this line includes exchange rate changes.

7/ The key variables include real GDP growth; real interest rate; and primary balance in percent of GDP.

9/ Assumes that key variables (real GDP growth, real interest rate, and other identified debt-creating flows) remain at the level of the last projection year. 
Figure 8. Costa Rica: Public Debt Sustainability: Bound Tests 1/ (Public debt in percent of GDP)

Baseline and historical scenarios

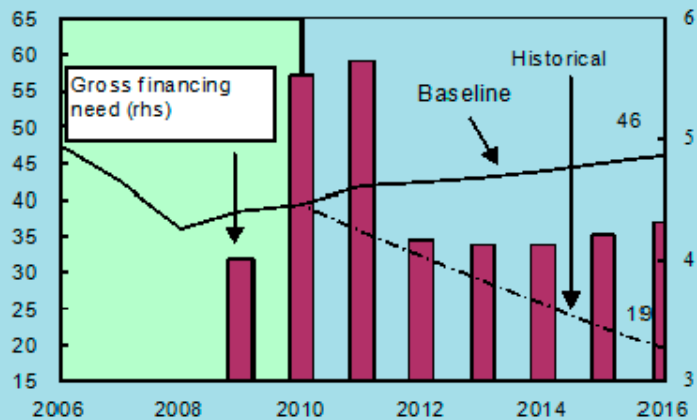

Growth shock (in percent per year)

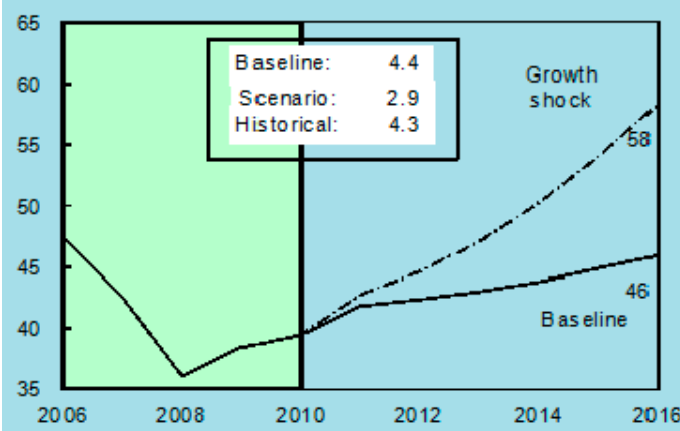

Combined shock 2/

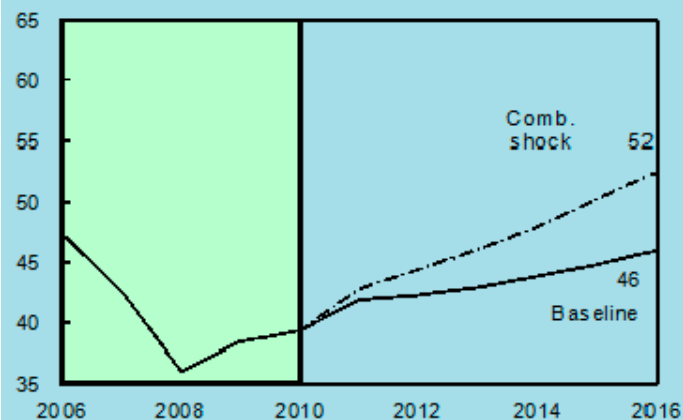

Interest rate shock (in percent)

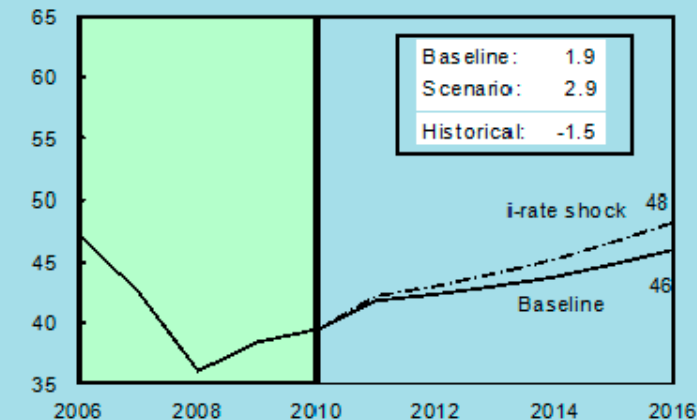

Primary balance shock (percent of GDP) and no policy change (constant primary balance)

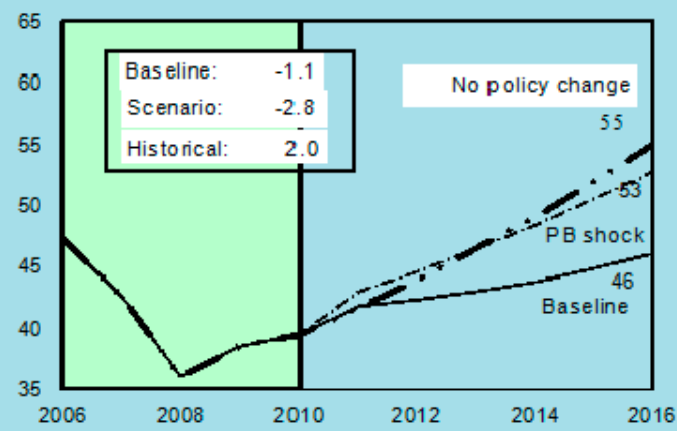

Real depreciation and contingent liabilities shocks

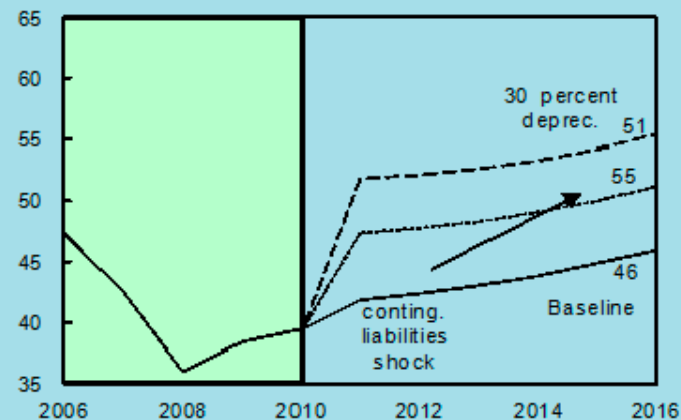

Sources: International Monetary Fund, country desk data, and staff es timates.

$1 /$ Shaded areas represent actual data. Individual shocks are permanent one-half standard deviation shocks. Figures in the boxes represent average projections forthe respectivevariables in the bas eline and scenario being presented. Ten-year historical average for the variable is also shown.

$2 /$ Permanent $1 / 4$ standard deviation shocks applied to real interest rate, growth rate, and primary balance.

$3 /$ One-time real depreciation of 30 p ercent and 10 perc ent of GDP shock to conting ent liabilities occur in 2009, with real depreciation defined as nominal depreciation (measured by percentage $f$ all in dollar value of local currency) minus domestic inflation (based on $G D P$ deflator). 


\section{INTERNATIONAL MONETARY FUND}

COSTA RICA

\section{Article IV Consultation-Informational Annex}

Prepared by the Western Hemisphere Department

(In consultation with other departments)

May 11, 2011

Contents

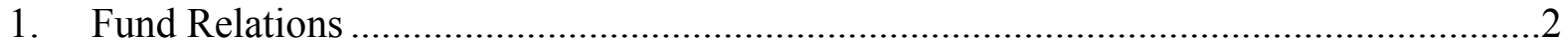

2. Relations with the World Bank and Bank-Fund Collaboration under the JMAP.............4

3. Relations with the Inter-American Development Bank ...........................................

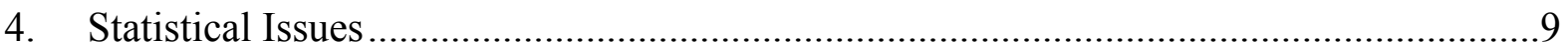




\section{RELATIONS WITH THE FUND \\ As of March 31, 2011}

I. Membership Status: Joined: January 08, 1946, Article VIII.

II. General Resources Account:

Quota

Fund holdings of currency

Reserve Tranche Position

III. SDR Department:

Net cumulative allocation

Holdings

\author{
SDR Million \\ 164.10 \\ 144.09 \\ 20.02
}

$\begin{array}{rr}\text { SDR } & \text { \%Allocation } \\ \text { Million } & 100.00 \\ 156.53 & 84.70 \\ 132.58 & \end{array}$

IV. Outstanding Purchases and Loans: None

V. Latest Financial Arrangements:

$\begin{array}{rccc}\begin{array}{c}\text { Type } \\ \text { Stand-By }\end{array} & \begin{array}{c}\text { Approval } \\ \text { date }\end{array} & \begin{array}{c}\text { Expiration } \\ \text { date }\end{array} & \begin{array}{c}\text { Amount approved } \\ \text { (SDR million) }\end{array} \\ \text { Stand-By } 11,2009 & \text { Jul 10,2010 } & 492.30 \\ \text { Stand-By } & \text { Apr 29,1995 } & \text { Feb 28, 1997 } & 52.00 \\ & \text { Apr 1993 } & \text { Feb 18, 1994 } & 21.04\end{array}$

VI. Projected Payments to Fund: (SDR million; based on existing use of resources and present holdings of SDRs):

\begin{tabular}{lcccccc} 
& Overdue & \multicolumn{5}{c}{ Forthcoming } \\
& & $\underline{2011}$ & $\underline{2012}$ & $\underline{2013}$ & $\underline{2014}$ & $\underline{2015}$ \\
Principal & 0.00 & 0.00 & 0.00 & 0.00 & 0.00 & 0.00 \\
Charges/Interes & 0.00 & 0.08 & 0.11 & 0.11 & 0.11 & 0.11 \\
$\mathrm{t}$ & & & & & & \\
Total & 0.00 & 0.08 & 0.11 & 0.11 & 0.11 & 0.11
\end{tabular}

VII Exchange Rate Arrangement: Costa Rica's current exchange arrangement is classified as other managed arrangement. Since October 2006, the de jure exchange rate arrangement has been a crawling band with an increasing width. The ceiling and floor of the band have been adjusted several times, most recently in January 2009, when the crawl rate of the band's ceiling has been set at 0.20 colones (previously 0.06 colones) per business day. The floor of the band has been flat since July 2008. As of May 11, 2011, the intervention buying and selling exchange rates were 500.00 and 679.65 colones per 
U.S. dollar respectively. Costa Rica maintains an exchange system free of restrictions on the making of payments and transfers for current international transactions.

VIII. Last Article IV Consultation: Concluded on September 23, 2009 (Country Report No. 09/303). The next Article IV consultation will take place in accordance with the July 15, 2002 decision on consultation cycles.

IX. FSAP Participation and ROSCs Assessments: The FSAP took place in October and December 2001, and was updated in February 2008. A data ROSC took place in July 2001 with a reassessment in April 2009. A fiscal ROSC took place in April 2006.

\section{Recent Technical Assistance:}

\begin{tabular}{|c|c|c|}
\hline Department & Dates & Purpose \\
\hline $\begin{array}{l}\text { STA, } \\
\text { CAPTAC }\end{array}$ & $\begin{array}{l}\text { February } 2011 \\
\text { September } 2010 \\
\text { February } 2010 \\
\text { December } 2009 \\
\text { January } 2011 \\
\text { October } 2010 \\
\text { February } 2008\end{array}$ & $\begin{array}{l}\text { Regional Project on Harmonization of External Sector Statistics, } \\
\text { specifically, Statistics of the BOP, International Investment Position, } \\
\text { International Reserves, Foreign Currency Liquidity, and Foreign Debt } \\
\text { Government Finance Statistics } \\
\text { Monetary and Financial Statistics }\end{array}$ \\
\hline $\begin{array}{l}\text { MCM, } \\
\text { CAPTAC }\end{array}$ & $\begin{array}{l}\text { April } 2011 \\
\text { December } 2010 \\
\text { March } 2010 \\
\text { November } 2010 \\
\text { August } 2010 \\
\text { December } 2008 \\
\text { November } 2008 \\
\text { August } 2008 \\
\text { October } 2008 \\
\text { September } 2008\end{array}$ & $\begin{array}{l}\text { Monetary Policy Implementation: Liquidity and Foreign Exchange } \\
\text { Management } \\
\text { Reorganization of SUGEF and Modernization of Supervisory Practices } \\
\text { Supervision of Foreign Exchange Risk and Foreign Exchange Operations } \\
\text { Central Bank FX Intervention }\end{array}$ \\
\hline $\begin{array}{l}\text { FAD, } \\
\text { CAPTAC }\end{array}$ & $\begin{array}{l}\text { November } 2010 \\
\text { May } 2010 \\
\text { February } 2010 \\
\text { September } 2009 \\
\text { October } 2009\end{array}$ & $\begin{array}{l}\text { Tax and Customs Administration } \\
\text { Public Finance Management }\end{array}$ \\
\hline LEG & August 2010 & AML/CFT Legal and Supervisory Framework \\
\hline
\end{tabular}

XI. Resident Representative: Fernando L. Delgado is the regional resident representative in Central America, Panama and the Dominican Republic. 


\section{RELATIONS WITH THE WORLD BANK AND BANK-FUND COLLABORATION UNDER THE JMAP}

1. The IMF's Costa Rica team led by Mr. Piñón (mission chief) has met on various occasions with the World Bank's Costa Rica team led by Mr. Lopez (lead economist and PREM sector leader) to discuss macroeconomic challenges, identify macrocritical structural reforms, and coordinate the two teams' work for the period March 2011-February 2012.

2. The teams have agreed that Costa Rica's main macroeconomic challenges are to safeguard fiscal sustainability, increase the effectiveness of monetary policy, maintain financial sector stability and enhance competitiveness.

3. The teams have also discussed the risks to Costa Rica's inflation outlook stemming from higher global commodity prices, and the appropriate policy mix to contain second round effects.

4. Based on the shared assessment of macroeconomic challenges, the teams have identified 4 structural reform areas as macrocritical:

- Fiscal consolidation. Costa Rica's fiscal position deteriorated due to larger than expected revenue losses during the global crisis and higher-than-anticipated increases in current spending. The priority now is to roll back the fiscal expansion of recent years and limit the risks to fiscal sustainability. Approval of a tax reform is critical, but there is also a need for a strategy to reduce current spending as a percent of GDP.

- Monetary policy framework. The transition to inflation targeting and greater exchange rate flexibility should be accelerated in order to lock in low inflation achieved recently and limit currency appreciation pressures.

- Financial sector stability. Progress has been made in adopting risk-based financial supervision. Looking ahead, approval of legislation on consolidated supervision, deposit insurance and banking resolution will be critical to bring the regulatory framework up to international best practices.

- Competitiveness. The country is making progress in addressing issues of universal coverage and quality in secondary education, and is seeking to develop its scientific and technological capabilities, which would help position Costa Rica as a knowledge economy. There is also a high level commitment to improving the business environment and removing burdensome red tape. Given the sizable investments required to upgrade infrastructure and a tight fiscal situation, the government is seeking to create the institutional conditions to engage the private sector in financing, construction and management of infrastructure projects (public-private partnerships). The government 
has already begun to open the insurance, electricity and telecommunication sectors to private investments.

\section{The teams agreed the following division of labor:}

- Fiscal consolidation. The Fund will continue to provide policy recommendations on macro-fiscal issues, including the overall strategy of fiscal consolidation and the tax reform. The government has also requested World Bank technical assistance to support the use of public-private partnerships as a vehicle to finance key infrastructure projects.

- Monetary policy framework. The Fund will continue to provide policy recommendations regarding the transition to inflation targeting and a more flexible exchange rate regime.

- Financial sector stability. The Bank and the Fund will cooperate as necessary in assisting the country in implementing the FSAP recommendations.

- Competitiveness. The Bank will continue to work with the government on policy recommendations in key areas. In terms of lending, the government has requested a project in higher education that is currently under preparation. The government has also requested technical assistance from IFC Advisory services to improve the investment climate.

\section{The teams have the following requests for information from their counterparts:}

- The Fund team requests to be kept informed of progress in the above macro-critical structural reform areas. Timing: when milestones are reached (and at least semiannually).

- The Bank team requests to be kept informed of the Fund's assessments of macroeconomic policies and prospects.

7. The attached table lists the teams' separate and joint work programs during March 2011-February 2012. 

World Bank and IMF Planned Activities in Macro-Critical Structural Reform
Areas, March 2011-February 2012

\begin{tabular}{|c|c|c|c|}
\hline Title & Products & $\begin{array}{c}\text { Provisional } \\
\text { Timing of Missions }\end{array}$ & $\begin{array}{c}\text { Expected } \\
\text { Delivery Date }\end{array}$ \\
\hline $\begin{array}{l}\text { World Bank Work } \\
\text { Program }\end{array}$ & $\begin{array}{l}\text { Country Partnership Strategy } \\
\text { International Investors Conference } \\
\text { with the Council of the Americas }\end{array}$ & $\begin{array}{l}\text { Preparatory work is } \\
\text { ongoing } \\
\text { June } 30,2011\end{array}$ & $\begin{array}{l}\text { Board Discussion is } \\
\text { expected in July } 2011 \\
\text { June } 30,2011\end{array}$ \\
\hline $\begin{array}{l}\text { IMF Work } \\
\text { Program }\end{array}$ & $\begin{array}{l}\text { Staff visit } \\
\text { Technical Assistance: } \\
\text { Tax revenue and Customs } \\
\text { Administration } \\
\text { Strengthening Medium-term } \\
\text { Expenditure Framework } \\
\text { Risk-based policies and procedures } \\
\text { for AML/CFT supervision } \\
\text { Liquidity management, macro } \\
\text { forecasting models and exchange rate } \\
\text { market (CAPTAC) } \\
\text { Improvements in National Accounts } \\
\text { Improvement in PPI and } \\
\text { import/export price indexes } \\
\text { Migration to the GFSM } 2001 \\
\text { analytical framework } \\
\text { Improvement in monetary and } \\
\text { financing statistics as part of regional } \\
\text { project } \\
\text { Improvement in external sector } \\
\text { statistics as part of regional project }\end{array}$ & $\begin{array}{l}\text { October } 2011 \\
2011-2012\end{array}$ & \\
\hline
\end{tabular}




\section{RELATIONS WITH THE INTER-AMERICAN DEVELOPMENT BANK}

1. Recent activities. The IBD's loan portfolio in Costa Rica has 8 sovereign guaranteed operations in execution, with an approved amount of US\$798.6 million. The available amount for disbursements is US\$697.3 million (87.3\% of the approved), and is concentrated in the areas of Transportation (49.0\%), Energy (33.6\%) and Water and Sanitation (11.7\%). The average age of the operations is 4.9 years. The IDB still has three operations pending legislative ratification: a program for water and sanitation, a cantonal road network program, and a sustainable tourism program. Disbursements of sovereign guaranteed operations during 2011 are expected to reach around US\$102.5 million, concentrated in the areas of Energy (57.1\%), Transportation (24.4\%) and Reform and Modernization of the State (18.0\%). Currently, there is one operation expected to be approved by the IDB during 2011, which is the program of Citizen Security (US\$132.4 million).

2. Future plans. The IDB is currently preparing the Country Strategy 2011-14, which is expected to be approved by June 2011. During the strategy period, the IDB intends to be involved mainly in the areas of Transportation, Energy, Citizen Security, Social Protection and Innovation.

Sovereign Guaranteed Operations (as of April 19, 2011) (In millions of U.S. dollars)

\begin{tabular}{lrrrr}
\hline & Approved & Disbursed & $\begin{array}{r}\text { Obligate } \\
\text { d }\end{array}$ & $\begin{array}{r}\text { Available } \\
\hline \text { Loans in execution }\end{array}$ \\
Tourism Program in Protected Areas & $\mathbf{7 9 8 . 6}$ & $\mathbf{1 0 1 . 3}$ & $\mathbf{0 . 0}$ & $\mathbf{6 9 7 . 3}$ \\
First Electric Power Sector Development & 19.0 & 0.0 & 0.0 & 19.0 \\
Program 2008-2011 & 250.0 & 15.8 & 0.0 & 234.2 \\
First Road Infrastructure Program & 300.0 & 18.1 & 0.0 & 281.9 \\
Cantonal Road Network Program & 60.0 & 0.0 & 0.0 & 60.0 \\
Water and Sanitation Program & 73.0 & 0.0 & 0.0 & 73.0 \\
Cadaster and Registry Regularization & 65.0 & 45.3 & 0.0 & 19.7 \\
Judiciary Modernization Program II & 22.4 & 21.8 & 0.0 & 0.6 \\
Sustainable Development of the Binational & 9.2 & 0.3 & 0.0 & 8.9 \\
Watershed Rio Sixaola & $\mathbf{3 4 . 8}$ & $\mathbf{7 . 1}$ & $\mathbf{0 . 1}$ & $\mathbf{2 7 . 6}$ \\
Nonreimbursable Technical Cooperations & $\mathbf{8 3 3 . 4}$ & $\mathbf{1 0 8 . 4}$ & $\mathbf{0 . 1}$ & $\mathbf{7 2 4 . 9}$ \\
Total & & & &
\end{tabular}




\section{Loan Disbursements (Sovereign Guaranteed Operations)}

(In millions of U.S. dollars)

\begin{tabular}{lrrrrrrrrr}
\hline & 2003 & 2004 & 2005 & 2006 & 2007 & 2008 & 2009 & 2010 & $2011^{*}$ \\
\hline Disbursements & 88.4 & 100.2 & 41.6 & 22.5 & 12.9 & 18.0 & 40.6 & 55.7 & 102.4 \\
Amortization & 93.1 & 110.2 & 208.8 & 78.4 & 81.4 & $289.3^{* *}$ & 46.0 & 45.3 & 64.2 \\
Interest and charges & 42.3 & 41.8 & 40.2 & 26.3 & 23.6 & 24.1 & 13.8 & 11.9 & 28.0 \\
Net cash flow & -47.0 & -51.8 & -207.4 & -82.2 & -92.1 & -295.4 & -19.2 & -1.5 & 10.2 \\
\hline
\end{tabular}

* Projections (January 2011).

**Includes an anticipated repayment of US\$200 million

\section{Lending Program for 2011 (Tentative)}

(In millions of U.S. dollars)

Project

Program of Citizen Security

Amount

132.4


IV. Statistical Issues ${ }^{1}$

As of May 9, 2011

\begin{abstract}
I. Assessment of Data Adequacy for Surveillance
General: Data provision is broadly adequate for surveillance, although it has some shortcomings in the areas of national accounts, price, government finance and balance of payments statistics.
\end{abstract}

National Accounts: National accounts are compiled generally in accordance with the System of National Accounts 1993 (SNA 1993). However, the reference year for the series at constant prices (1991) is outdated. Estimation of rentals for owner occupied dwellings should be improved. Accounting depreciation is used instead of estimating consumption of fixed capital. Double deflation method is not applied. Changes in inventories are obtained as residuals and the Chow Lin (without indicator) method is applied for benchmarking quarterly value added of activities, comprising a third of GDP. Non-observed/informal activities are not properly covered.

Price Statistics: The compilation of the consumer price index (CPI), in general, employs concepts and definitions from the 1993 SNA and the international CPI manual. However, the CPI lacks a market basket component to measure the cost of owner-occupied housing. Also, the index only covers urban households located in greater San Jose, which comprises approximately 46 percent of the total population and 72 percent of the urban population of Costa Rica. Individual price index data are not generally verified against similar data from other databases such as the producer price index (PPI) and agricultural price indices. Nevertheless, atypical movements in the data are investigated and corrected when necessary.

Except for being compiled only by product aggregations and not by economic activity as well, the PPI is compiled based on concepts and definitions from the 1993 SNA and the international PPI Manual. However, the weights, the establishment sample, and the product sample for the PPI that were introduced in 2000 are based on 1997 sales data. Therefore, the index needs updating. A comprehensive assessment of the source data is being carried out, and is guiding the production of new source data to update the PPI and the national accounts. It is expected that the index will be updated in 2011.

Government Finance Statistics: The concepts and definitions used in compiling GFS generally follow the guidelines of the GFSM 1986. However, financing data and government debt, which use national concepts that combine instruments and holders, are not in accordance with international standards. A migration path to the GFSM 2001 has been adopted in the context of the GFS harmonization project for Central America, Panama, and the Dominican Republic. Monthly fiscal statistics are only compiled and

\footnotetext{
${ }^{1}$ Incorporates the assessment of Costa Rica's macroeconomic statistics provided by the Report on the Observance of Standards and Codes (ROSC) published in February 2010.
} 
disseminated for budgetary central government, while annual statistics are compiled and disseminated for the entire public sector and its subsectors. The place of issue (Costa Rica or abroad) criterion is followed to classify domestic and foreign debt, instead of the internationally recommended residency criterion. Fiscal data discrepancies among national compilers on particular items are not regularly reconciled, although large fluctuations or discrepancies are investigated. Fiscal statistics are not regularly reconciled with monetary statistics, or other macroeconomic statistics.

Monetary Statistics: Costa Rica's monetary statistics are broadly in line with the methodology of the MFSM. Classification/sectorization follows the MFSM with some exceptions. The social security system accounts are not presented within the central government, but aggregated with other public sector accounts. Some financial assets and liabilities are not disaggregated by economic sector. Accrued interest is not classified together with its underlying instrument.

Balance of Payments: The balance of payments statistics broadly follow the concepts and definitions in the BPM5. While generally adequate and derived from sound collection programs, source data are incomplete to compile some services in the current account, financial transactions of the nonfinancial private sector, and remuneration of employees. Foreign direct investment transactions and positions are valued on a cash basis instead of the recommended accrual basis. Services are recorded at the time the service is provided. While other income transactions are recorded on an accrual basis, interest on public external debt is recorded on the due date; no adjustment is made to convert interest to accrued values. Transfer prices in some cases are not converted to market prices.

\section{Data Standards and Quality}

Costa Rica is in observance with the Special Data Dissemination Standards Data Module Report on the Observance of (SDDS). Standards and Codes (ROSC) was published in February 2010. 
Table of Common Indicators Required for Surveillance (As of April 19, 2011)

\begin{tabular}{|c|c|c|c|c|c|c|c|}
\hline & \multirow{2}{*}{$\begin{array}{c}\text { Date of } \\
\text { latest } \\
\text { observation }\end{array}$} & \multirow{2}{*}{$\begin{array}{l}\text { Date } \\
\text { received }\end{array}$} & \multirow{2}{*}{$\begin{array}{l}\text { Frequency } \\
\text { of Data }^{6}\end{array}$} & \multirow{2}{*}{$\begin{array}{l}\text { Frequency } \\
\quad \text { of } \\
\text { Reporting }^{6}\end{array}$} & \multirow{2}{*}{$\begin{array}{l}\text { Frequency } \\
\text { of } \\
\text { Publication }\end{array}$} & \multicolumn{2}{|c|}{ Memo Items: } \\
\hline & & & & & & $\begin{array}{l}\text { Data Quality - } \\
\text { Methodological } \\
\text { soundness }\end{array}$ & $\begin{array}{l}\text { Data Quality - } \\
\text { Accuracy and } \\
\text { reliability }\end{array}$ \\
\hline Exchange Rates & Apr 11 & Apr 11 & $\mathrm{D}$ & $\mathrm{D}$ & $\mathrm{D}$ & & \\
\hline $\begin{array}{l}\text { International Reserve Assets and Reserve Liabilities } \\
\text { of the Monetary Authorities }{ }^{1}\end{array}$ & Apr 11 & Apr 11 & $\mathrm{D}$ & $\mathrm{D}$ & D & & \\
\hline Reserve/Base Money & Mar 11 & Apr 11 & $\mathrm{D}$ & $\mathrm{D}$ & $\mathrm{D}$ & \multirow[t]{4}{*}{ O, LO, LO, LO } & \multirow[t]{4}{*}{$\mathrm{O}, \mathrm{O}, \mathrm{O}, \mathrm{LO}, \mathrm{O}$} \\
\hline Broad Money & Mar 11 & Apr 11 & M & M & M & & \\
\hline Central Bank Balance Sheet & Feb 11 & Mar 11 & M & M & M & & \\
\hline Consolidated Balance Sheet of the Banking System & Jan 11 & Mar 11 & M & M & M & & \\
\hline Interest Rates ${ }^{2}$ & Apr 11 & Apr 11 & $\mathrm{D}$ & $\mathrm{D}$ & $\mathrm{D}$ & & \\
\hline Consumer Price Index & Mar 11 & Apr 11 & M & M & M & O, LO, O, O & LO, O, LO, LO,O \\
\hline $\begin{array}{l}\text { Revenue, Expenditure, Balance, and Composition of } \\
\text { Financing }{ }^{3} \text { - Central Government }\end{array}$ & Mar 11 & Apr 11 & M & M & M & LO, LNO, LO, LO & LO, O, O, LO, O \\
\hline $\begin{array}{l}\text { Stocks of Central Government and Central } \\
\text { Government-Guaranteed Debt }{ }^{5}\end{array}$ & Jan 11 & Mar 11 & M & M & M & & \\
\hline External Current Account Balance & Dec 10 & Mar 11 & Q & Q & Q & \multirow[t]{2}{*}{ O, LO, O, LO } & \multirow[t]{2}{*}{ LO, O, LO, O, LNO } \\
\hline Exports and Imports of Goods and Services & Dec 10 & Mar 11 & Q & Q & $\mathrm{Q}$ & & \\
\hline GDP/GNP & Dec 10 & Mar 11 & Q & Q & Q & O, LO, LNO, O & LO, O, LNO, O, LO \\
\hline Gross External Debt & Dec 10 & Mar 11 & $\mathrm{Q}$ & Q & Q & & \\
\hline International Investment Position & Dec 10 & Mar 11 & Q & Q & Q & & \\
\hline
\end{tabular}

${ }^{1}$ Includes reserve assets pledged or otherwise encumbered as well as net derivative positions.

${ }^{2}$ Both market-based and officially-determined, including discounts rates, money market rates, rates on treasury bills, notes, and bonds.

${ }^{3}$ Foreign, domestic bank, and domestic nonbank financing.

${ }^{4}$ The general government consists of the central government (budgetary funds, extra budgetary funds, and social security funds) and state and local governments.

${ }^{5}$ Including currency and maturity composition.

${ }^{6}$ Daily (D); weekly (W); monthly (M); quarterly (Q); annually (A); irregular (I); and not available (NA).

${ }^{7}$ Reflects the assessment provided in the data ROSC, published in February, 2010 and based on the findings of the mission that took place in April, 2009, for the dataset corresponding to the variable in each row. The assessment indicates whether international standards concerning concepts and definitions, scope, classification/sectorization, and basis for recording are fully observed (O); largely observed (LO); largely not observed (LNO); not observed (NO); and not available (NA).

${ }^{8}$ Same as footnote 7 , except referring to international standards concerning source data, assessment of source data, statistical techniques, assessment and validation of intermediate data and statistical outputs, and revision studies. 


\section{INTERNATIONAL MONETARY FUND}

EXTERNAL Public Information Notice

Public Information Notice (PIN) No. 11/69

International Monetary Fund

FOR IMMEDIATE RELEASE

$70019^{\text {th }}$ Street, NW

May 31, 2011

Washington, D. C. 20431 USA

\section{IMF Executive Board Concludes 2011 Article IV Consultation with Costa Rica and Ex-Post Evaluation of Exceptional Access under the 2009 Stand-By Arrangement}

On May 25, 2011, the Executive Board of the International Monetary Fund (IMF) concluded the Article IV consultation and Ex-Post Evaluation of Exceptional Access under the 2009 Stand-By Arrangement with Costa Rica. ${ }^{1}$

\section{Background}

Costa Rica's economy weathered the global crisis well and its recovery is firmly underway. Following a 1.3 percent decline in 2009, real Gross Domestic Product (GDP) grew by 4.2 percent in 2010, initially led by a recovery in inventories and public consumption and later by private consumption. Annual inflation increased from 4 percent in 2009 to 4.6 percent at endMarch 2011 (well within the 4-6 percent official target range).

Although the external current account deficit widened in 2010, the surplus in the capital account increased by more, as the private sector deleveraging observed in 2009 ended and net public sector inflows increased. As a result, the overall balance of payments recorded a surplus of 1.5 percent of GDP during the year. This surplus, together with some portfolio rebalancing toward local currency-denominated assets, pushed the colón to the appreciated end of the

\footnotetext{
${ }^{1}$ Under Article IV of the IMF's Articles of Agreement, the IMF holds bilateral discussions with members, usually every year. A staff team visits the country, collects economic and financial information, and discusses with officials the country's economic developments and policies. On return to headquarters, the staff prepares a report, which forms the basis for discussion by the Executive Board. At the conclusion of the discussion, the Managing Director, as Chairman of the Board, summarizes the views of Executive Directors, and this summary is transmitted to the country's authorities. An explanation of any qualifiers used in summings up can be found here: http://www.imf.org/external/np/sec/misc/qualifiers.htm.
} 
exchange rate band in late 2010. In response, the central bank lowered the policy interest rate and launched a program of foreign exchange purchases.

The fiscal deficit continued to widen during 2010. Tax revenues did not recover the levels observed prior to the crisis, and government spending, especially wages and current transfers, continued to increase. As a result, the consolidated public sector deficit rose to 5.5 percent of GDP, from 4 percent in 2009. Public sector debt at end-2010 reached 39.4 percent of GDP.

Financial sector indicators are strong, with adequate levels of liquidity and capitalization. Credit to the private sector remained sluggish in 2010 but began to pick up in 2011. Financial dollarization has resumed a declining trend.

Supported by the global economic recovery and strong inflows of foreign direct investment (FDI), real GDP is projected to grow by 4.3 percent in 2011 and stabilize at 4.5 percent over the medium term. Inflation is projected to rise above 7 percent in 2011 pushed by higher world commodity prices and a one-off impact from the tax reform (assumed to be approved in the second half of 2011), but is expected to fall gradually thereafter. The external current account deficit would increase to 4.8 percent of GDP in 2011 and stabilize at about 5.2 percent of GDP over the medium term, and is expected to be fully financed by FDI and other capital flows.

While the economic outlook is generally positive, some downside risks remain. These stem from the rise in commodity prices and abundant global liquidity, which pose risks for the inflation outlook and for macroeconomic policy more generally, particularly if the exchange rate band is maintained. Risks to the outlook could also arise from a weaker fiscal position, as the authorities' fiscal program would result in a gradual decline in the fiscal deficit and a moderate but steady rise in the public debt ratio.

\section{Executive Board Assessment}

Executive Directors welcomed Costa Rica's economic recovery and its favorable outlook, and stressed the importance of gearing macroeconomic policies toward containing domestic demand pressures. Given the challenges presented by high world commodity prices and significant capital inflows, Directors encouraged the authorities to tighten fiscal policy, move toward a more flexible exchange rate, and pursue a vigilant monetary policy.

Directors stressed the importance of safeguarding fiscal sustainability. They welcomed the tax reform proposal submitted to the Legislative Assembly, underscoring that its approval will be key. Directors supported the authorities' efforts to broaden the tax base and improve the equity of the tax system, as well as the planned actions to strengthen tax administration. Looking ahead, they advised the authorities to pursue a more ambitious medium-term fiscal consolidation strategy to help rebuild fiscal buffers. Directors pointed out that the authorities' 
fiscal program could result in a gradual rise in the public debt ratio, and stressed the need to exercise further expenditure restraint, particularly on current spending.

Directors noted the staff's assessment that the exchange rate appears to be broadly in line with fundamentals. They considered that upgrading the monetary policy framework and completing the transition to an inflation targeting regime should be key priorities. They welcomed the authorities' plans to narrow the corridor for short-term interest rates, and encouraged them to develop an effective communications strategy to address a move away from the exchange rate band and make the inflation target the centerpiece of the monetary policy framework. Directors agreed that recapitalizing the Central Bank is essential to bolstering its credibility.

Directors concurred that the banking system remains sound, and encouraged the authorities to continue strengthening supervision and prudential regulations. They stressed the importance of securing approval of the legislation to enhance consolidated supervision, establish a deposit insurance system, and strengthen the resolution framework. Directors encouraged the authorities to press ahead with implementing the remaining Financial Sector Assessment Program recommendations.

Directors welcomed that the authorities' economic program, supported by the precautionary Stand-By Arrangement of 2009-10, had successfully met its immediate objective of supporting macroeconomic stability at a time of global financial turmoil. At the same time, they noted that the fiscal position had deteriorated, particularly through the enactment of permanent, rather than temporary measures, and that progress in advancing structural reforms was slow during the program period.

Public Information Notices (PINs) form part of the IMF's efforts to promote transparency of the IMF's views and analysis of economic developments and policies. With the consent of the country (or countries) concerned, PINs are issued after Executive Board discussions of Article IV consultations with member countries, of its surveillance of developments at the regional level, of post-program monitoring, and of ex post assessments of member countries with longer-term program engagements. PINs are also issued after Executive Board discussions of general policy matters, unless otherwise decided by the Executive Board in a particular case. 


\section{Costa Rica: Selected Economic Indicators}

\begin{tabular}{|c|c|c|c|c|c|c|}
\hline Per capita GDP (2010, U.S. dollars) & 7,843 & \multicolumn{4}{|c|}{ Unemployment (2010, percent of labor force) } & 7.3 \\
\hline & 4.6 & \multicolumn{4}{|c|}{ Poverty (2009, percent of households) } & 18.5 \\
\hline \multirow[t]{2}{*}{ Life expectancy (2009, years) } & 79.1 & Extreme & verty $(200$ & jercent of & useholds) & 4.2 \\
\hline & 2006 & 2007 & 2008 & 2009 & 2010 & $\frac{\text { Proj. }}{2011}$ \\
\hline & \multicolumn{6}{|c|}{ (Annual percentage change, unless otherwise indicated) } \\
\hline \multicolumn{7}{|l|}{ National Income and Prices } \\
\hline Real GDP growth & 8.8 & 7.9 & 2.7 & -1.3 & 4.2 & 4.3 \\
\hline GDP deflator & 11.0 & 9.4 & 12.4 & 8.2 & 7.8 & 5.8 \\
\hline Consumer prices (end of period) $1 /$ & 9.4 & 10.8 & 13.9 & 4.0 & 5.8 & 7.5 \\
\hline \multicolumn{7}{|l|}{ External Sector } \\
\hline Terms of trade (deterioration -) & -3.1 & -2.8 & -1.1 & 4.9 & 0.8 & -3.1 \\
\hline Real effective exchange rate (eop; depreciation -) & 0.8 & 1.5 & 3.8 & 2.1 & 12.3 & $\ldots$ \\
\hline \multicolumn{7}{|l|}{ Money and Credit } \\
\hline Monetary base & 26.9 & 33.0 & 11.9 & 5.1 & 11.2 & 9.7 \\
\hline Broad money & 23.2 & 17.9 & 16.1 & 9.6 & 1.3 & 12.6 \\
\hline \multirow[t]{2}{*}{ Bank credit to private sector } & 28.5 & 38.3 & 31.8 & 4.5 & 4.4 & 11.7 \\
\hline & \multicolumn{6}{|c|}{ (In percent of GDP) } \\
\hline \multicolumn{7}{|l|}{ Public Finances } \\
\hline Combined public sector primary balance 2/ & 4.4 & 5.0 & 2.8 & -0.9 & -2.7 & -2.4 \\
\hline Combined public sector overall balance 2/ & -0.7 & 1.2 & 0.2 & -4.0 & -5.5 & -5.6 \\
\hline Central government & -1.4 & 0.3 & -0.3 & -3.6 & -5.5 & -5.2 \\
\hline Decentralized government entities & 2.1 & 1.3 & 0.6 & 0.4 & 0.3 & 0.0 \\
\hline Public enterprises (excluding ICE) & -0.1 & 0.3 & 0.0 & 0.0 & 0.2 & 0.0 \\
\hline Central Bank & -1.1 & -0.7 & -0.2 & -0.8 & -0.5 & -0.5 \\
\hline Combined public sector debt (excluding ICE) 2/ & 47.3 & 42.5 & 36.0 & 38.4 & 39.4 & 41.8 \\
\hline Of which: External public debt & 12.0 & 9.7 & 8.6 & 7.2 & 7.1 & 6.7 \\
\hline Combined public sector debt (including ICE) $3 /$ & 50.7 & 45.3 & 39.5 & 42.5 & 42.8 & 45.3 \\
\hline \multicolumn{7}{|l|}{ Savings and Investment } \\
\hline Gross domestic investment & 26.4 & 24.7 & 27.6 & 15.9 & 20.0 & 20.2 \\
\hline Gross national savings & 21.9 & 18.4 & 18.2 & 13.9 & 16.3 & 15.4 \\
\hline \multicolumn{7}{|l|}{ External Sector } \\
\hline Trade balance & -12.1 & -11.3 & -16.8 & -7.0 & -10.0 & -11.6 \\
\hline Current account balance & -4.5 & -6.3 & -9.3 & -2.0 & -3.6 & -4.8 \\
\hline \multirow[t]{2}{*}{ Foreign direct investment } & 6.1 & 6.2 & 6.9 & 4.6 & 4.1 & 4.6 \\
\hline & \multicolumn{6}{|c|}{ (In millions of U.S. dollars, unless otherwise indicated) } \\
\hline Change in net international reserves (increase -) & -802 & -999 & 315 & -268 & -561 & -400 \\
\hline Net international reserves & 3,115 & 4,114 & 3,799 & 4,066 & 4,627 & 5,027 \\
\hline In months of nonmaquila imports of G\&S & 3.5 & 3.8 & 4.7 & 4.0 & 4.2 & 4.1 \\
\hline Gross domestic product & 22,526 & 26,322 & 29,838 & 29,241 & 35,780 & 40,167 \\
\hline
\end{tabular}

Sources: Central Bank of Costa Rica; Ministry of Finance; and IMF staff projections.

$1 /$ The projection for 2011 includes a one-off impact from the tax reform (assumed to be approved later in 2011).

2/Combined public sector comprises: the central government, the central bank, decentralized government entities, public enterprises, excluding the Instituto de Electricidad (ICE).

3 / Includes the debt by the Instituto de Electricidad (ICE) guaranteed by the government. 
Press Release No. 11/134

International Monetary Fund

FOR IMMEDIATE RELEASE

Washington, D.C. 20431 USA

April 13, 2011

\section{Staff Statement at the Conclusion of an IMF Mission to Costa Rica}

An IMF mission visited San José during March 28-April 12 as part of the 2011

Article IV consultation discussions with Costa Rica. The mission met with Vice President Luis Liberman, Minister of Finance Fernando Herrero, Central Bank President Rodrigo Bolaños, other senior officials, members of congress, academics and representatives of the private sector. At the end of the visit, Marco Piñón, chief of the IMF mission, issued the following statement:

"Economic activity in Costa Rica recovered in 2010 led by private consumption, while inflation remained within the official target range. With the normalization of external trade, the current account deficit widened, but was comfortably financed by large foreign direct investment (FDI) and other private capital inflows. Reflecting this, the exchange rate appreciated and moved to the limit of the exchange rate band, despite significant foreign exchange intervention. In addition, the deficit of the combined public sector increased to 5.5 percent of Gross Domestic Product (GDP), owing to subdued tax revenues and higher government expenditures.

"The medium-term economic outlook for Costa Rica is broadly positive, underpinned by the global recovery and robust FDI inflows. Real GDP growth is expected to hover around 4-4.5 percent in 2011 and over the medium term, while inflation is projected to increase in 2011, pushed by higher global food and fuel prices, but to decline in subsequent years. FDI and other private capital flows are likely to remain strong.

"Near term risks are mainly related to a higher than expected impact of international food and fuel prices on inflation. In the medium and long term, the key challenge is to lower the fiscal deficit significantly. In this regard the mission considers that the draft tax reform recently sent to Congress is key to secure a higher revenue base that increases the country's capacity to respond to adverse shocks. However, efforts on the revenue side will need to be supplemented by prudent expenditure policies, including through a medium-term framework to help reduce the share of current government spending over GDP.

"The mission encouraged the authorities to continue strengthening the monetary policy and financial supervision frameworks. Approval of bills before Congress aimed at enhancing 
consolidated supervision, establishing a deposit insurance system, and strengthening the banking resolution framework would help bring Costa Rica's financial regulation in line with best international practices, and to protect the stability of the financial system.

"The IMF will continue its close policy dialogue with the authorities of Costa Rica. Upon its return to Washington, staff will prepare a report to the IMF's Executive Board, which will serve as a basis for a Board discussion in late May." 


\section{Statement by Mr. Perez-Verdia and Mr. Gramajo-Marroquin on Costa Rica Executive Board Meeting May 25, 2011}

We would like to thank staff for their comprehensive set of papers and for the constructive dialogue with our authorities. We broadly agree with staff's assessment and recommendations.

\section{Ex Post Evaluation of Exceptional Access Under the 2009 Stand-By Arrangement.}

1. Although we cannot evaluate outcomes had a program not been in place, we can ascertain that the program was successful in helping the country maintain confidence in the government's response to the crisis by increasing existing liquidity buffers. In this context, we believe the program helped Costa Rica take advantage of its strong fundamentals to mitigate the adverse effects stemming from the global crisis and preserve financial stability.

2. The policy mix during the crisis was adequate. A tighter monetary stance and an expansionary fiscal policy (using fiscal spaces created before the crisis) helped Costa Rica face the economic slowdown while safeguarding confidence. As a result, external risks did not materialize and the economy began to recover quickly after the crisis. We reiterate our view that IMF support during program discussions and the length of the SBA was instrumental to face this period successfully.

3. Ex post evaluation of the quality of the stimulus package is always likely to reveal weaknesses, but the nature and size of the stimulus package, like in other countries, reflected operational constraints given the very immediate nature of the challenge. Fiscal deterioration at the time was mainly driven by lower-than-envisaged tax collections. We believe that the greatest uncertainty during this period was about the duration and severity of the crisis and whether the drop in tax collections was permanent or temporary.

4. Our authorities made efforts to improve monetary policy effectiveness, although the transition toward inflation targeting did not accelerate. In particular, as staff rightly pointed out, the single rate crawling peg was replaced by a crawling band, open market operations were streamlined, the Central Bank established an overnight lending facility (which was recently complemented with a deposit facility), and a draft law to recapitalize the BCCR was submitted to Congress. 
5. We think that streamlined conditionality in HAPAs allows member countries to achieve short-term goals more effectively. We have no doubt that Costa Rica's 2009 SBA helped withstand the crisis better than a traditional SBA by providing substantial liquidity buffers thereby effectively insuring the country against external risks. Moreover, there is evidence of the success of the program: the SBA remained precautionary and on track and the financial system stayed strong with ample liquidity throughout.

6. In sum, taking into account the high level of uncertainty during the crisis, we believe that the modality, design and implementation of the program, were adequate to guarantee its success.

\section{Article IV Consultation}

\section{Recent Developments}

After a 1.3 percent decline in 2009, Costa Rica's economy grew 4.2 percent in 2010 and is expected to grow 4.3 percent in 2011.

Inflation increased to 5.8 percent in 2010, within the 4-6 target range. Although inflation decreased to 4.7 percent at end-April 2011, significant risks stem from increases in international food and fuel prices, which have recently increased inflation expectations and put at risk the Central Bank's 2011 inflation target.

As staff pointed out, domestic currency appreciation pressures continue due mainly to higher private capital inflows and some portfolio rebalancing toward domestic currency denominated assets.

The current account deficit was 3.6 percent of GDP in 2010, which was more than compensated by the surplus in the capital account due to private capital inflows. Hence, the overall balance of payments showed a surplus of more than 1.5 percent of GDP.

The banking sector remains liquid and well capitalized, and nonperforming loans have stabilized below 2 percent of total loans.

\section{Fiscal Policy}

The consolidated public sector deficit for 2011 is projected at 5.6 percent (similar to fiscal outturn for 2010: 5.5 percent). According to staff's view, fiscal outturn is still expansionary, given the strong domestic demand. Our authorities are taking measures this year, such as freezing employment levels in central administration and reducing operational expenditures below margins contemplated in the budget, which should generate some savings.

Nevertheless, room for further current expenditure reductions is limited, given existing rigidities of public expenditures.

Our authorities understand the importance of stabilizing public sector debt at prudent levels. They presented in January their National Fiscal Sustainability Policy, a comprehensive 
strategy with the aim of increasing tax revenues and controlling current spending over the medium term. It contemplates a comprehensive tax reform and tax administration measures, which authorities expect will yield 2.5 percent of GDP and 1 percent of GDP, respectively. Our authorities believe that there is significant room to improve tax administration, in particular by reducing tax evasion. In this sense, they are in the process of adopting a new information system that would enhance information crosschecks and tax compliance controls. They are also taking measures to control current expenditure in the short and medium terms.

We believe that the proposed tax reform, submitted in January, will increase efficiency and enhance equity by eliminating current distortions in the tax system. It modernizes the sales tax, bringing it more in line with international VAT practices and broadening its base to include services. While broadening the VAT base, our authorities have protected the most vulnerable by exempting from the VAT a small consumption basket, basic electricity and water consumption, as well as some private schools. On income taxes, the tax reform levels the playing field on capital income by proposing a single tax rate of 15 percent on dividends, capital gains, and interest income.

Our authorities are aware that achieving their ambitious fiscal strategy is challenging, but remain confident that it will bring about significant fiscal consolidation with the stabilization of Costa Rica's public debt. In the short term, the strategy is expected to reduce the deficit by about 0.5 percent of GDP in 2011 due to the combination of tax administration improvements and expenditure cuts. Furthermore, our authorities stand ready to make further efforts on the expenditure side should it become necessary.

\section{Monetary and Exchange Rate Policies}

Our authorities remain committed to maintaining low and stable inflation. They kept the 4-6 percent target range for 2011 and have adopted measures to enhance monetary management, including the establishment of a deposit facility that, jointly with the lending facility, generated a corridor for short-term interest rates, and introduced new instruments to neutralize excess liquidity.

Increases in international food and fuel prices and relaxed global financial conditions pose significant risks to inflation in 2011. In this context, our authorities are willing to tighten the monetary policy stance as soon as signs of second-round effects are evident.

In line with their inflation objective, authorities share the view that a more flexible exchange rate would help anchor inflation expectations, and they convey their intention to eliminate the exchange rate band before the adoption of a full-fledged inflation targeting regime. However, they consider the current economic environment inappropriate for such shift in the exchange rate regime. In particular, currently high global liquidity and a significant shift in the portfolio of Costa Rican residents toward local currency_-denominated assets are seen as temporary factors pressing the exchange rate against the most appreciated side of the band. A more flexible exchange rate regime would lead to further appreciation-on top of a 14 percent real appreciation already observed since April 2009 — that might very well revert once liquidity conditions normalize in advanced countries. 


\section{Financial Sector}

The financial system weathered the global crisis well, but we acknowledge that further progress on improving financial legislation is warranted, particularly to enhance consolidated supervision and strengthen the bank resolution framework. In this context, our authorities are committed to seek approval from the National Assembly of the related draft laws.

Meanwhile, they are working to introduce risk-base supervision and are planning to monitor system risk and introduce Base III capital and liquidity buffers. Our authorities are of the view that advances in the adoption of main recommendations of the 2008 FSAP update are greater than reported by the staff (Box 3). 